\title{
MASTER
}

\section{Study of Hydrogen-Powered versus Battery-Powered Automobiles}

\author{
Volume I
}

Prepared by

J. J. DONNELLY, JR., W. J. D. ESCHER, W. C. GREAYER, and R. J. NICHOLS

Eastern Technical Division

May 1979

Prepared for

U.S. DEPARTMENT OF ENERGY

Alternative Fuels Branch

Office of Transportation Programs

Washington, D.C. 20545

Contract No. EM-78-C-03-2184

Government Support Operations

The Aerospace Corporation 


\section{DISCLAIMER}

This report was prepared as an account of work sponsored by an agency of the United States Government. Neither the United States Government nor any agency Thereof, nor any of their employees, makes any warranty, express or implied, or assumes any legal liability or responsibility for the accuracy, completeness, or usefulness of any information, apparatus, product, or process disclosed, or represents that its use would not infringe privately owned rights. Reference herein to any specific commercial product, process, or service by trade name, trademark, manufacturer, or otherwise does not necessarily constitute or imply its endorsement, recommendation, or favoring by the United States Government or any agency thereof. The views and opinions of authors expressed herein do not necessarily state or reflect those of the United States Government or any agency thereof. 


\section{DISCLAIMER}

Portions of this document may be illegible in electronic image products. Images are produced from the best available original document. 
STUDY OF HYDROGEN-POWERED

VERSUS BATTERY -POWERED AUTOMOBILES

\author{
Prepared by
}

J. J. Donnelly, Jr., W. C. Greayer, and R. J. Nichols

Energy Conservation Directorate

and

W. J. D. Escher

Escher Technology Associates

May 1979

Government Support Operations

Eastern Technical Division

THE AEROSPACE CORPORATION

E1 Segundo, California 90245

Prepared for

U.S. DEPARTMENT OF ENERGY

Alternative Fuels Branch

Office of Transportation Programs

Conservation and Solar Applications

Washington, D. C. 20545

DOE Project Monitor: E. E. Ecklund

Contract No. EM-78-C-03-2184 
THIS PAGE

\section{WAS INTENTIONALLY \\ LEFT BLANK}




\section{PREFACE}

This report, prepared by The Aerospace Corporation for the Department of Energy, Office of Transportation Programs, documents the study conducted to compare the technological status and the resultant potential velicle characteristics for hydrogen- and battery-powered automobiles that could be produced from 1985 to 2000. The primary objectives of the study were: (1) the assessments of applicable energy storage and propulsion technology for the two basic vehicle types (applied to four-passenger cars), (2) a rigorous comparison of vehicle weight, size, and usefulness versus design range, and (3) an investigation of the relative efficiencies of expending energy from various primary sources to power the subject vehicles. Another important objective, unique to hydrogen-powered vehicles, was the assessment of the technology, logistics, and cost implications of a hydrogen production and delivery capability.

The information contained in the technology assessments was obtained by a review of the literature available up to mid-1977 and by personal contacts with government, university, and industry researchers. This report is organized in three volumes. This volume, Volume I, provides a summary of study scope, methodology, results, and conclusions relative to the principal propulsion options considered for the 1985, 1990, and 2000 model years.

Volume II provides an introduction to the study and two major sections applicable to. hydrogen-powered vehicles - the study of hydrogen production and delivery alternatives before the year 2000 and the assessment of automotive technology for hydrogen storage and use in internal combustion engines.

Volume III contains three major sections: the assessment of battery electric vehicle technology for energy storage and the drivetrain system; the technical and economic comparison of hydrogen- and 
battery-powered vehicles derived primarily from data in the previous vehicle technology assessments, with consideration of alternative energy sources; and a series of appendices that support the vehicle definitions and comparisons. 


\section{ACKNOW LEDGMENTS}

Appreciation is acknowledged for the assistance and guidance provided by Mr. Eugene E. Ecklund, Chief, Alternative Fuels Branch, Office of Transportation Programs, Department of Energy, who served as program monitor. The cooperation and information provided by many staff members in government agencies, industry, and the academic community are also gratefully acknowledged.

Listed below are the technical personnel of The Aerospace Corporation and the principal consultant of Escher Technology Associates, St. Johns, Michigan, who were responsible for the study performed under this contract:

$$
\begin{aligned}
& \text { J. J. Donnelly, Jr. } \\
& \text { W. C. Greayer } \\
& \text { R. J. Nichols } \\
& \text { W. J. D. Escher }
\end{aligned}
$$

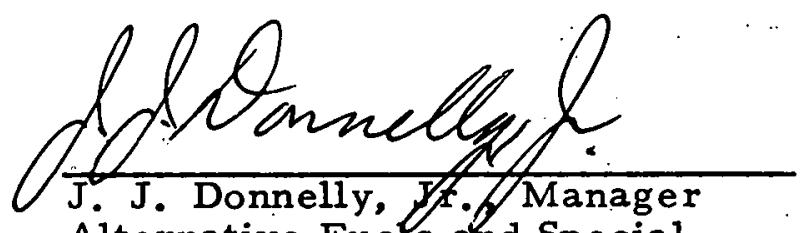

Alternative Fuels and Special Projects Energy Conservation Directorate

Approved by:

ifit. Rerankr W. U. Roessler, Systems Director Energy Conservation Directorate Eastern Technical Division

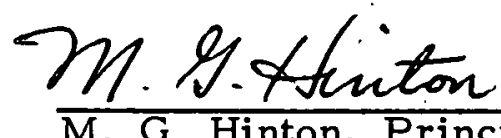

M. G. Hinton, Principal Director Mobile Systems Directorate Eastern Technical Division

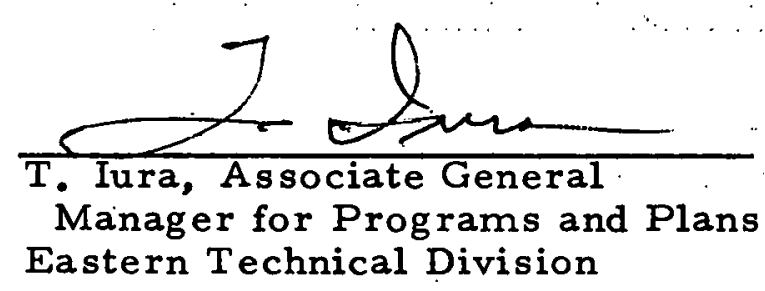




\section{THIS PAGE \\ WAS INTENTIONALLY \\ LEFT BLANK}


FOREWORD

This report, prepared by The Aerospace Corporation for the Department of Energy, Office of Transportation Programs, documents the study conducted to compare the technological status and the resultant potential vehicle characteristics for hydrogen- and battery-powered automobiles that could be produced from 1985 to 2000 . Both vehicle types potentially afford operation independent of petroleum and natural gas fuel supplies with concomitant sharp reductions in vehicle exhaust emissions. The primary objectives of the study were: (1) the assessments of applicable energy storage and propulsion technology for the two basic vehicle types (applied to four-passenger cars), (2) a rigorous comparison of vehicle weight, size, and usefulness versus design range, and (3) an investigation of the relative efficiencies of expending energy from various primary sources to power the subject vehicles. Another important objective, unique to hydrogen-powered vehicles, was the assessment of the technology, logistics, and cost implications of a hydrogen production and delivery capability. Secondary objectives included evaluation of the total costs of vehicle ownership and identification of potential safety problems.

In the interest of limiting study scope, certain restrictions in propulsion system configuration were adopted. Hydrogen engines were sparkignited, internal combustion engines with appropriate modifications depending upon the energy storage options. Electric vehicle powertrains were direct current systems fed by a single battery type, appropriate to each time period (no dual batteries), without flywheels or other secondary energy storage or propulsion provisions.

The information contained in the technology assessments was obtained by a review of the literature available up to mid-1977 and by personal contacts with government, university, and industry researchers. 


\section{WES THIS PAGE HL: WASINTENTIONALLY LEFT BLANK}




\section{ABSTRACT}

A study has been conducted of two future candidate automobile propulsion systems that do not rely upon petroleum or natural gas as an energy source. Potential vehicle characteristics for each system have been identified. The first vehicle system employs a gaseous, hydrogen-fueled, interial combustion engine and either a liquid or metal hydride energy storage system. The second vehicle system employs an electronically controlled, electric motor powertrain and a battery energy storage system. Major tasks included in this study were the technical and economic assessments of the state of the art and future alternatives in hydrogen production and delivery, the hydrogen vehicle assessment, the battery-electric vehicle assessment, and the comparison of the principal vehicle alternative in 1985 , 1990, and 2000. The comparison includes weight, size, cost, energy, and design range relationships and the implications on expenditure of all major energy sources.

The study is summarized, results are presented, and conclusions are drawn. Comments are made on the future roles of hydrogen and electricity in automobile propulsion. 


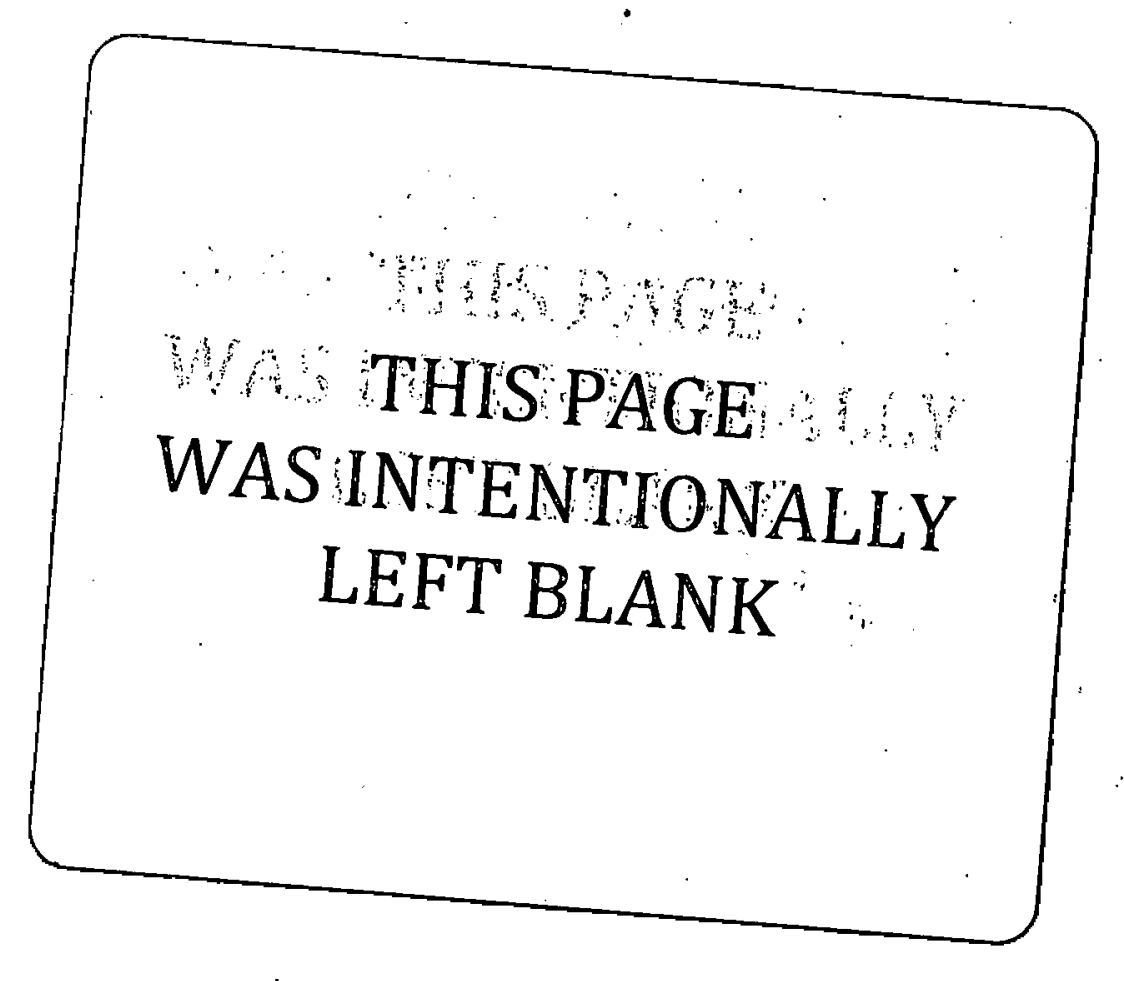




\section{CONTENTS}

VOLUME I

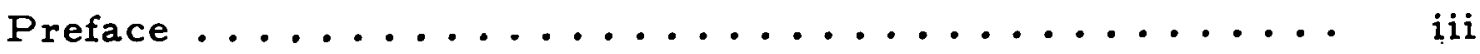

Acknowledgments ....................... v

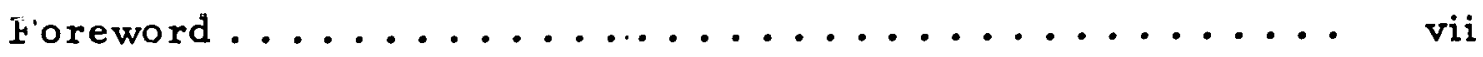

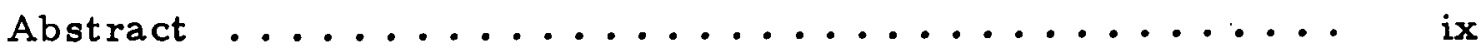

Executive Summary ....................... 1

VOLUME II

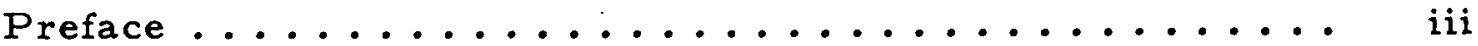

Acknowledgments ..................... v v

Section 1. Introduction ....................... 1-1

Section 2. Hydrogen Production and Delivery ........ $2-1$

Section 3. Hydrogen Vehicle Assessment ............ 3-1

VOLUME III

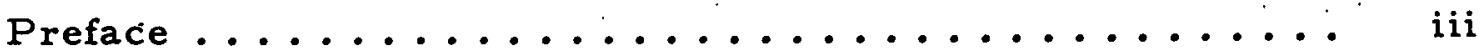

Acknowledgments ......................... v

Section 4. Electric Vehicle Assessment .......... 4-1

Section 5. Technical and Economic Comparison of

Hydrogen - and Battery-Powered Vehicles .... 5-1

Appendix A. Driving Cycle Analysis of Losses and

Horsepower Requirements ..............

Appendix B. Electric Vehicle Range Estimation ........ B-1

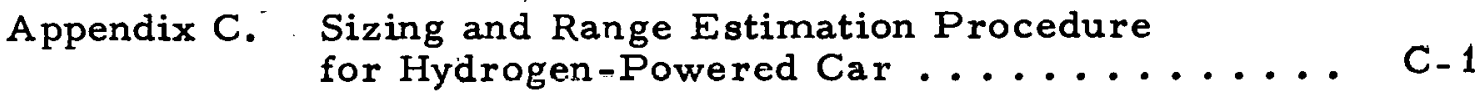

Appendix D. Weight of Battery-Powered Car ........ D-1

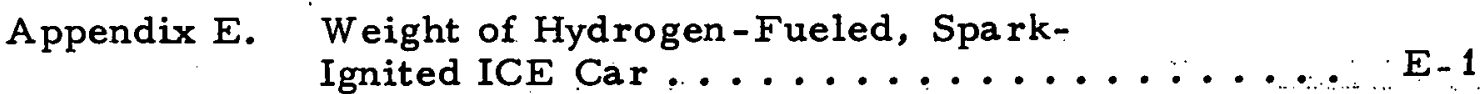

Appendix F. Unit Conversion Factors ............ F-1

Appendix G. Visits and Contacts ............... G-1

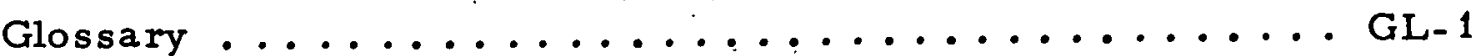




\section{THIS PAGE WAS INTENTIONALLY \\ LEFT BLANK}


PREFACE $\ldots \ldots \ldots \ldots \ldots \ldots \ldots \ldots \ldots \ldots \ldots \ldots \ldots \ldots \ldots \ldots$

ACKNOWLEDGMENTS .................... v

FOREWORD ............................... vii

ABSTRACT......................... ix

EXECUTIVE SUMMARY $\ldots \ldots \ldots \ldots \ldots \ldots \ldots \ldots \ldots \ldots \ldots$

1. INTRODUCTION AND OVERVIEW .............. 1

1.1 Introduction. ..................... 1

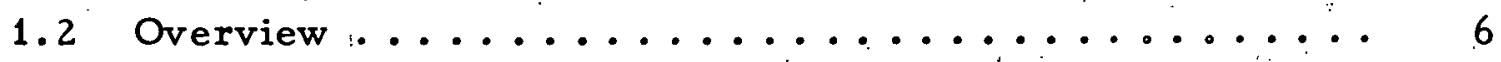

2. HYDROGEN PRÓDUCTION AND DELIVERY ......... 8

2.1 Production .................... 8

2.2 Delivery ....................... 12

3. HYDROGEN VEHICLE ASSESSMENT ............ 13

3.1 Energy Storage ..................... 13

3.2 Engine Characteristics ................... 15

3.3 Safety Hazards..................... 17

4. ELECTRIC VeHICLE ASSESSMENT ............. 18

4.1 Energy Storage $\ldots \ldots \ldots \ldots \ldots \ldots \ldots \ldots \ldots \ldots \ldots$

4.2 Drivetrain Characteristics .............. 23

4.3 Safety Hazards. .................. 27

5. DEFINITION OF VEHICLE CHARACTERISTICS ....... 27

5.1 Driving Cycle Parametric Analysis............ 27

5.2 Hydrogen Vehicle Analyses . . . . . . . . . . 30

5.3 Electric Vehicle Analyses ............... 34

5.4 Comparison of Vehicles. ................... 39 
6. SOURCE ENERGY CONVERSION AND TRANSFER

EFFICIENCIES ...................... 42

7. OVERALL SOURCE ENERGY UTILIZATION. . . . . . ... 47

8. VEHIC LE COMPARISON SUMMARY ............. 51

8.1 Liquid Hydrogen-Fueled ICE Cars............. 51

8.2 Gaseous Hydrogen-Fueled ICE Cars ........... . 54

8.3 Lead/Acid Battery-Powered Car............. 54

8.4 Nickel/Zinc Battery-Powered Car ............ 54

8.5 Zinc/Chlorine Hydrate Battery-Powered Car . . . . . . 54

8.6 Lithium-Aluminum/Iron Sulfide Battery-

Powered Car....................... 54

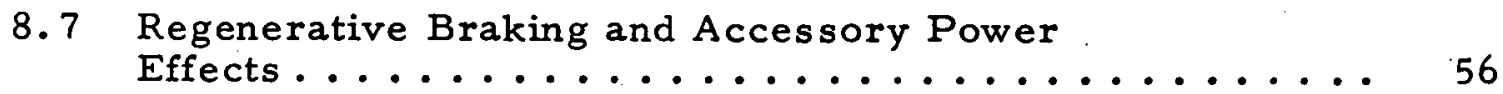

9. CONCLUSIONS.......................... 56

10. REFERENCES ....................... 58 


\section{FIGURES - VOLUME I}

1 Hydrogen Production Cost Versus Coal Cost ........ 10

$2 \quad$ Hydrogen Production Cost Versus Electricity Cost......

3 Automotive Hydrogen Storage System - Low

Tempe rature Hydride .................. 16

4 Automotive Hydrogen Storage System - Convective High

Temperature Hydride Storage Unit .............. 16

5 Ideal Performance Map for Naturally Aspirated, Spark Ignition, Hydrogen-Air Engines (Fuel/Air Otto Cycle) ....

Oxides of Nitrogen, Brake Mean Effective Pressure, and Thermal Efficiency Versus Equivalence Ratio......... 18

$7 \quad$ Zinc/Chlorine Hydrate Battery Schematic ......... 21

8 Sectional View of $30-\mathrm{kWh}$ Lithium-Aluminum/Iron

Sulfide Vehicle Battery .................

9 Power and Energy Densities of Representative Batteries...

Typical Direct Current Traction Motor Efficiencies as a

Function of Design Load and Speed .............

11 Estimated Electric Vehicle Drivetrain Efficiency at

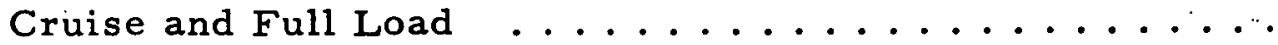

12 Society of Automotive Engineers J227a, Schedule D

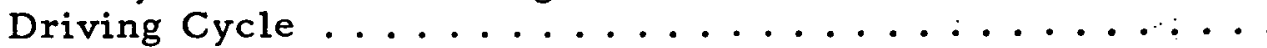

13 Propulsion Energy Requirements of Society of Automotive

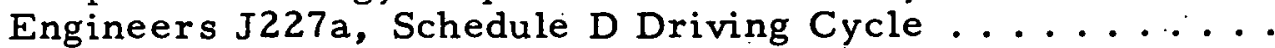

14 Horsepower Requirements of Society of Automotive Engineers J227a; Schedule D Driving Cycle .........

Weight of Hydrogen-Powered Four-Passenger Cars . . . .

161985 Model Year Electric Vehicle Characteristics -

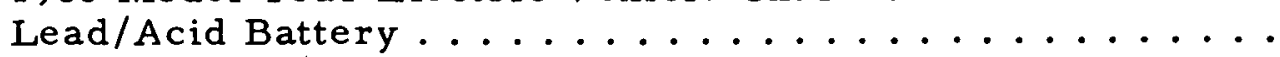




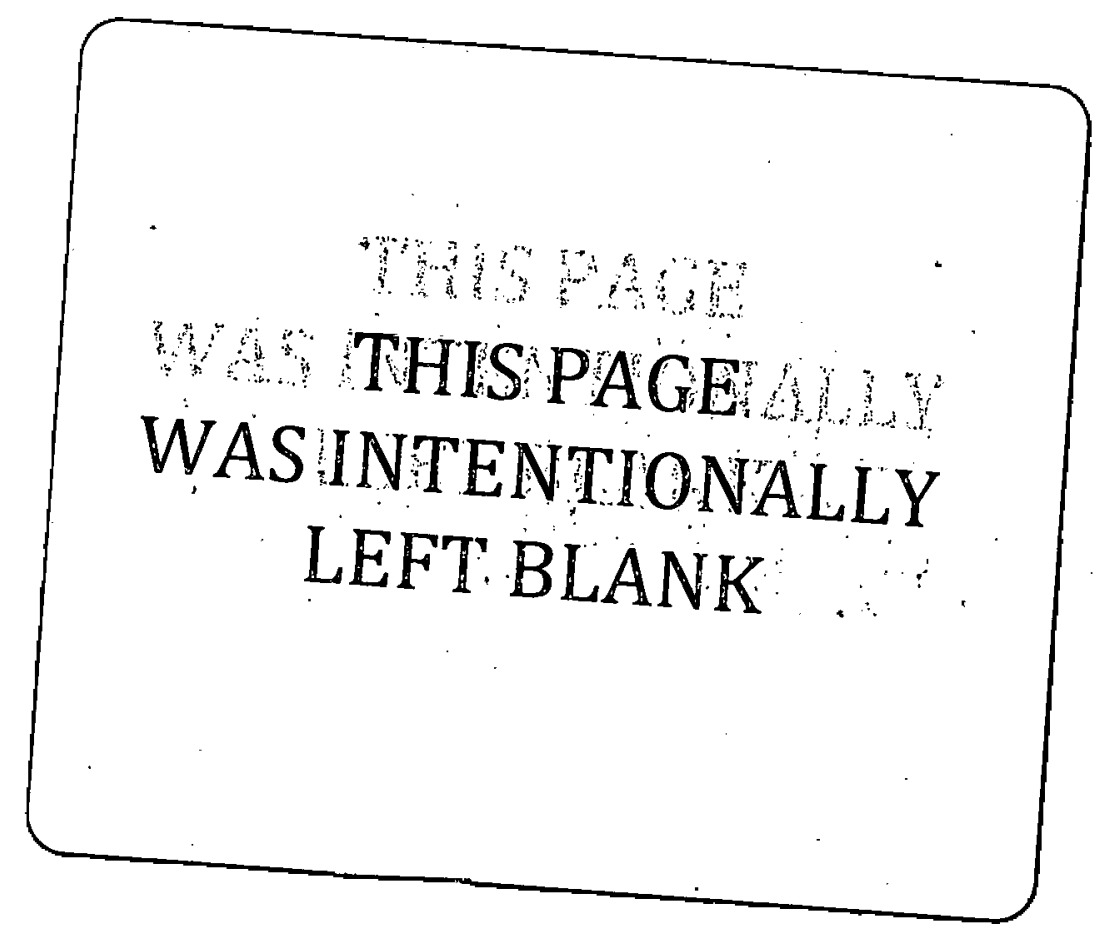




\section{TABLES - VOLUME I}

1 Typical Energy Efficiency Comparison - 1990 Model

Year Cars - Energy Resource: Coal ............. 4

2 Properties of Certain Metal Hydrides ............... 14

3. Principal Problems in Application of Hydrogen to Spark Ignition Engine-Powered Car ............. 19

4. Assumed Automobile Battery Characteristics ......... 22

5. Electric Vehicle Design and Performance Criteria ..... 26

6 Results of Hydrogen Engine Cycle Analyses .......... 31

$7 \quad$ Weight of Engine and Transmission ............. 32

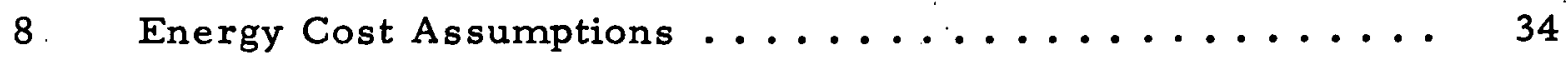

9 Typical Cost Per Mile for Hydrogen-Powered Cars . . . . . 35

10 Summary of Electric Vehicle Design and Performance Characteristics ................ 38

11 Total Cost Per Mile for Batterý-Powered Cars . . . . . . . 40

12 Weights and Costs of Minimum Range Four-Passenger

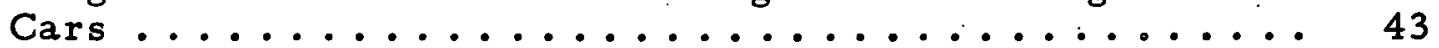

13 Conversion Process Efficiencies.................. 44

14 Energy Transport and Storage Efficiency Assumptions . . . . 45

15. Vehicle Energy Charging Efficiency ............. 46

16 Efficiency of Processes from Energy. Source to Vehicle Energy Storage Input - Energy Source: Coal ......... 48

17 Efficiency of Processes from Energy Source to Vehicle Energy Storage Input - Year $2000 \ldots \ldots \ldots . . . \ldots$

181990 Model Year Vehicle Energy Comparisons Energy Source: Coal .................... 50 


\section{TABLES - VOLUME I (Continued)}

19 Comparison of Overall Source Energy Consumption

Versus Vehicle Type - Minimum Design Range ......... 52

20 Comparison of Key Characteristics of Hydrogen-

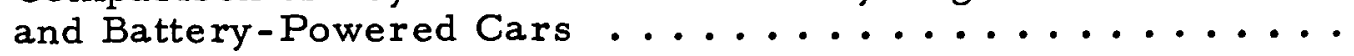




\section{EXECUTIVE SUMMARY}

1.

1.1

INTRODUCTION AND OVERVIEW

\section{INTRODUCTION}

In order to assess the relative attractiveness of hydrogen and electricity in automotive propulsion systems for the 1985 to 2000 period, a cost-benefit study was conducted under the sponsorship of the U.S. Department of Energy (DOE). The generation of hydrogen and electricity from the same sources was considered, and a comparison was made of the use of these energy forms, respectively, as a fuel in spark ignition automobile engines and in battery propulsion systems. The lack of an established merchant hydrogen industry and distribution infrastructure suitable for the transportation sector justified a major effort being focused on hydrogen production and delivery. This effort included consideration of energy and feedstock sources; production processes; conversion efficiencies; costs of capital equipment and products; and the alternative transmission, storage, and distribution modes, and their energy and cost impact.

Technology assessments for hydrogen and battery electric automotive propulsion systems were made with emphasis on the energy storage systems and the operation of hydrogen-fueled, spark ignition engines.

For the hydrogen vehicle, detailed attention was given to the unique problems of spark ignition engine operation and storage of the fuel in cryogenic liquid and metal hydride forms; automotive experience to date with hydrogen was summarized; engine operating problems of flashback, power loss, and oxides of nitrogen ( $\mathrm{NO}_{\mathbf{x}}$ ) emissions were addressed, and the effectiveness of corrective measures was assessed; projections were made for engine efficiency, horsepower per unit displacement, and engine weight and cost; descriptions were provided for near-term iron-titanium hydride and representative advanced magnesium alloy hydride storage systems, including hydride characteristics, system design and integration, tank design, refueling problems, and system cost. Cryogenic storage and feed system topics 
included system design, tank technology, weight, cost, safety, and refueling. The utility of liquid hydrogen and certain metal hydrides as heat sinks for simple automotive air conditioning systems was noted.

Electric vehicles were similarly assessed, starting with consideration of near-term and representative mid-term and advanced batteries. The treatment included battery descriptions and development goals (specific energy, specific power, efficiency, cycle life, installed cost); technology of drive motors, controllers, and other components; auxiliary power requirements; driving cycles; projections of aerodynamic and rolling resistance characteristics; regenerative braking; material, manufacturing, maintenance, safety, and environmental factors; and cost of ownership. Vehicle performance criteria were established, and values of propulsion and vehicle resistance parameters were selected for 1985, 1990, and 2000 for the subsequent com-. parisons with hydrogen-fueled vehicles.

In this report, a hydrogen-powered vehicle employing an internal combustion engine (ICE) is referred to as a HV. If the vehicle is fueled with liquid hydrogen and stores the hydrogen in this form, it is designated as a liquid storage hydrogen vehicle (LSHV). If the vehicle is fueled with gaseous hydrogen and stores the hydrogen in hydride form, it is designated as a gaseous storage hydrogen vehicle (GSHV). The battery-powered electric vehicle is given the familiar designation $\mathrm{EV}$ and excludes options such as hybrids, fuel cells, flywheels, and inductive systems.

The final major task in the study was the comparison of HV's and EV's. Overall energy efficiency comparisons were first made considering alternative fossil and nonfossil sources; conversion to gaseous or liquid hydrogen and electricity; transmission, storage, and distribution by various modes; and charging into vehicle hydrogen tanks or batteries. Analyses of vehicle weight, size, and cost were then made using comparable parametric performance criteria for HV's and EV's. Even in their more advanced designs, these vehicles are decidedly more range- and performance-constrained than conventionally fueled cars. Consequently, design range, on a selected 
driving cycle, was varied to accommodate tradeoffs between vehicle usefulness, weight, performance, and cost of ownership. Sensitivity analyses included the effects of auxiliary power loads, regenerative braking recovery factors, and aerodynamic drag characteristics. Vehicle energy consumption characteristics were then combined with the previous energy source analyses to yield the overall efficiency from source through propulsion mission.

Emphasis in this study was on defining weight, size, range, and energy consumption characteristics for vehicles capable of approximately the same minimum missions. Although included in vehicle definition, cost estimates are definitely less significant than other characteristics. This is because cost's are sensitive to the technical uncertainties of the vehicles in addition to the imponderable movements in energy and material availability, and to prices dependent upon technology, economics, and political forces for the remainder of the century.

This report is a summary of the study's methodology and results. Conclusions are presented, and comments made on the future roles of hydrogen and electricity in automobile propulsion.

The results of this type of study cannot adequately be summarized in a few pages prior to the detailed presentation of study assumptions and methodology. However, to provide a preview of the results of some important technical comparisons of vehicle alternatives and their associated energy supply systems, the following discussion is provided.

In Table 1, illustrative study results for vehicle weight and energy consumption characteristics are presented for representative 1990. model year cars of minimum practical range. Coal is the energy resource assumed for evaluation of the overall energy impact of the different vehicle propulsion concepts.

The heavy zinc/chlorine hydrate EV--designed to a longer range than the HV because of its estimated cycle life and the 100,000-mi lifetime mileage requirement--is seen to have the highest road load energy requirement. However, the relatively efficient powertrain of this car results 
TABLE 1. TYPICAL ENERGY EFFICIËNCY COMPARISON - 1990 MODEL YEAR CARS - ENERGY RESOURCE: COAL

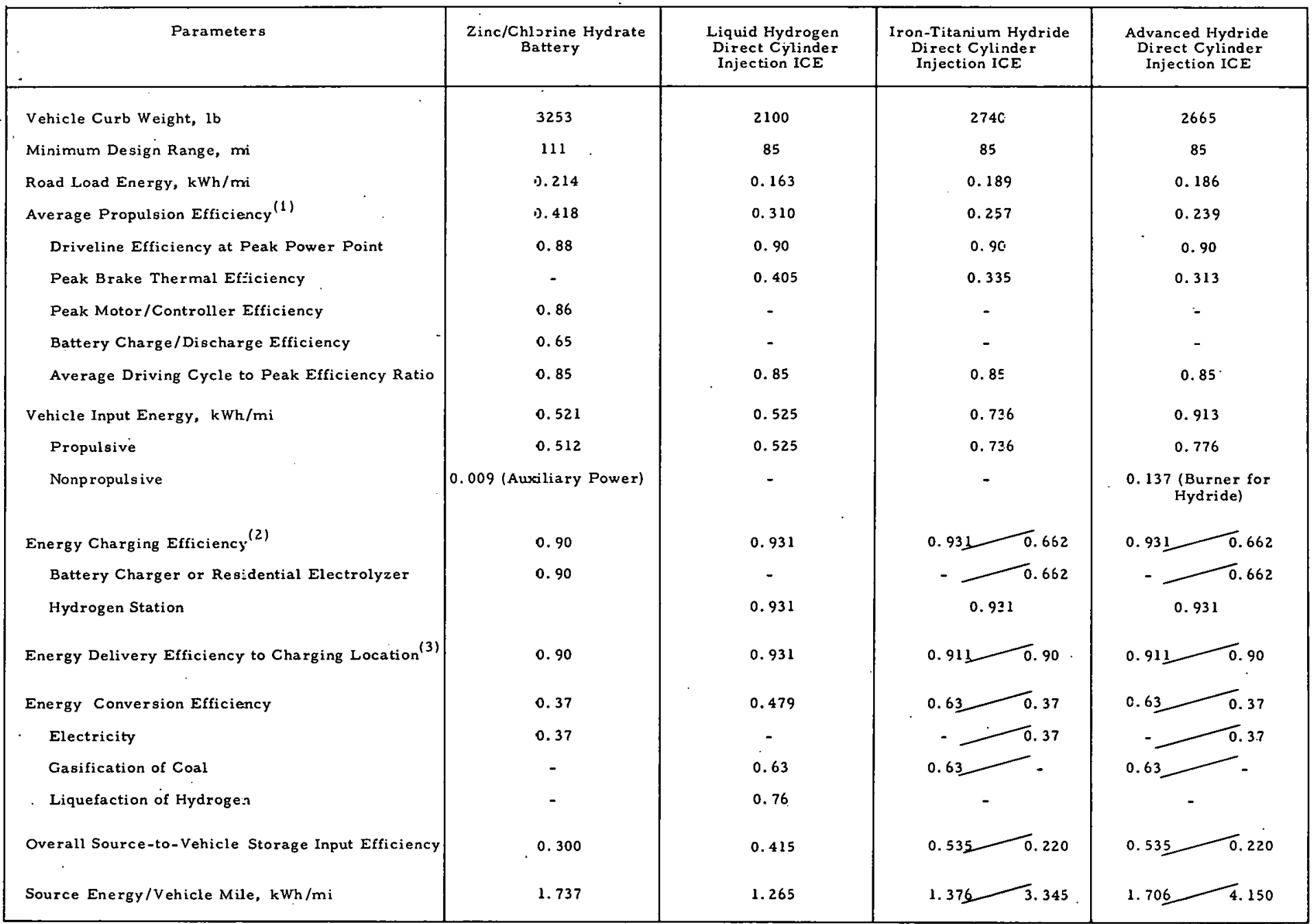

(1) Road load energy divided by hydrogen or electrical energy consumed.

(2) Hydrogen delivery Residential clectrolyzer .

${ }^{(3)}$ Nonessential energy storage neglected. 
in its having the lowest vehicle input energy per mile. The EV must be supported by a relatively inefficient energy conversion and delivery system and, consequently, it consumes more coal resource energy per vehicle mile than any practical $\mathrm{HV}$ option.

Among the HV's--all of which are assumed to utilize direct cylinder injection of 1000-psi hydrogen gas--the one that stores its fuel in liquid form has distinct advantages in vehicle weight, road load, propulsion efficiency and, hence, vehicle input energy per mile. Even with the addition of an inefficient liquefaction step, the LSHV makes the best use of coal resources for all vehicles considered.

The HV featuring an advanced magnesium-nickel alloy hydride storage system is estimated to weigh less than one utilizing a more conventional iron-titanium hydride; however, the propulsion efficiency suffers, primarily because of the greater work required for hydrogen compression. A more significant loss results from the need to burn about 15 percent of the hydrogen to supply high temperature heat for dissociation of the more hydrogenrich hydride. Through use of a residential electrolyzer to produce hydrogen for on-board hydride energy storage systems, dependence upon development of a costly hydrogen infrastructure is avoided, but at a severe penalty in the effective use of coal resources.

Gasoline-powered cars were not considered as an option in this study, but some approximate comparisons can be made with the vehicles studied by using existing weight and fuel economy projections. The current federal procedures for determining composite city/highway fuel economy are vastly different from the simplified analysis permitted by the:J227a, Schedule D driving cycle defined by the Society of Automotive Engineers, which is used in this study. With this difference in mind, as well as the fact that all gasoline vehicles have higher accelerations and much longer design ranges (on a full tank of fuel) than the HV's and EV's studied, the following average characteristics for a 1978 model, subcompact, gasoline-fueled ICE car can be used: curb weight $=2486 \mathrm{lb} ;$ range $\approx 300 \mathrm{mi}$; fuel economy $=25 \mathrm{mpg}$; peak brake thermal efficiency $=0.30$. 
The fuel economy figure translates to $1.57 \mathrm{kWh} / \mathrm{mi}$ input energy to the fuel tank, which is three times as high as that calculated for the 1990 model year LSHV. Improvements in the gasoline car by 1990 should result in a curb weight of about $1970 \mathrm{lb}$ and a fuel economy of approximately $35 \mathrm{mpg}$ or $1.12 \mathrm{kWh} / \mathrm{mi}$. Thus, the new vehicles, despite weight disadvantages, are expected to consume substantially less input energy per mile than gasolinefueled cars. This will result from contemplated reductions in aerodynamic drag and rolling resistance, and from substantially improved propulsion efficiency. The peak brake thermal efficiency of the gasoline engine is only expected to increase to about 0.33 from approximately 0.30 in 1978. The gasoline ICE is expected to retain its poor part load efficiency associated with throttling; thus, the average propulsion efficiency over the Federal Urban driving cycle in 1990 will be roughly 0.17.

The high energy consumption of gasoline cars is offset by a quite high overall source-to-vehicle input efficiency. With petroleum as a resource, and allowing efficiencies of $0.90,0.98$, and 0.98 for refining, transporting, and charging gasoline into cars, respectively, an overall efficiency of 0.86 results. The bottom line numbers for Table 1 are therefore 1.82 and $1.30 \mathrm{kWh} / \mathrm{mi}$ of source energy for 1978 and 1990 gasoline-fueled ICE cars, respectively. Considering the imprecision of this comparison, it is concluded that in the 19.90 model year, the four-passenger LSHV will use coal energy as effectively as a comparable gasoline-fueled car will use the dwindling petroleum energy resources. The other vehicles in the table will consume up to one-third more resource energy per mile than the gasoline-fueled car. If coal were used to produce synthetic gasoline, an approximate one-third reduction in the efficiency of conversion/refining would be expected, raising the 1990 gasoline-fueled car's source energy consumption to about $1.95 \mathrm{kWh} /$ mi. Such a vehicle would be a less effective user of coal energy than any of the options considered in this study. Its operation would consume half again. as much coal as the LSHV.

\subsection{OVERVIEW}

Market penetration and energy availability forecasts were not within the scope of this study but would be necessary to fully compare the two 
basic vehicle systems or to compare them with alternatives based on liguid hydrocarbon fuels. Regional differences could have significant effects on energy supplies, energy costs and, for EV's, performance under adverse weather conditions. Nonhomogeneity is certain for hydrogen production and distribution capability, and for excess electric energy at reasonable cost, so strong regional preferences for particular propulsion systems can be expected. HV's will, at best, be supported in the near term by an evolving local or regional fuel network. Development of facilities primarily to provide liquid hydrogen for aircraft or rail use could have a great effect on the local availability of hydrogen for cars. Residential electrolyzers can immediately solve the problem of fueling GSHV's but require substantial initial investments and assure low energy efficiency and high cost. The vehicles would however be lighter, smaller, and more amenable to range increases than EV's.

Hybrid versions of the $\mathrm{HV}$ and EV propulsion systems were outside the scope of this study. The screening of the less significant propulsion approaches by this study permits future studies to be properly focused on a narrower spectrum of issues regarding energy, materials, cost, and performance, and on the pros and cons of hybridization.

Since data in this study primarily reflect a mid-1977 cutoff date for technology inputs and outside study results, refinement of some inputs is appropriate and could affect comparative results. Data received in December 1978, for instance, include somewhat altered development goals by Argonne National Laboratory, primarily for the advanced lithium-aluminum/ ir on sulfide battery. These changes could not be incorporated into the report. The principal effect of the altered goals is a shift to the conservative values listed for the advanced battery (in Subsection 4.1) at an indefinite time. However, an extraordinary doubling of the density for this advanced battery was cited. The effect on vehicle range would be the same as a $30-\mathrm{Wh} / \mathrm{kg}$ increase in battery specific energy. Thus, new support is available for the validity of the model year $2000 \mathrm{EV}$ weight/range projections presented herein.

This report provides sufficient detail on methodology to allow the use of different input assumptions to suit personal judgments and the refinement of knowledge with time from technological developments, new forecasts for energy costs, and results of vehicle operational evaluations. 
Hydrogen does not appear in any substantial quantities in. elemental form, that is, as free hydrogen in the earth's crust or atmosphere. As a highly reactive, readily oxidized element, it appears chemically bound in stable compounds such as water and hydrocarbons. To release hydrogen from the chemical bonds of these feedstocks, energy must be applied, typically in the form of heat or electricity. Fossil sources of hydrogen vary greatly in their hydrogen-to-carbon ratios, from the desirably high values for methane (principal constituent of natural gas) and naphtha to the lower values for heavy oils (petroleum, shale oil) and coal. They can serve as energy sources by combustion with oxygen or air to accommodate the generation of hydrogen by a number of processes. When hydrocarbons are used as feedstocks, water is inevitably used as a second feedstock. The proportion of the hydrogen derived from the water is greatest where the hydrogen-tocarbon ratio is lowest. Coal, therefore, requires more water to produce a given amount of hydrogen than does methane. Carbon or coal char would obviously serve only as a fuel in a hydrogen production process with water since all hydrogen would derive from the splitting of water.

Only the reaction of hydrocarbons with water and water dissociation using electricity from nonfossil resources appear applicable to largescale hydrogen production. The present emphasis on natural gas as the major feedstock and energy material in U.S. hydrogen production (by steam reforming) is certainly expected to shift to the less desirable but relatively abundant coal resources. Up to the year 2000, any large-scale hydrogen production from water is expected to be based on electrolysis. Plants based on thermochemical processes using nuclear reactor heat sources may come into being after that date. This study included detailed consideration of current and developing hydrogen processes associated with fossil sources, nuclear fission reactors, solar energy systems (including ocean thermal energy conversion 
systems), and other nonfossil energy sources. The purposes of this summary are served by a limited discussion of several hydrogen production processes but inclusion of the efficiency values projected for the production and delivery of energy from all major sources.

The Koppers-Totzek process is illustrative of proven coal gasification technology that has been used around the world for 25 years. In this process, normally moist coal enters the plant, where roughly one quarter is diverted for boiler and dryer fuel and the remainder is reacted with oxygen and steam in a gasifier. The product gas is put through a sequence of processes including scrubbing, ash removal, compression, sulfur removal, catalytic carbion monoxide shift to carbon dioxide (which is discharged), methanation, drying, and final compression to $1000 \mathrm{psi}$. On a comparative weight basis, the quantity of moist coal entering the plant is matched by approximately the same amount of steam and water and about half as much oxygen. This produces about a tenth the amount of high pressure gas of 93 to 94 percent hydrogen purity (the remainder being mostly methane) and less than 0.5 percent sulfur (Ref. 1).

The 0.57 efficiency of the Koppers-Totzek process in converting the heating value of coal to the heating value of the product gas can be exceeded by other processes, such as the continuous steam-iron process $(0.63$ efficiency, pilot plant production phase) and the U-Gas process ( 0.66 efficiency) (Ref. 1). The efficiencies of the processes are dependent to some extent on the composition of the coal and on its moisture content and whether or not waste heat is recovered in the form of electricity. The costs of coal gasification facilities are very high, and their amortization and return on investment represent 70 to 75 percent of the cost of the hydrogen produced (Ref. 2). Figure 1 presents the price of hydrogen (in 1977 dollars per million Btu) for the Koppers-Totzek (current) and the U-Gas (advanced) processes as a function of coal cost (Refs. 3 and l, respectively). 


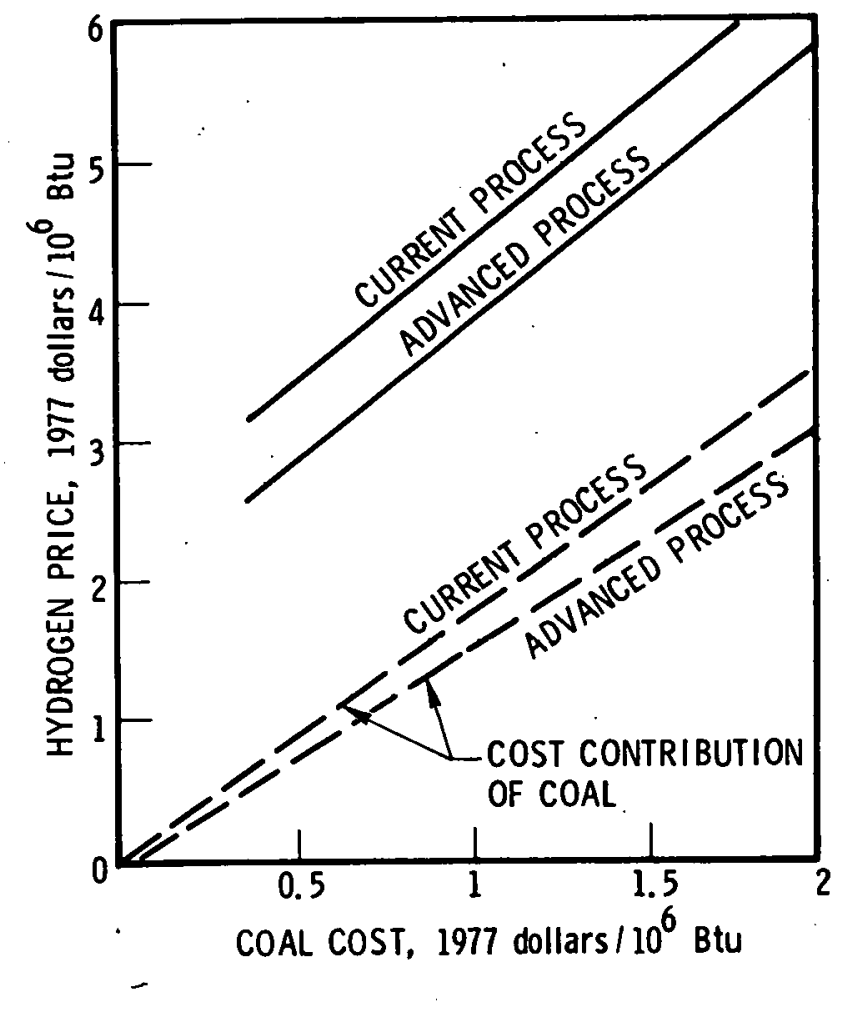

FIGURE 1. HYDROGEN PRODUCTION COST VERSUS COAL COST

The primary futurc alternative to coal gasification is electrolysis, which has seen substantial use where cheap, abundant electricity (hydro generated) is available. The passage of direct current through an electrochemical cell consisting primarily of an anode, a cathode, and an electrolyte (such as an aqueous, potassium hydroxide solution) causes hydrogen to be continuously evolved at the cathode and oxygen to be evolved at the anode. Production electrolyzers combine many such cells in either tank (unipolar) or filter-press (bipolar) configurations. The unipolar design is less expensive in construction but lowe $r$ in efficiency. The filter-press design operates at higher current densities and temperatures and is more amenable to generation of moderate pressure hydrogen, which is highly advantageous considering the relative ease of pumping water to that pressure level. 
Existing technology Stuart tank and Lurgi filter-press electrolyzers have current densities of 200 to $300 \mathrm{~A} / \mathrm{ft}^{2}$, operating efficiencies of 75 to 80 percent, and total equipment cost (not including installation) of about $\$ 300 / \mathrm{kW}$ of output hydrogen energy. A 1 - to 3-year technology effort to develop bipolar units should raise efficiency about 5 percent, while increasing the current density range to 300 to $400 \mathrm{~A} / \mathrm{ft}^{2}$ and lowering equipment cost to about $\$ 210 / \mathrm{kW}$. Technology advances by 1985 in solid polymer electrolyte systems should permit efficiencies in the 85- to 90-percent range with current densities of 1000 to $1500 \mathrm{~A} / \mathrm{ft}^{2}$, reducing equipment cost to $\$ 45$ to $\$ 85 / \mathrm{kW}$. The lower cost results from elimination of power conditioning equipment and replacement of the equipment with an acyclic generator connected directly to the electrolyzer cell stack (Refs. 4,5). Figure 2 presents the price of electrolytic hydrogen (in 1977 dollars per million Btu) for current (Lurgi) and advanced (GE solid polymer electrolyte) bipolar electrolyzers (Ref. 4). Although equipment costs for advanced systems are markedly reduced, the cost of electricity is the dominant consideration. The cost of electrolytic hydrogen will remain substantially above that of hydrogen from coal unless electricity can be made available at about $1 \notin / \mathrm{kWh}$. The costs of nuclear facilities and fuels are not expected to produce such a balance. Facility operation and amortization costs will almost certainly prevent other nonfossil energy forms (hydro, solar, geothermal, aerodynamic, and those from solid waste) from achieving such a power cost.

Another process in hydrogen production that may be very important in transportation applications is liquefaction. This process permits hydrogen to be transported and used in a low-pressure, acceptably dense form, which influences vehicle design, performance, cost, safety, and ease of fueling. A large liquefaction plant (on the order of 250 tons/day capacity) is required to permit a reasonable efficiency to be achieved (36 to 37 percent) in liquefying very pure hydrogen, which ideally requires $6050 \mathrm{Btu} / 1 \mathrm{~b}$, compared to hydrogen's lower heating value of $51,600 \mathrm{Btu} / \mathrm{lb}$. The electric energy consumption alone, at $3 \notin / \mathrm{kWh}$, accounts for almost $\$ 3 / \mathrm{million}$ Btu of the product liquid hydrogen. 


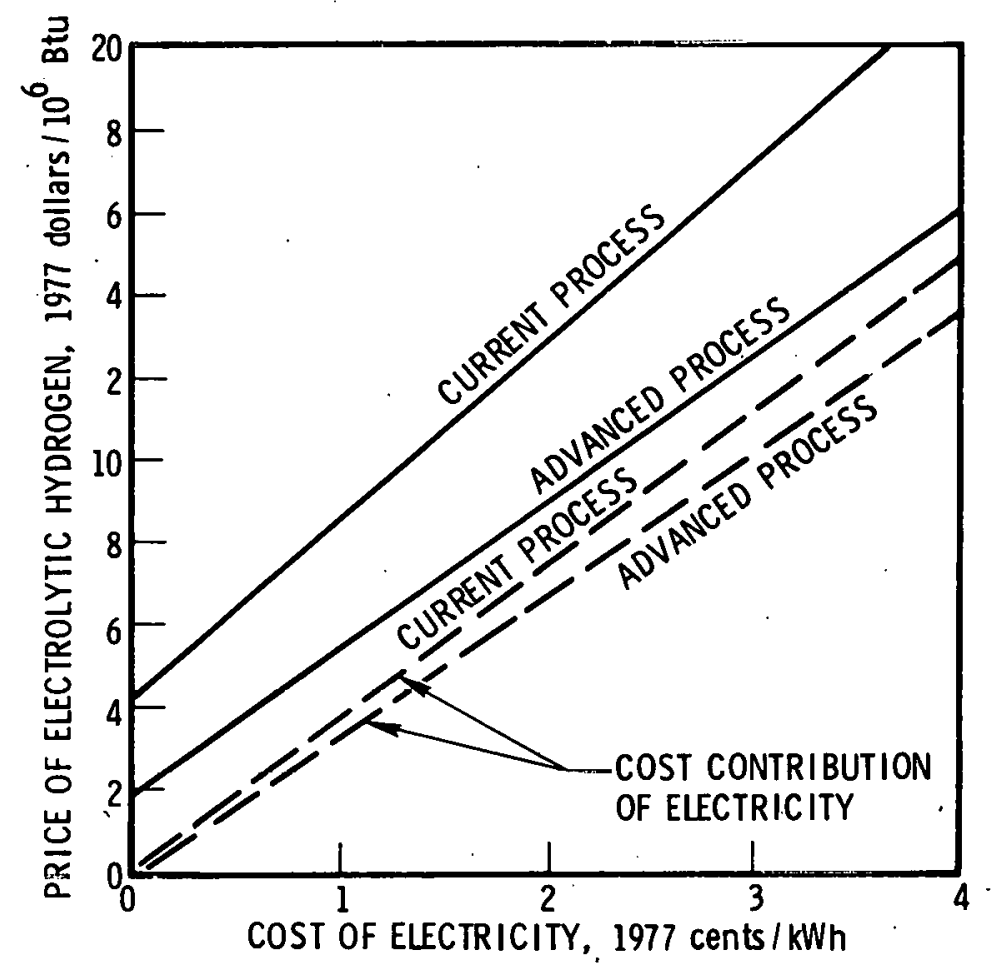

FIGURE 2. HYDROGEN PRODUCTION COST VERSUS ELECTRICITY COST

2.2

\section{DELIVERY}

Delivery from the hydrogen source to the user vehicle can involve modes of long distance transmission, in-transit storage, distribution, and retail station storage and dispensing operations. All viable transportation and storage modes were considered in the study, and cost estimates for capital equipment and operating expenses were provided where available. There is, of course, no extant infrastructure for the distribution of automotive hydrogen. Although technical problems are tractable, capital investment"requirements are very large, especially if significant storage capacity is needed. The low energy content per unit volume of gaseous hydrogen (about one-third to one-fourth that for natural gas, depending on pressure level) will require large pipe diameters, relatively high line pressures, and much higher pumping station power levels and fuel consumption than for natural gas transmission. Compatibility with the existing natural gas pipeline network requires further evaluation because of these factors, in addition to numerous possibilities for hydrogen embrittlement damage, mismatch of energy sources and pipe sizes, : and inadequacy of distribution coverage for automotive use. Liquid hydrogen transmission is costly by pipeline but quite reasonable by rail, truck, and 
marine shipment; the rail and truck modes have been adequately demonstrated in the industrial gas sector in commercial service and in support of space programs.

At the dispensing station, the greatest uncertainty exists because of the possible need for highly trained personnel (depending upon success in automated refueling) and requirements for safety precautions, special equipment and procedures, and adequate space.

3.

HYDROGEN VEHICLE ASSESSMENT

3.1

ENERGY STORAGE

The results of this study indicate that the currently feasible and demonstrated means of storing hydrogen fuel in a car are as a very lowtemperature $\left(-423^{\circ} \mathrm{F}\right)$, low-pressure, low-density liquid or as a low-pressure, low-density adsorbed gas in a powdered metal. Limited attention was given in this study to hydrogen bound in compounds requiring chemical change prior to use, such as methanol, ammonia, methylcyclohexane, sodium borohydride, and other solids suitable for thermochemical reactions. All such systems have problems of feasibility, complexity, safety, or cost.

Of the two practical storage methods, the liquid hydrogen approach is lighter and less complex, but requires excellent insulation for the storage tank and its attachments to limit vaporization while the vehicle is standing. Potential problems demanding careful design attention include freezing of valves, liquefaction of atmospheric constituents, embrittlement of materials, pump failure, and safe venting of any boil-off gas. Engine coolant or electric heating must be applied to the tank system to satisfy the engine's gaseous hydrogen demand if a liquid hydrogen pump is not used.

Metal hydrides, some of which are listed in Table 2 (Refs.6, $7,8,9)$, can absorb, at best, a modest percentage of hydrogen. They liberate heat when charged with hydrogen (necessitating cooling provisions) and require a substantial heat source in the vehicle to satisfy the dissociation temperature and heat energy needed to deliver hydrogen to the engine. Irontitanium can be made to hold up to $1.6 \mathrm{wt} \%$ of hydrogen and will liberate it at a modest temperature (about $0^{\circ} \mathrm{C}$ ), using heat normally wasted by the engine coolant and exhaust. The low-temperature heat needed by iron-titanium 
TABLE 2. PROPERTIES OF CERTAIN METAL HYDRIDES (Refs. $6,7,8,9$ )

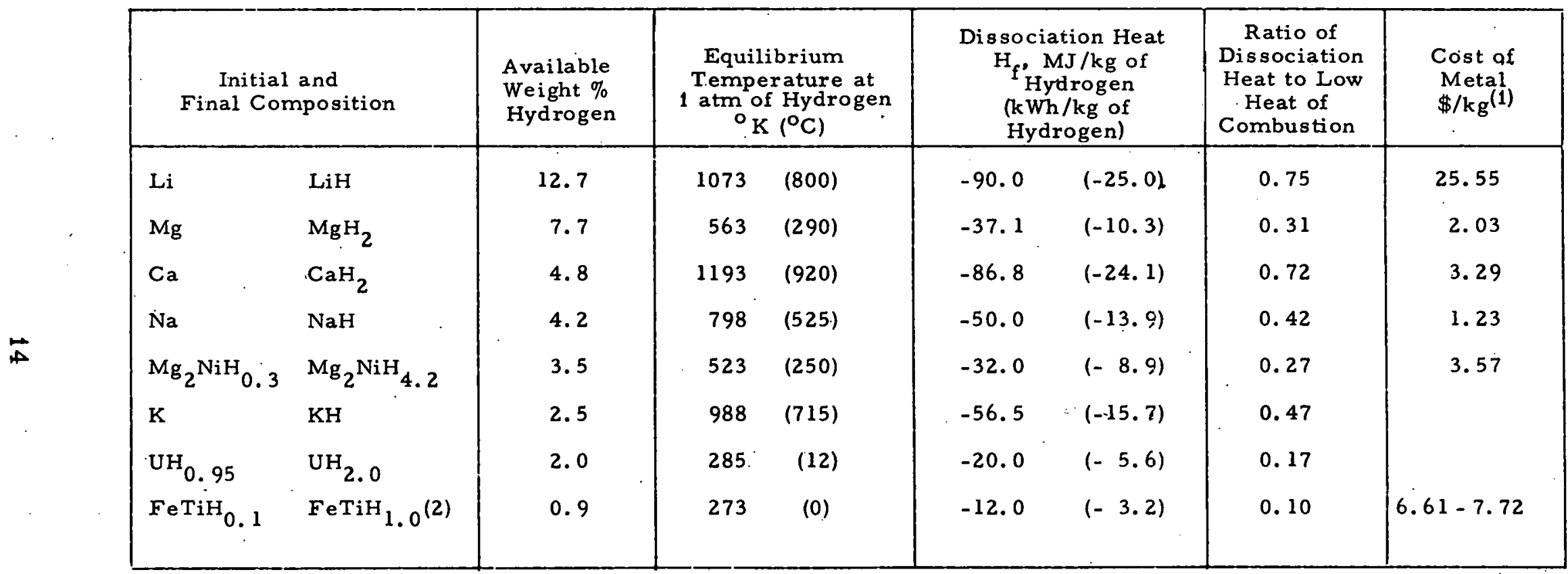

(1) The costs presented are ingredient cost: (May 1977) except for iron-titanium hydride, which shows an alloy cost (December 1976).

${ }^{(2)}$ With more complete hydriding at elevated pressure, iron-titanium can deliver 1.5 percent hydrogen by weight. 
hydride while delivering hydrogen accommodates design of a simple air conditioning system featuring a blower to circulate compartment air through heat exchange coils in the hydride tank. Among the metals frequently mentioned as a replacement for iron-titanium is magnesium. As shown in Table 2, it holds $7.7 \mathrm{wt} \%$ of hydrogen, but the hydride must operate above $290^{\circ} \mathrm{C}$. In addition, the energy required to liberate the hydrogen from the metal at 1 atm is equivalent to 31 percent of the hydrogen's heating value. This is more energy than can be recovered from the engine's exhaust.

Alloys of magnesium with nickel and other constituents are being sought to yield 5 percent hydrogen at $200^{\circ} \mathrm{C}$ or less (Ref. 10). It is expected that about 15 . percent of the liberated hydrogen would have to be burned to satisfy dissociation heat requirements. A dual-hydride system, featuring separate tanks containing high-temperature and low-temperature hydrides, would diminish the fraction of hydrogen that would have to be burned. It would do this by allowing the low-temperature hydride to be dissociated by engine coolant and/or partially cooled exhaust gas from the high-temperature hydride tank heat exchanger. The resultant system would be more complex than a single high-temperature hydride system and would have physical, performance, and cost properties between those of the two hydrides. Figures 3 and 4 indicate the relative complexity of near-term, low-temperature hydrides, like iron-titanium hydride, and that of more advanced high-temperature types, like magnesium alloys (Ref. 11). The latter have other performance drawbacks associated with high-temperature gas being fed to the engine (low specific output or efficiency) and with low bulk density of the powdered alloy and hydride (resulting in greater tank and vehicle weights than would be expected considering the hydrogen weight fraction).

Ideal engine performance for a naturally aspirated, spark ignition, hydrogen/air ICE is presented in Figure 5 (Ref. 12). Thermal efficiency is seen to increase with compression ratio and with a reduction in equivalence ratio $\phi$, the actual hydrogen-to-air ratio compared with the stoichiometric value. Up to a point, inefficient throttling of air at low loads can be avoided by merely reducing hydrogen flow, thus increasing efficiency. Experimentation on many engines has revealed problems of hydrogen flashback, preignition, 


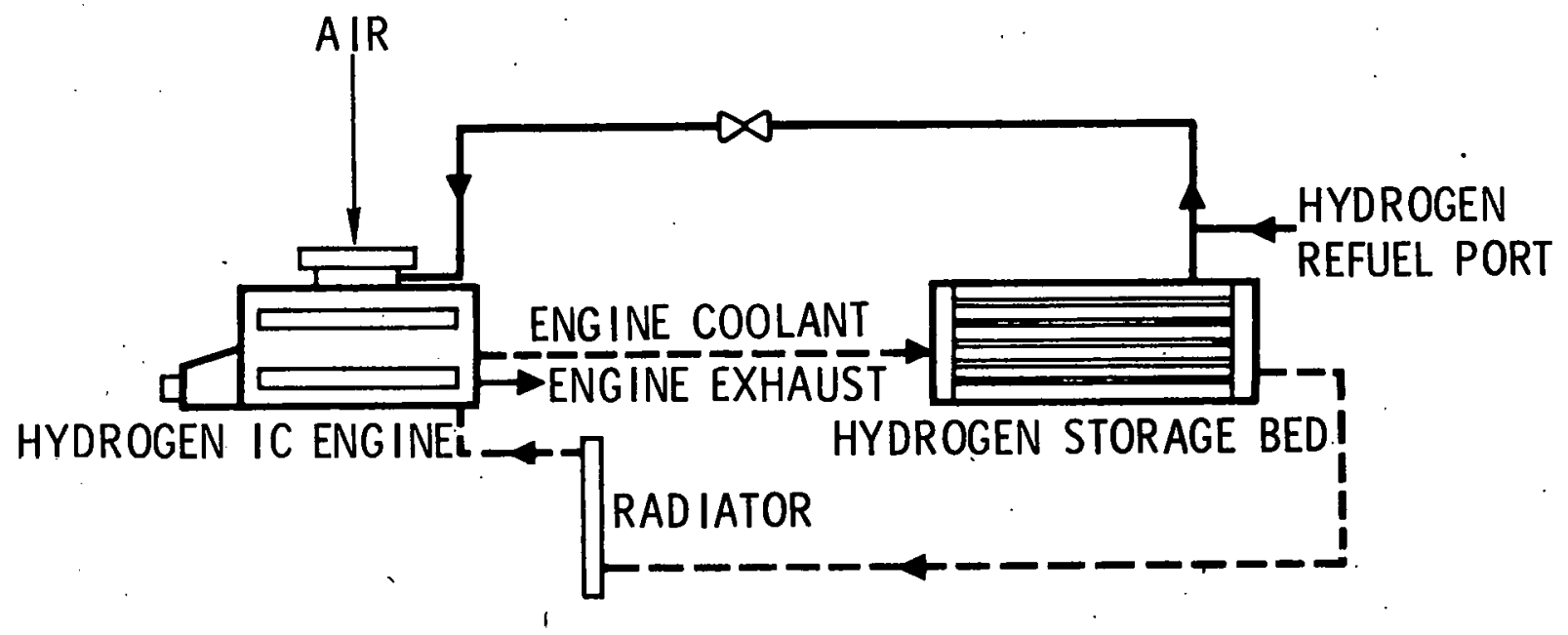

FIGURE 3. AUTOMOTIVE HYDROGEN STORAGE SYSTEM - LOW TEMPERATURE HYDRIDE (Ref. 11)

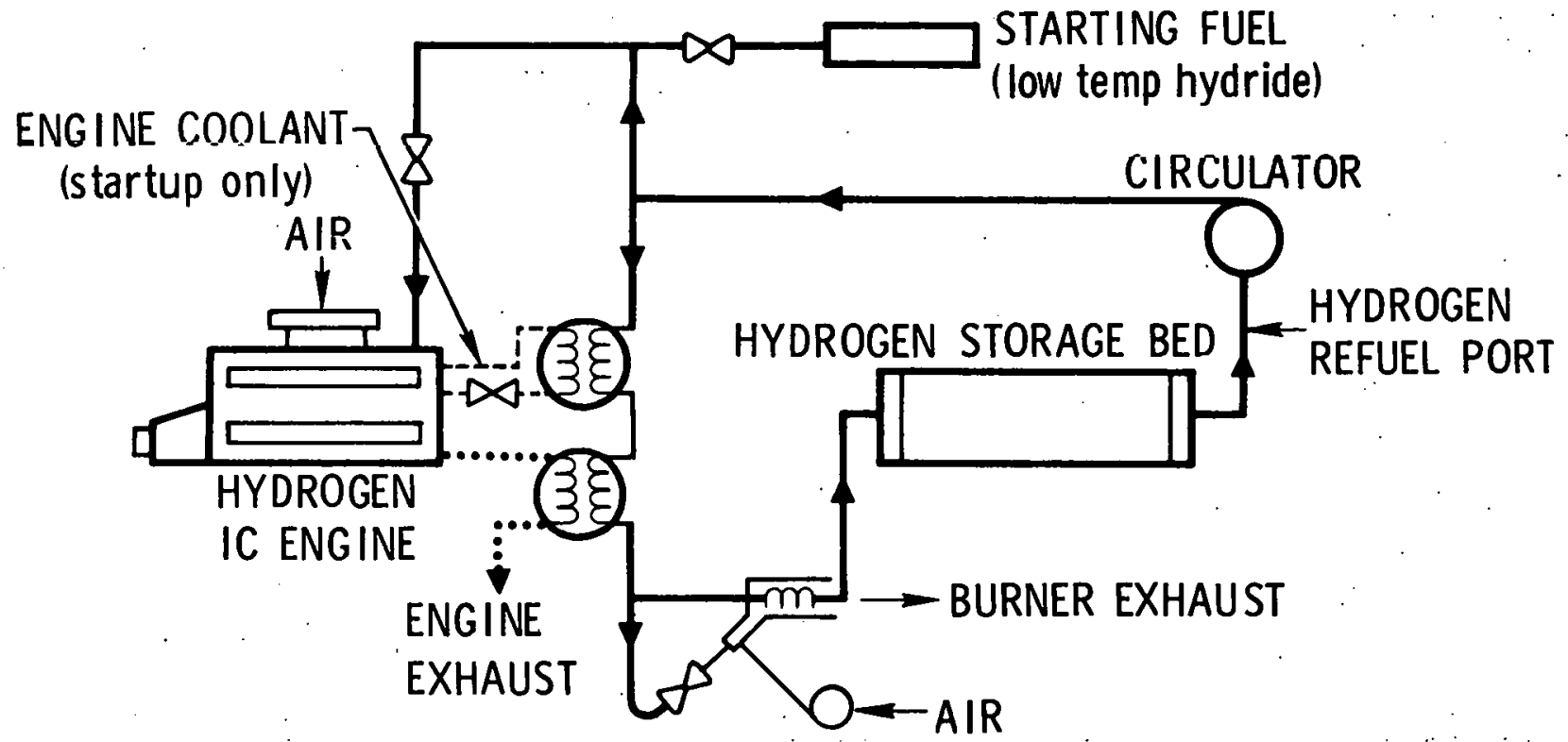

FIGURE 4. AUTOMOTIVE HYDROGEN STORAGE SYSTEM - CONVECTIVE HIGH TEMPERATURE HYDRIDE STORAGE UNIT (Ref. 11) 


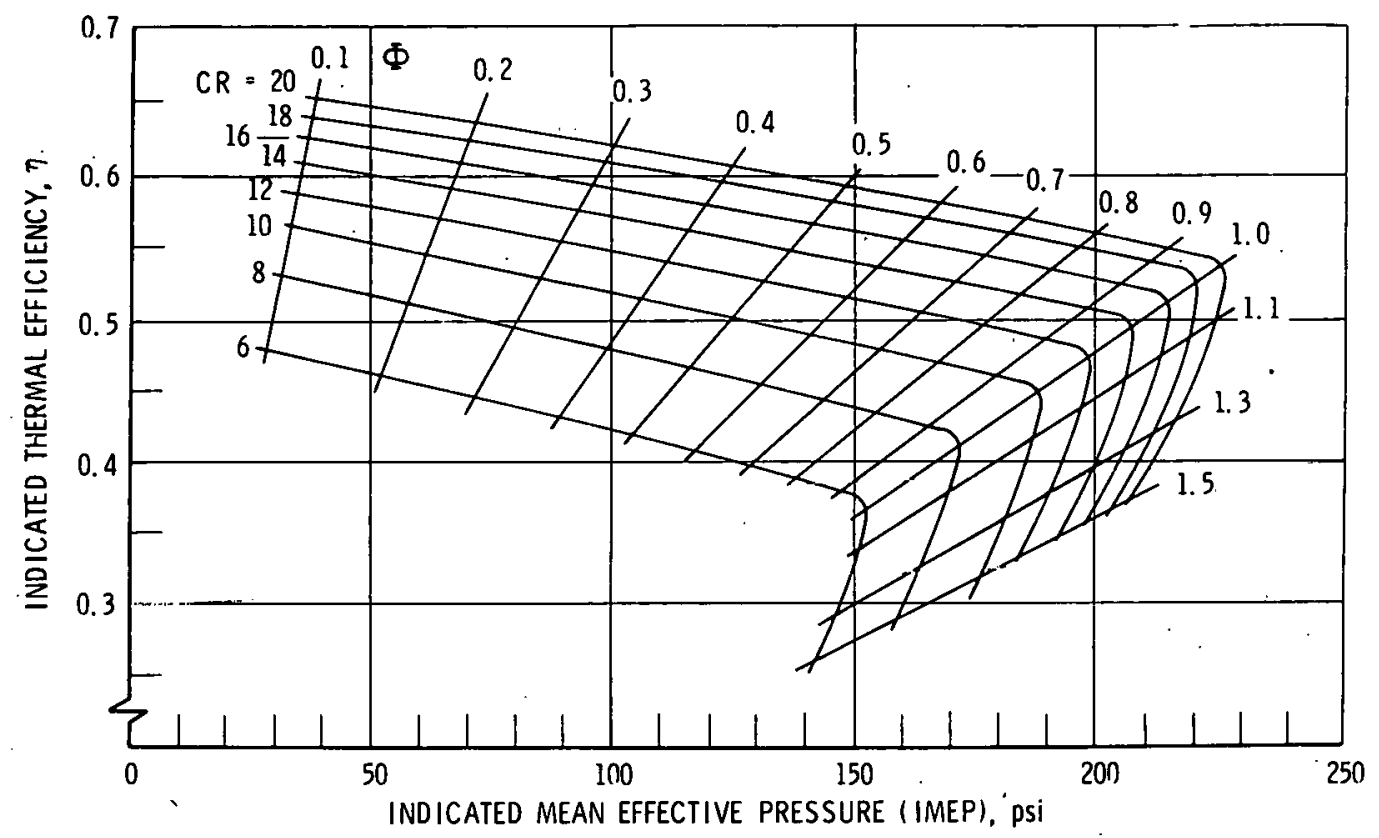

FIGURE 5. IDEAL PERFORMANCE MAP FOR NATURALLY ASPIRATED, SPARK IGNITION, HYDROGEN/AIR ENGINES (FUEL/AIR OTTO CYCLE) (Ref. 12)

low engine power, and undesirably high $\mathrm{NO}_{\mathrm{x}}$ emissions. Data on one engine are presented in Figure 6 (Ref. 13). Current engine problems can be controlled using various design techniques, ignition and valve timing variation, wate $r$ injection, and exhaust gas recirculation. More significant improvements in performance are expected for direct cylinder injection of gaseous hydrogen.

The principal problems in automotive applications of hydrogen are summarized in Table 3.

3.3

SAEETY HAZARDS

Hydrogen is a unique fuel with unique problems. The concensus appears to be that it presents a greater overall hazard than most other candidate fuels. In one comparison with eight other fuels, only a few advantages were shown for hydrogen: no health hazard, ready dissipation (if unconfined), and difficult autoignition (Ref. 14). Hydrogen was judged to present the greatest hazard in the areas of leakage, volatility, confined dissipation, and deflagration. Ignition energy and flammability properties were also of great concern. In a hydride tank, hydrogen would normally have a pressure of only a few atmospheres. Upon rupture of the tank, hydrogen evolution 


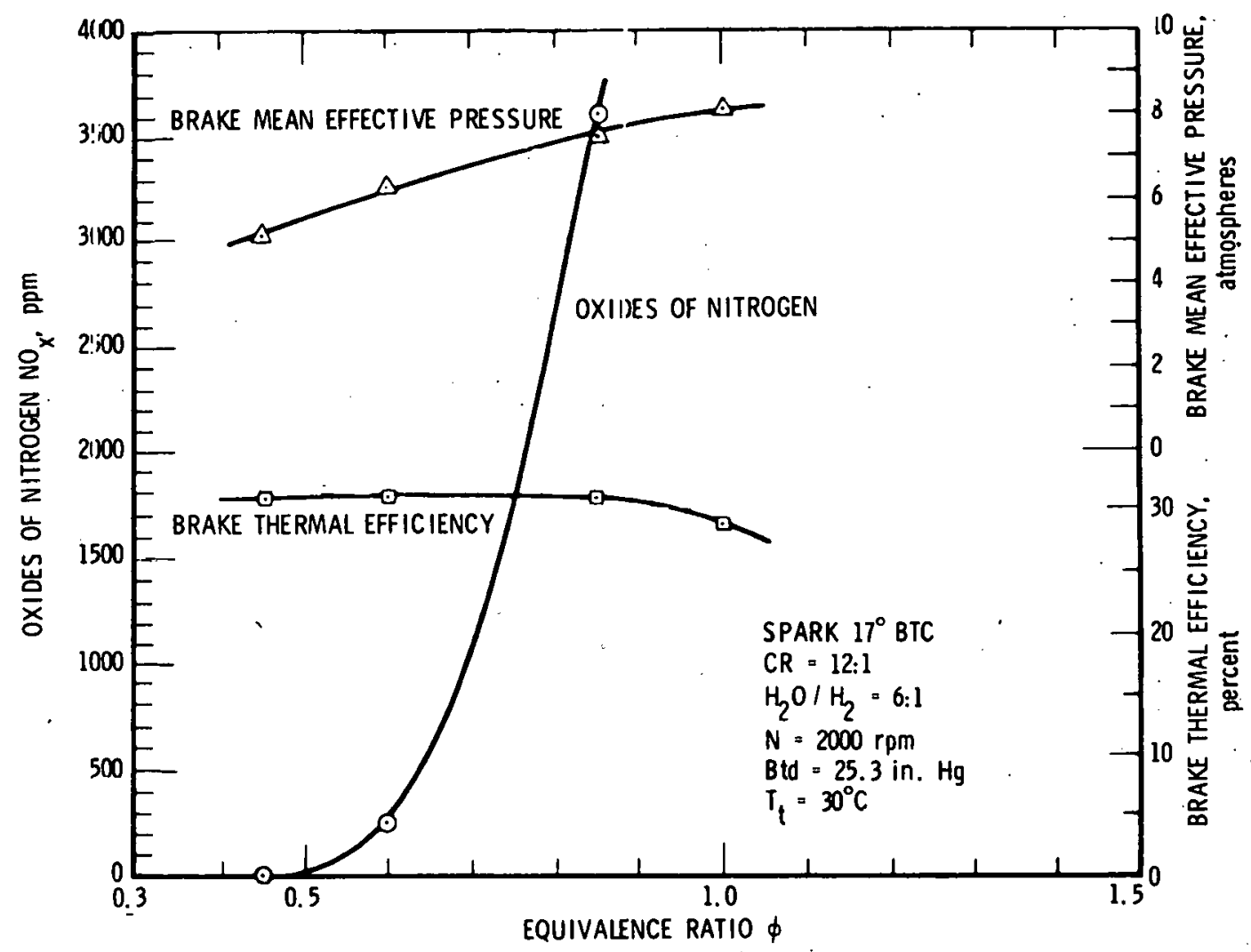

FIGURE 6. OXDES OF NITROGEN, BRAKE MEAN EFFECTIVE PRESSURE, AND THERMAL EFFICIENCY VERSUS EQUIVA LENCE RATIO (Ref. 13)

should cease with loss of the heat source (Ref. 15). However, pyrophoricity of magnesium alloy powders is a concern. Before putting liquid hydrogen in the hands of the general automotive public and maintenance personnel, a great deal of safety experimentation and education will be necessary.

4 .

\section{ELECTRIC VEHIC LE ASSESSMENT}

4.1 ENERGY STORAGE

There is a good deal of effort worldwide to develop the technology of high performance batteries for vehicular application. To achieve high energy and power per unit weight, along with long cycle lives at deep depths of discharge, many battery types are being developed that are unlike the starting, lighting, and ignition (SLI) automotive battery. Complexity is 
TABLE 3. PRINCIPAL PROBLEMS IN APPLICATION OF HYDROGEN TO SPARK IGNITION ENGINE-POWERED CAR

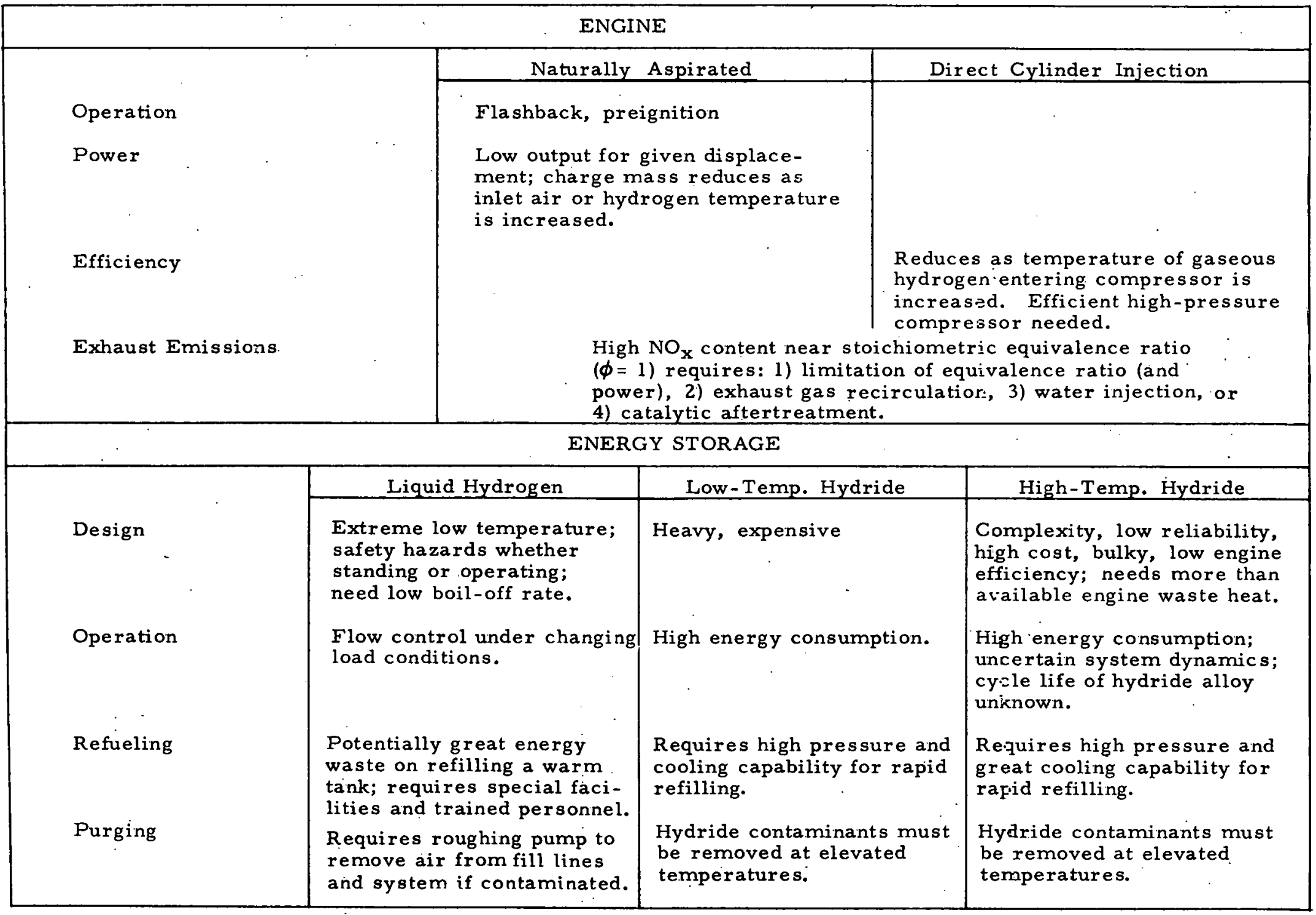


being increased in some cases, with the addition of electrolyte pumps (and possibly other pumps) and the need for cooling as illustrated in Figures 7 . and 8 (Refs. 16, 17). Several battery types employ molten materials requiring effective thermal insulation, structural integrity, and cooling provisions. One major type is represented in Figure 8 (Ref. 17). An interesting capability of the zinc/chlorine hydrate battery shown in Figure 7 is the potential for providing simple air conditioning of an operating automobile by circulating compartment air around the hydrate store to provide the heat needed to melt the hydrate ice.

Table 4 presents the principal characteristics of the representative batteries used in the vehicle performance and cost analyses (Refs. 18 , 19, 20, 21). The data provided for 1985 model year car applications are 1981 development goals for multiple contracts funded through Argonne National Laboratory (ANL) for each battery type. Additions to battery development funding were mandated in Public Law 94-413, The Electric and Hybrid Vehicle Research, Development, and Demonstration Act of 1976. These additions give high assurance of success in one or more of the battery systems: lead/acid, nickel/iron, and nickel/zinc. The 1990 model year characteristics of the lithium-aluminum/iron sulfide, high-temperature battery represent ANL 1985 development goals under multiple contracts. Data for the 1990 model year zinc/chlorine hydrate battery are values the battery developer expects to meet or exceed by around 1982. Although other batteries could be selected to represent usage in the year 2000, speculation on their characteristics was felt to weaken the vehicle comparisons. Instead, improvements of up to 20 percent in key characteristics were considered for the batteries assumed for model year 1990. The values tabulated in this report for the year $2000 \mathrm{EV}$ assume use of a lithium-aluminum/iron sulfide battery 20 percent improved over 1990 model year assumptions in all parameters except density (higher values in last column of Table 4 except for cost range). An additional analysis was made assuming only 10 percent improvements confined to specific energy and power values (lower values in last column of Table 4 except for cost range). 


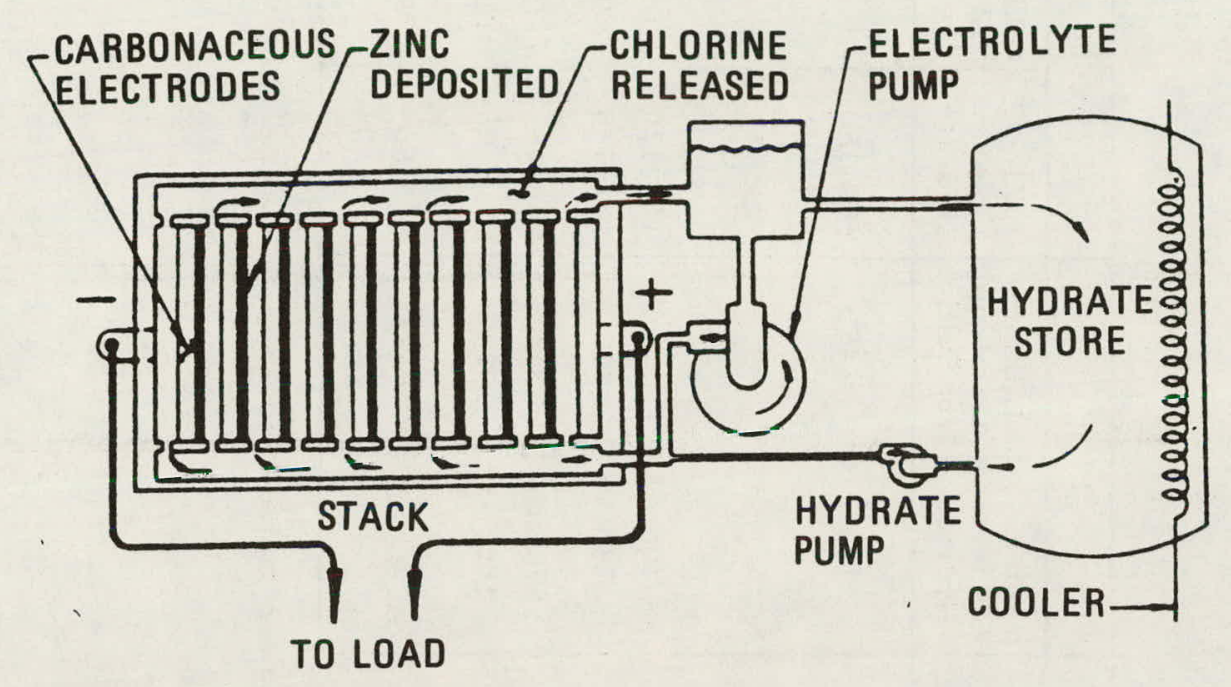

FIGURE 7. ZINC/CHLORINE HYDRATE BATTERY SCHEMATIC (Ref. 16)

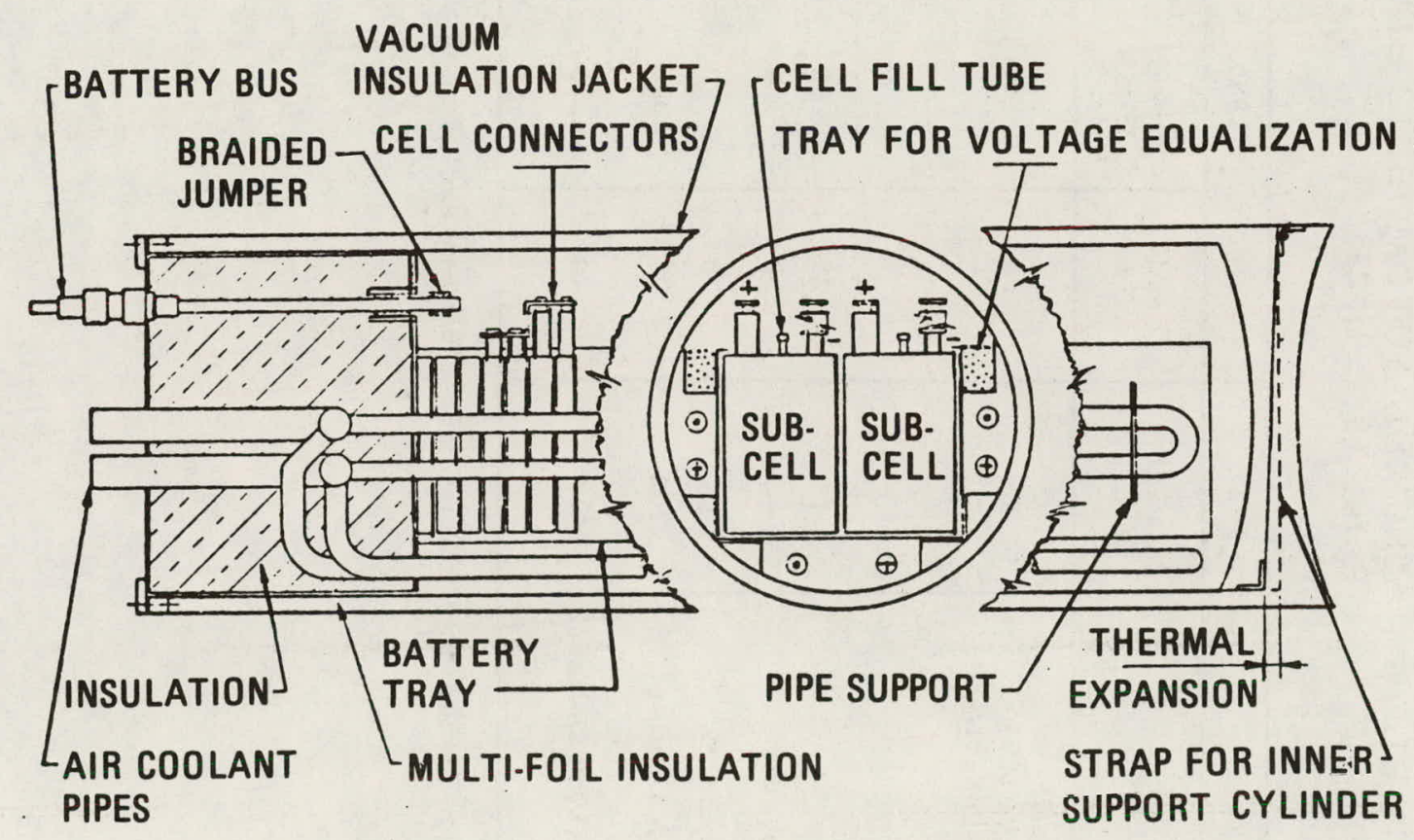

FIGURE 8. SECTIONAL VIEW OF 30-kWh LITHIUM-ALUMINUM/IRON SULFIDE VEHICLE BATTERY (Ref. 17) 
TABLE 4. ASSUMED AUTOMOBILE BATTERY CHARACTERISTICS (Refs. 18, 19, 21)

\begin{tabular}{|c|c|c|c|c|c|c|c|c|}
\hline Model Year & 1977 & & 1985 & & & 90 & 20 & 00 \\
\hline Battery Type & $\begin{array}{l}\text { Lead/ } \\
\text { Acid }\end{array}$ & $\begin{array}{l}\text { Lead/ } \\
\text { Acid }\end{array}$ & $\begin{array}{l}\text { Nickel/ } \\
\text { Iron }\end{array}$ & $\begin{array}{l}\text { Nickel/ } \\
\text { Zinc }\end{array}$ & $\begin{array}{l}\text { Zinc/ } \\
\text { Chlorine } \\
\text { Hydrate }\end{array}$ & $\begin{array}{l}\text { Lithium- } \\
\text { Aluminum/ } \\
\text { Iron Sulfide }\end{array}$ & $\begin{array}{l}\text { Zinc/ } \\
\text { Chlorine } \\
\text { Hydrate }\end{array}$ & $\begin{array}{l}\text { Lithium } \\
\text { Aluminum/ } \\
\text { Iron Sulfide }\end{array}$ \\
\hline $\begin{array}{l}\text { Specific Energy (100\% } \\
\text { Depth of Discharge), } \\
\text { Wh/kg } \\
\text { Specific Power, } \\
\text { W/kg }\end{array}$ & 30 & 50 & 60 & 90 & 150 & 145 & $165-180$ & $160-175$ \\
\hline Sustained & 15 & 25 & 50 & 50 & 100 & & $110-120$ & \\
\hline Peak ( $50 \%$ charge) & 50 & 150 & 200 & 200 & 150 & 200 & $165-180$ & $220-240$ \\
\hline Ene=gy Efficiency, $\%(1)$ & 65 & 70 & 70 & 70 & 65 (est) & $75[21]$ & $65-78$ & $75-90$ \\
\hline $\begin{array}{l}\text { Cycie Life }(80 \% \text { Depth of } \\
\text { Discharge) }\end{array}$ & 700 & 1000 & 2000 & 700 & 1000 & 1000 & $1000-1200$ & $1000-1200$ \\
\hline Cost, $\$ / \mathrm{kWh}$ (1980 Dollars) & 50 & 40 & $50-60$ & $50-60$ & 50 & $50[21]$ & $40-60$ & $40-60$ \\
\hline
\end{tabular}

${ }^{(1)}$ Gverall charge-discharge efficiency of the battery excluding charger and power controller losses. 
The specific power vs specific energy curves for several battery systems are presented in Figure 9 (Ref. 22). Clearly, high power demands on a battery result in rapid battery discharge and in a sharp reduction of total delivered energy.

\subsection{DRIVETRAIN CHARACTERISTICS}

The range and speed capabilities of an EV depend on the performance and efficiency of the battery in addition to the efficiencies of the drivetrain elements, including the electric motor, the motor controller, the transmission, and the drive axle assembly (consisting of a reduction gear, differential, bearings, and axles). Figure 10 shows the efficiency curves of a typical direct current (dc) drive motor at 25, 50, and 100 percent load (Ref. 23). To keep motor size small, maximum cruise speed may be set near 100 percent load, and high peak loads of short duration may be satisfied by the transient overload capability of the motor. The overall drivetrain efficiency, exclusive of the drive axle assembly, is shown in Figure 11 for typical full load and cruise conditions (Ref. 24). A simple two- or three-speed gearbox of approximately 95 percent efficiency is assumed for the transmission.

The minimum design features and performance criteria for all vehicles in this study are listed in Table 5, along with specific EV drivetrain efficiencies. All vehicles are required to be capable of performing the same standard driving cycle and to have propulsion systems capable of a lifetime mileage of $100,000 \mathrm{mi}$. Replacement of worn-out batteries may be necessary to realize these capabilities. The HV's are assumed to have the same pas senger capacity, cruise speed, and aerodynamic and rolling resistance characteristics as those noted in Table 5 for EV's; however, they have substantially lower powertrain efficiencies (from engine or controller input to drive wheels). Depending upon the hydrogen engine and storage system chosen, the average driving cycle powertrain efficiency varies from 24 to 31 percent. The 64- to 66-percent drivetrain efficiency range for the EV's quoted in Table 5 does not include the battery efficiency of 65 to 90 percent. Hydrogen-engine rated power levels are higher than those for $\mathrm{EV}^{\prime} \mathrm{s}$, because transient overloads are less effective in meeting peak power demands. Turbocharging of hydrogen engines has not been considered. 


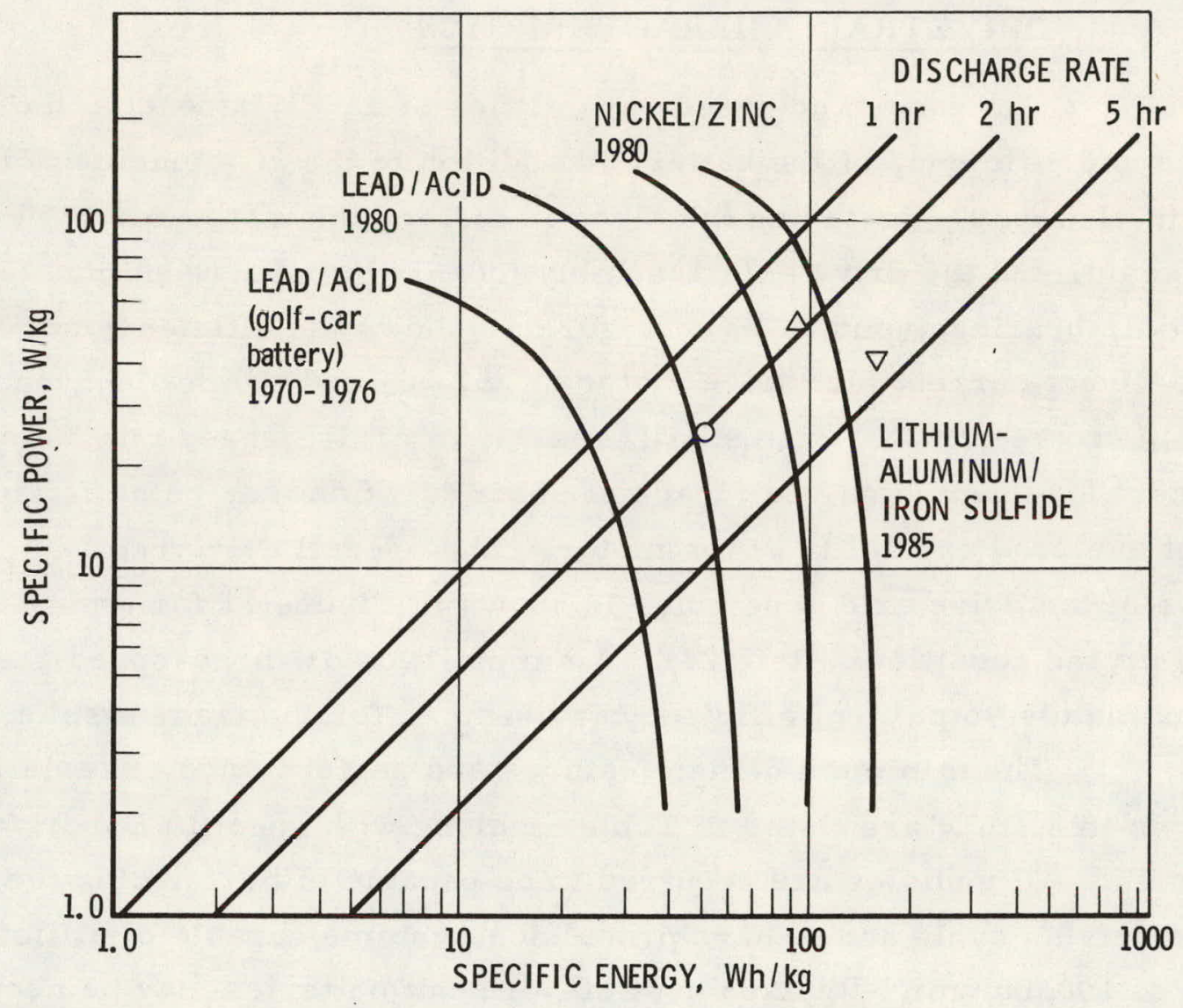

ARGONNE NATIONAL LABORATORY DEVELOPMENT GOALS

○ LEAD / ACID (1981)

$\triangle$ NICKEL/ZINC (1981)

$\nabla$ LITHIUM-ALUMINUM/ IRON SULFIDE (1985)

FIGURE 9. POWER AND ENERGY DENSITIES OF REPRESENTATIVE BATTERIES (Refs. 18, 19, 21, 22) 


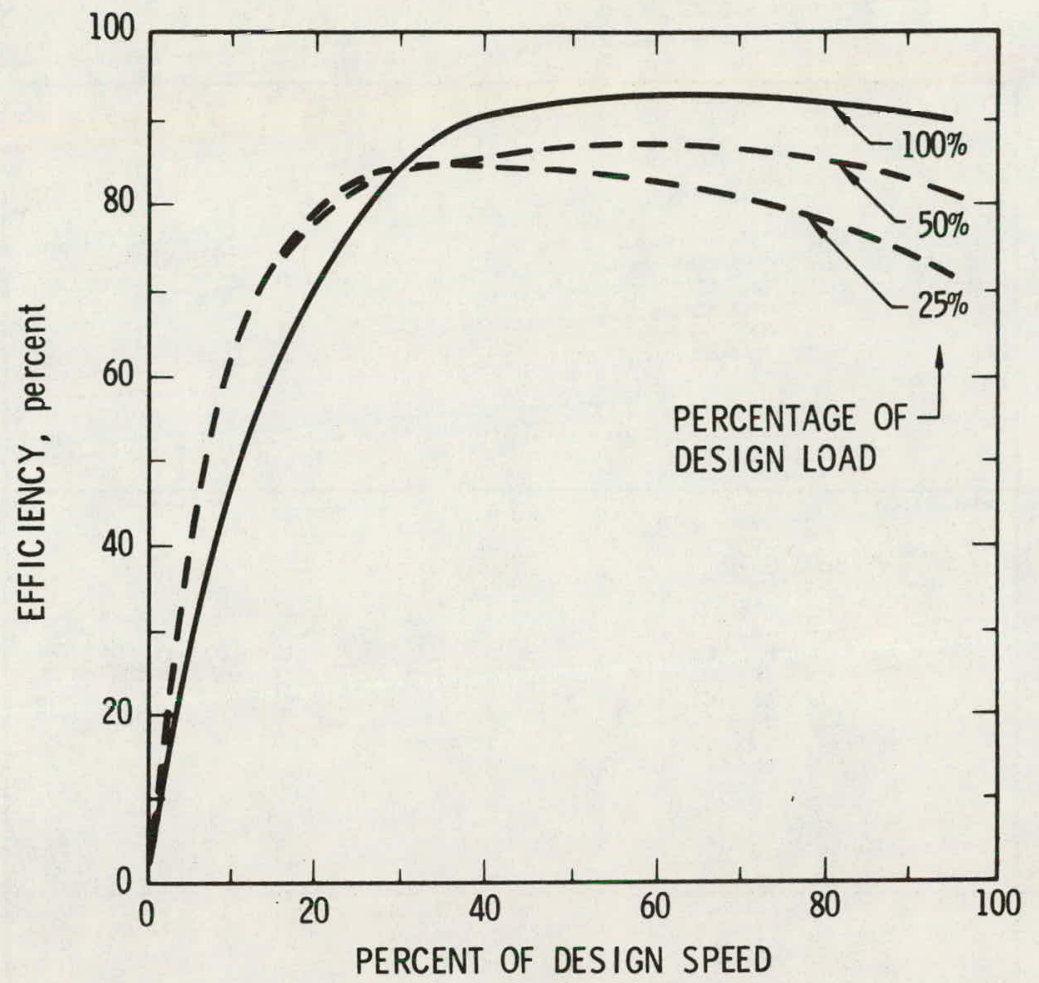

FIGURE 10. TYPICAL DIRECT CURRENT TRACTION MOTOR EFFICIENCIES AS A FUNCTION OF DESIGN LOAD AND SPEED (Ref. 23)

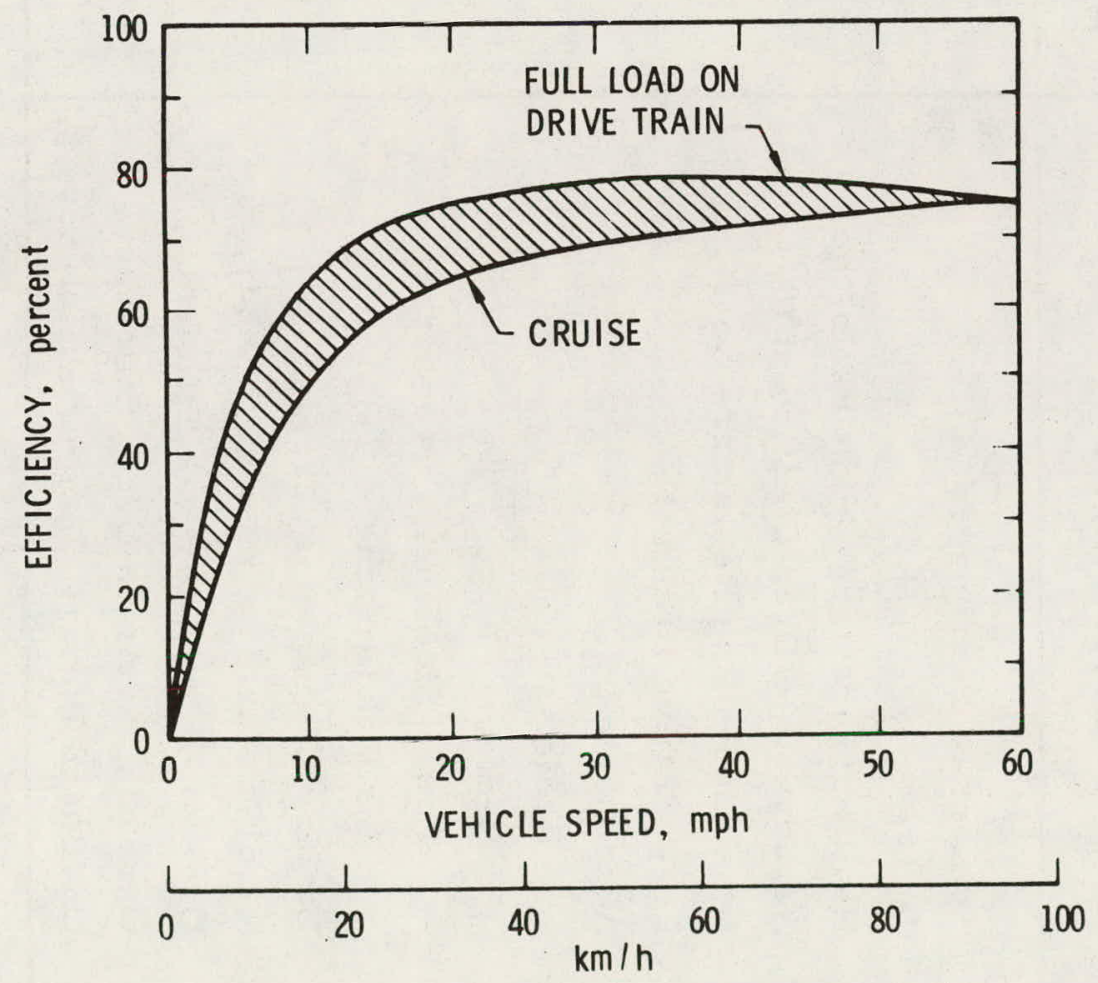

FIGURE 11. ESTIMATED ELECTRIC VEHICLE DRIVETRAIN EFFICIENCY AT CRUISE AND FULL LOAD (Ref. 24) 
TABLE 5. ELECTRIC VEHICLE DESIGN AND PERFORMANCE CRITERIA

\begin{tabular}{|c|c|c|c|}
\hline \multirow{2}{*}{ Characteristics } & \multicolumn{3}{|c|}{ Model Year $(1),(2)$} \\
\hline & 1985 & 1990 & 2000 \\
\hline Number of Passengers & 4 & 4 & 4 \\
\hline Cruise Speed, $\mathrm{mph}$ & 60 & 60 & 60 \\
\hline Peak Horsepower/Weight Ratio, hp/lb & 0.014 & 0.014 & 0.014 \\
\hline Aerodynamic Drag Coefficient $\left(0^{\circ}\right.$ Yaw $)$ & $0.35-0.40$ & $0.30-0.35$ & $0.25-0.30$ \\
\hline Nominal Rolling Resistance Coefficient & 0.012 & 0.010 & 0.008 \\
\hline Regenerative Braking & $\checkmark$ & $\sqrt{ }$ & $\sqrt{ }$ \\
\hline Accessories: & & & \\
\hline Radio & $\sqrt{ }$ & $\sqrt{ }$ & $\sqrt{ }$ \\
\hline Heater & $\sqrt{ }$ & $\sqrt{ }$ & $\sqrt{ }$ \\
\hline Power Steering, Power Brakes & $\sqrt{ }$ & $\sqrt{ }$ & $\sqrt{ }$ \\
\hline Air Conditioning & $\mathbf{x}$ & $x$ & $\sqrt{ }$ \\
\hline Battery Characteristics & Table 4 & Table 4 & Table 4 \\
\hline Motor/Controller Peak Efficiency, \% & 85 & 86 & 88 \\
\hline Overall Drivetrain Peak Efficiency, $\%$ & 75 & 76 & 78 \\
\hline Overall Drivetrain Cycle Efficiency, \% & 64 & 65 & 66 \\
\hline On-Board Battery Charger Efficiency, $\%$ & 90 & 90 & 90 \\
\hline
\end{tabular}

(1) Vehicle range selection will be based on tradeoff of usefulness, weight, and cost.

(2) $\sqrt{ }=$ Practical Capability; $\mathrm{x}=$ Impractical in most applications. 
The principal hazards of EV's stem from the characteristics of the battery: its voltage, operating temperature (presence of molten materials), toxicity and corrosiveness of its electrolyte, and the integrity of its structure and plumbing. The choice of a nominal $50-\mathrm{V}$ system should alleviate electric shocks, the most typical hazard to the owner and maintenance personnel. The other hazards of a baltery electric propulsion system will demand great attention since the bulk of the battery will be located within the physical limits defined by the car's wheels and will not be overhung beyond them. In the event of a crash, the location and proper restraint of the dense battery package will be critical to occupant safety. Safe operation of EV's among other vehicles while climbing hills or merging with freeway traffic can significantly increase required powertrain power capability and battery size beyond the demands of a simple driving cycle. Addition of an energy storage device with a high transient output, like a flywheel, could be an optimal solution.

5 . DEFINITION OF VEHICLE CHARACTERISTICS

5.1 DRIVING CYCLE PARAMETRIC ANALYSIS

A simple driving cycle, reasonably representative of the intended vehicle usage, was selected as a common base for comparing all vehicles: the Society of Automotive Engineers J227a, Schedule D driving cycle used for evaluation of EV capability (Ref. 25). Many current EV's cannot meet its modest acceleration demand, which is 0 to $45 \pm 1 \mathrm{mph}$ in $28 \pm 2 \mathrm{sec}$, as shown in Figure 12. Modern cars of widespread appeal must at least meet this demand and should be capable of prolonged cruising at 55 to $60 \mathrm{mph}$. Parametric analysis of the requirements of this driving cycle led to preparation of seven working charts, two of which are presented in Figures 13 and 14 of this report. Figure 13 presents propulsion energy requirements as functions of vehicle weight and coefficients of aerodynamic drag and rolling resistance. Figure 14 presents the $60-\mathrm{mph}$ cruise and peak cycle horsepower values as functions of the same parameters. Other plots prepared using the same parameters include cycle distance, braking energy, and horsepower vs speed. These are presented in Section 5, Volume III of this report. 
$\stackrel{\sim}{\infty}$

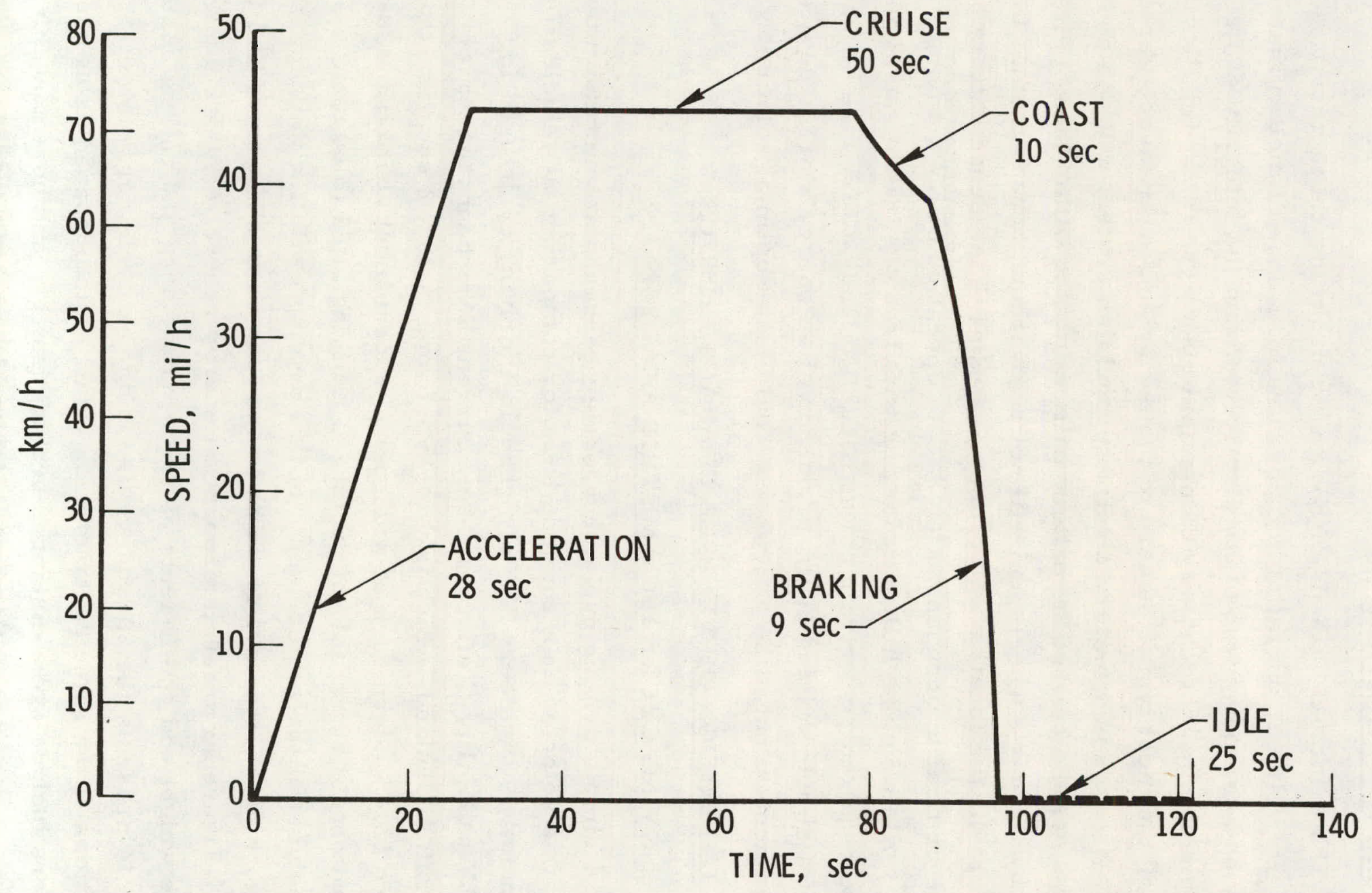

FIGURE 12. SOCIETY OF AUTOMOTIVE ENGINEERS J227a, SCHEDULE D DRIVING CYCLE (Ref. 25) 


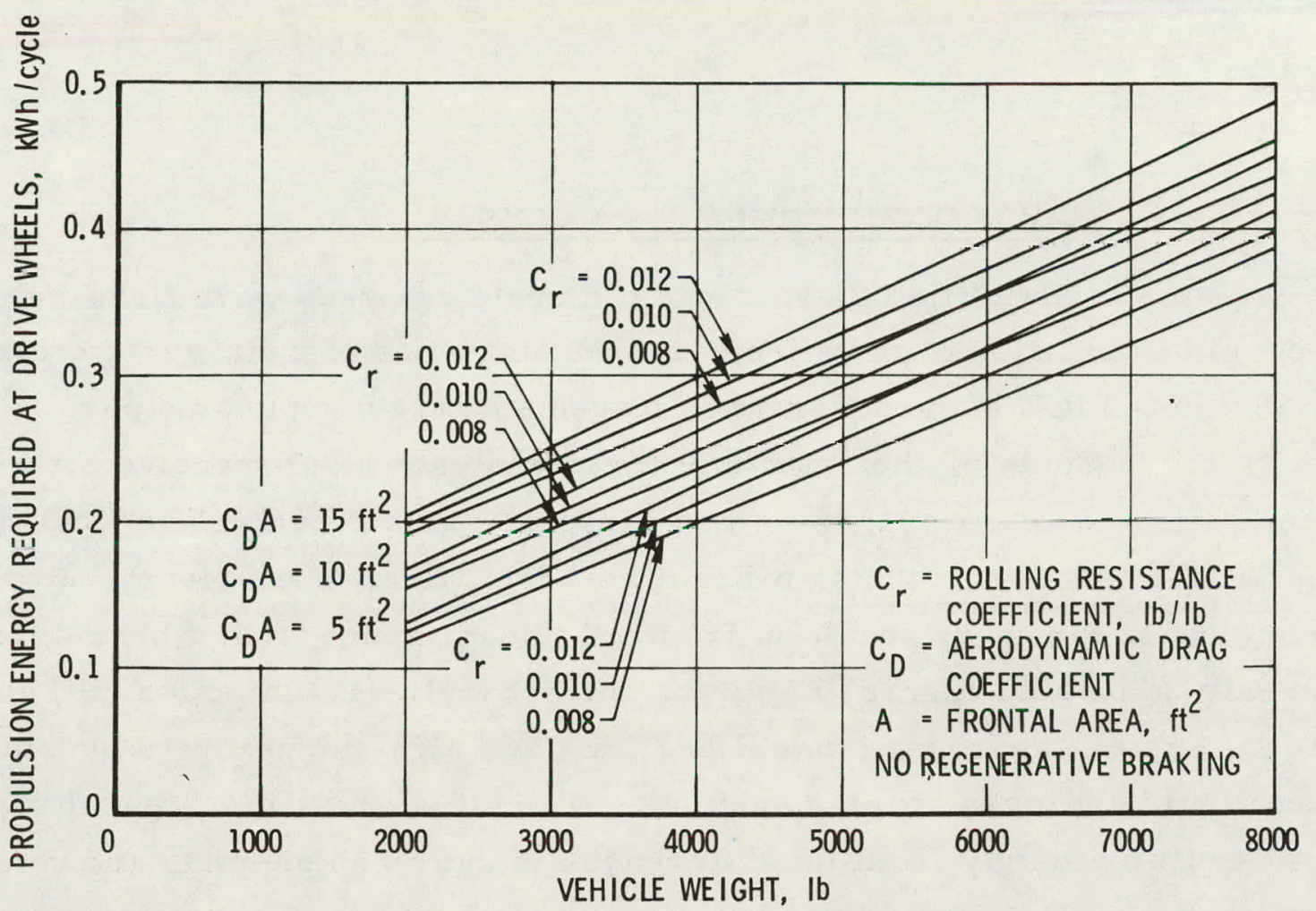

FIGURE 13. PROPULSION ENERGY REQUIREMENTS OF SOCIETY OF AUTOMOTIVE ENGINEERS J227a, SCHEDULE D DRIVING CYCLE

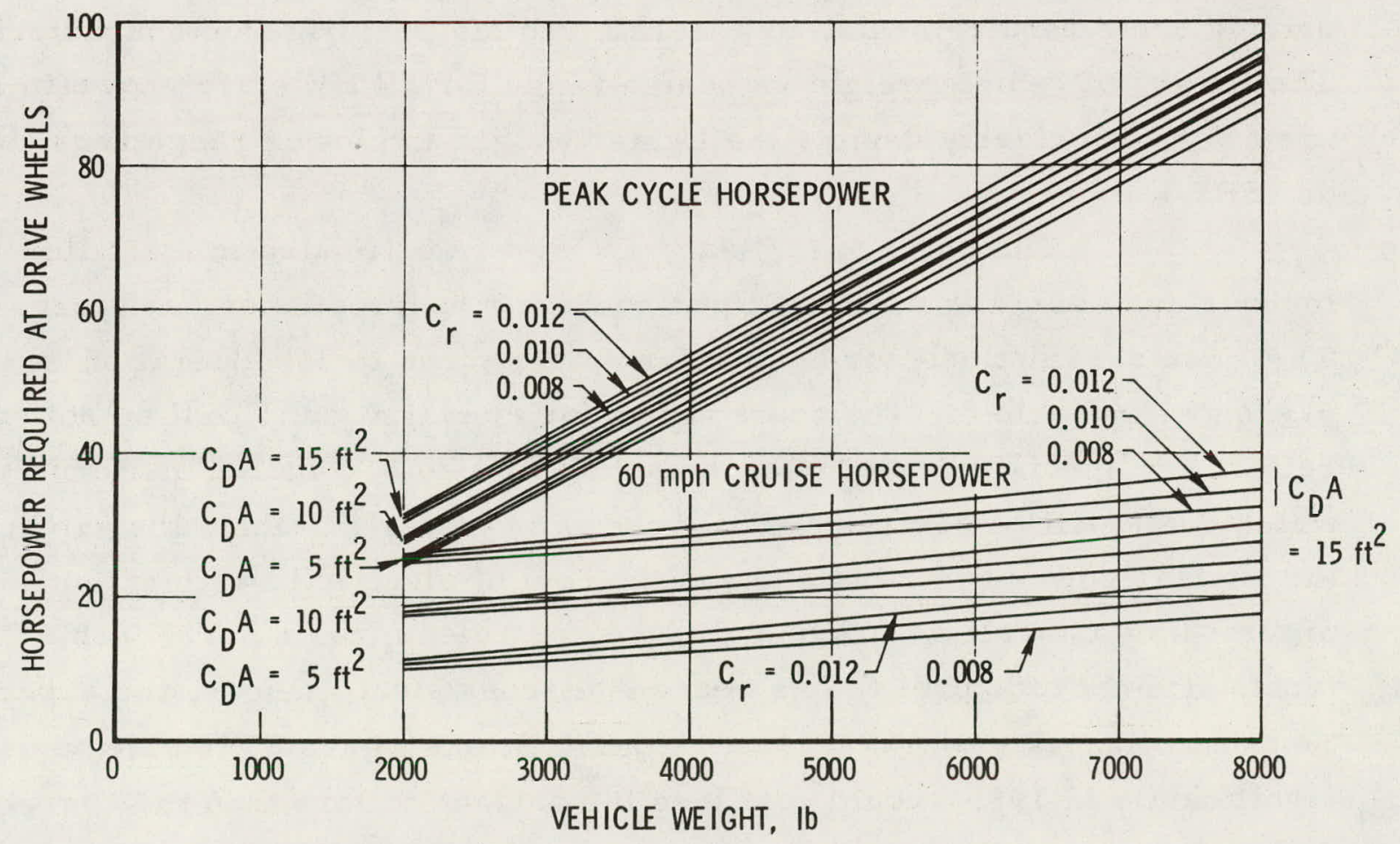

FIGURE 14. HORSEPOWER REQUIREMENTS OF SOCIETY OF AUTOMOTIVE ENGINEERS J227a, SCHEDULE D DRIVING CYCLE 
Simplified thermodynamic cycle analyses were first undertaken to permit estimation of the effects of different types of hydrogen-powered, spark-ignited ICE's and different hydrogen sources upon engine performance and size. In Table 6 , the results of these analyses are presented for an equivalence ratio of unity $(\phi=1)$ and a compression ratio of $14: 1$. The final five lines in the table show the significant relative values of efficiency, displacement, and horsepower resulting from the advancement from a near-term, naturally aspirated engine to a future, direct (cylinder) injection (DI) engine. The latter uses hydrogen from either low- and high-temperature hydride or from liquid hydrogen storage systems. The differences in engine characteristics result primarily from the differences in hydrogen pumping and compression powers. The approximate effects on combined engine and transmission weight are shown in Table 7 .

Vehicle weight estimation equations, suitably modified from those of gasoline-powered vehicles (Ref. 26), were employed, along with driving cycle requirements, to generate vehicle performance characteristics. The curves of vehicle weight vs design range for all HV's are shown in Figure 15, which clearly depicts the lighter weight and lower range sensitivity of LSHV's.

The costs of $\mathrm{HV}^{\prime} \mathrm{s}$ and EV's we re estimated in a similar manner and using the same cost per pound for nonpropulsion hardware. The cost assumptions for energy forms pertinent to $\mathrm{HV}$ operation are presented in Table 8. The costs shown for electricity and coal do not reflect any special knowledge of the authors on such complex matters as which coals will be environmentally and economically usable, the extent of the nuclear power contribution, and the cost of electricity vs location with diminishing natural gas usage and higher petroleum costs. The Table 8 inputs attempt to express, in a reasonably consistent manner, the expectation that off-peak power--at least in the locations where EV's may be used significantly in 1985--could cost less in constant dollars than the current national average cost. However, such power cost will likely continue to 
TABLE 6. RESULTS OF HYDROGEN ENGINE CYCLE ANALYSES ${ }^{(1)}$

\begin{tabular}{|c|c|c|c|c|}
\hline \multirow[b]{3}{*}{$\begin{array}{l}\text { Inlet Hydrogen Pressure and } \\
\text { Temperature, psia } /{ }^{\circ} \mathrm{F}\end{array}$} & \multirow{3}{*}{\begin{tabular}{|c|}
$\begin{array}{c}\text { Naturally } \\
\text { A spirated ICE }\end{array}$ \\
$14 / 80$ \\
\end{tabular}} & \multicolumn{3}{|c|}{ Direct Cylinder Injection ICE } \\
\hline & & \multicolumn{2}{|c|}{ Compressed Hydrogen } & \multirow{2}{*}{$\begin{array}{c}\text { Purrped Hydrogen } \\
14 f^{\prime} \geq-423\end{array}$} \\
\hline & & $14 / 80$ & $14 / 200$ & \\
\hline Temperature of Inlet $\mathrm{Mix},{ }^{\circ} \mathrm{F}$ & 108 & - & - & - \\
\hline $\begin{array}{l}\text { Ideal Cylinder Charge Density, } \\
\mathrm{lb} / \mathrm{ft}^{3}\end{array}$ & $\begin{array}{l}0.0482 \\
\text { (mixture) }\end{array}$ & $\begin{array}{c}0.0652 \\
\text { (air) } \\
0.0671 \\
\text { (corr. for } \mathrm{H}_{2} \text { ) }\end{array}$ & $\begin{array}{c}0.0652 \\
(\text { air) } \\
0.0671 \\
\text { (corr. for } \mathrm{H}_{2} \text { ) }\end{array}$ & $\begin{array}{c}0.0652 \\
(3 i r) \\
0.0671 \\
\text { (corr. for } \mathrm{H}_{2} \text { ) }\end{array}$ \\
\hline $\begin{array}{l}\mathrm{H}_{2} \text { Injection Pressure and } \\
\text { Temperature, psia/ }{ }^{\circ} \mathrm{F}\end{array}$ & : & $1000 / 697$ & $1000 / 853$ & $1000 / 80$ \\
\hline $\begin{array}{l}\text { Compression Work, Btu/lb } \\
\text { Air } \\
\text { Hydrogen } \\
\text { Mixture or Total }\end{array}$ & $\begin{array}{c}- \\
- \\
444\end{array}$ & $\begin{array}{r}339 \\
4682 \\
461\end{array}$ & $\begin{array}{r}339 \\
5219 \\
476\end{array}$ & $\begin{array}{l}339 \\
100 \\
332\end{array}$ \\
\hline $\begin{array}{l}\text { Air Pressure and Temperature } \\
\text { Before Mixing, psia/ } / \mathrm{F}\end{array}$ & - & $534 / 1288$ & $534 / 1288$ & $534 ; 1288$ \\
\hline $\begin{array}{l}\text { Pressure and Temperature } \\
\text { After Compression and Mixing, } \\
\text { psia } /{ }^{\circ} \text { F }\end{array}$ & $529 / 1233$ & $741 / 1249$ & $766 / 1306$ & $615 / 958$ \\
\hline $\begin{array}{l}\text { Expansion Work After Constant } \\
\text { Volume Combustion, Btu/lb }\end{array}$ & 898 & 904 & 907 & 879 \\
\hline Net Work, Btu/lb & 454 & 443 & 431 & 547 \\
\hline Thermal Efficiency & 0.312 & 0.305 & 0.280 & $0.37 i$ \\
\hline Relative Thermal Efficiency & 1.000 & 0.976 & 0.897 & 1.205 \\
\hline Relative Displ. /Charge Mass & 1,000 & 0.718 & 0.718 & 0.718 \\
\hline Relative Engine Mech. Effic. & 1.000 & l. 062 & 1.062 & 1.057 \\
\hline Relative hp/Displacement & 1.000 & 1.444 & 1.327 & 1.773 \\
\hline $\begin{array}{l}\text { Relative Tutal Displacement } \\
\text { Including Compressor or Pump }\end{array}$ & 1.000 & 1.001 & 1.158 & 0.6204 \\
\hline
\end{tabular}

(1) Compression ratio $=14: 1$.

Inlet air pressure and temperature $=14 \mathrm{psia}$ and $120^{\circ} \mathrm{F}$

Fuel/air ratio $=0.029: 1 ; \phi=1.0$

Compression and expansion efficiencies $=0.75$

Two-stage hydrogen compressor with intercooler for $200^{\circ} \mathrm{F}$ inlet to second stage. 
TABLE 7. WEIGHT OF ENGINE AND TRANSMISSION

\begin{tabular}{|c|c|c|c|c|c|}
\hline Engine Typc & $\begin{array}{l}A_{3} \\
\text { (lb) }\end{array}$ & $\begin{array}{c}\mathrm{B}_{3} \\
(\mathrm{lb} / \mathrm{cid})\end{array}$ & $\begin{array}{c}\mathrm{K} \\
(\mathrm{cid} / \mathrm{hp})\end{array}$ & $\begin{array}{c}\mathrm{B}_{3} \mathrm{~K} \\
(\mathrm{lb} / \mathrm{hp})\end{array}$ & $\begin{array}{l}W_{3} \text { for } 100 h p^{(1)} \\
(1 b)\end{array}$ \\
\hline Gasoline Engine $[26]^{(2)}$ & 310 & 1.92 & 1.30 & 2.50 & 560 \\
\hline $\begin{array}{c}\text { Naturally Aspirated Hydrogen Engine } \\
\text { Hydrogen Temperature }=80^{\circ} \mathrm{F}\end{array}$ & 310 & 1.92 & 1.34 & 2.57 & 567. \\
\hline $\begin{array}{l}\text { Direct Injection Hydrogen Engine } \\
\text { Hydrogen Temperature }=80^{\circ} \mathrm{F} \\
\text { Cryogenic Supply } \\
\text { Metal Hydride Supply }\end{array}$ & $\begin{array}{l}340 \\
370\end{array}$ & $\begin{array}{l}2.00 \\
2.30\end{array}$ & $\begin{array}{l}0.75 \\
0.92\end{array}$ & $\begin{array}{l}1.50 \\
2.12\end{array}$ & $\begin{array}{l}490 \\
582\end{array}$ \\
\hline $\begin{array}{l}\text { Hydrogen Temperature }=200^{\circ} \mathrm{F} \\
\text { Metal Hydride Supply }\end{array}$ & 370 & 2.40 & 1.00 & 2.40 & 610 \\
\hline \multicolumn{6}{|c|}{ 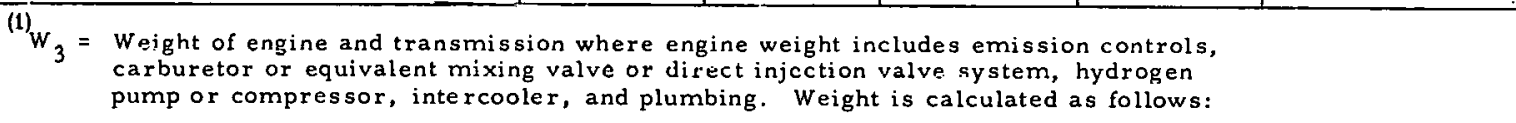 } \\
\hline $\begin{array}{l}\quad W_{3}=A_{3}+B_{3} \times \text { cid }=A_{3}+B_{3} \times K \times \\
(2)[]=\text { Reference number. }\end{array}$ & & engine di & cement in & inches. & \\
\hline
\end{tabular}

rise faster than the general inflation rate primarily because of fossil fuel depletion and increasingly stringent environmental controls. Similar reasoning applies for the cost of coal in areas where its gasification to hydrogen could be used to support a growing transportation demand. Gaseous hydrogen costs are obtained from the parametric production cost relationships shown in Figures 1 and 2, from gas pipeline transmission costs of $6 \not / 10^{6} \mathrm{Btu}-100 \mathrm{mi}$, and from distribution costs of 20 percent. The delivered costs of liquid hydrogen are obtained from results shown in Section 2, Volume 2 of this report.

The costs of hydrogen, operating expenses, and depreciation for all HV's considered are presented in Table 9, both with and without capital recovery from hydride salvage at the end of $100,000 \mathrm{mi}$. Data are presented at design ranges of 85 and $200 \mathrm{mi}$ that clearly show the total cost per mile advantage enjoyed by LSHV's, especially at long ranges. 


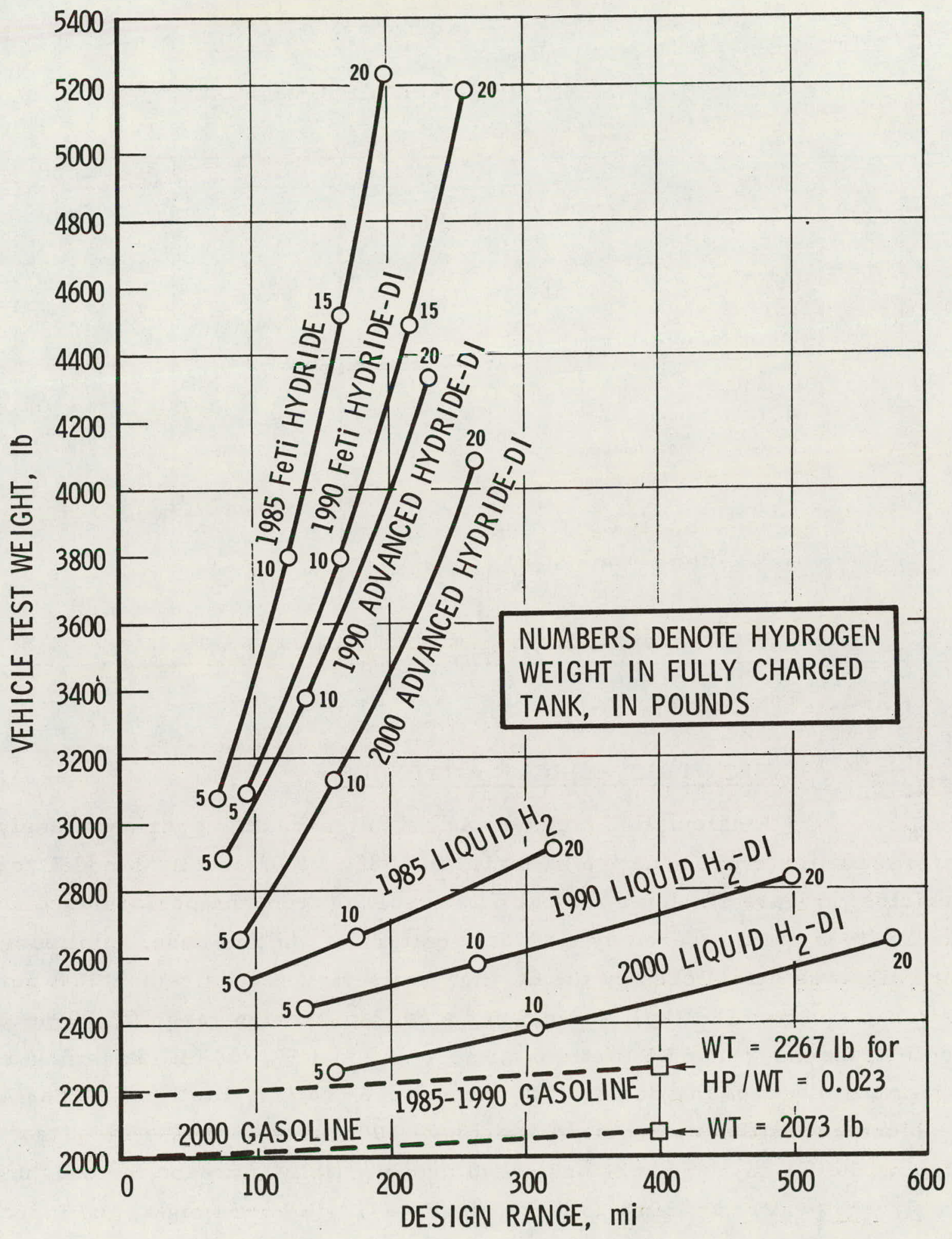

FIGURE 15. WEIGHT. OF HYDROGEN-POWERED FOURPASSENGER CARS 


\section{TABLE 8. ENERGY COST ASSUMPTIONS}

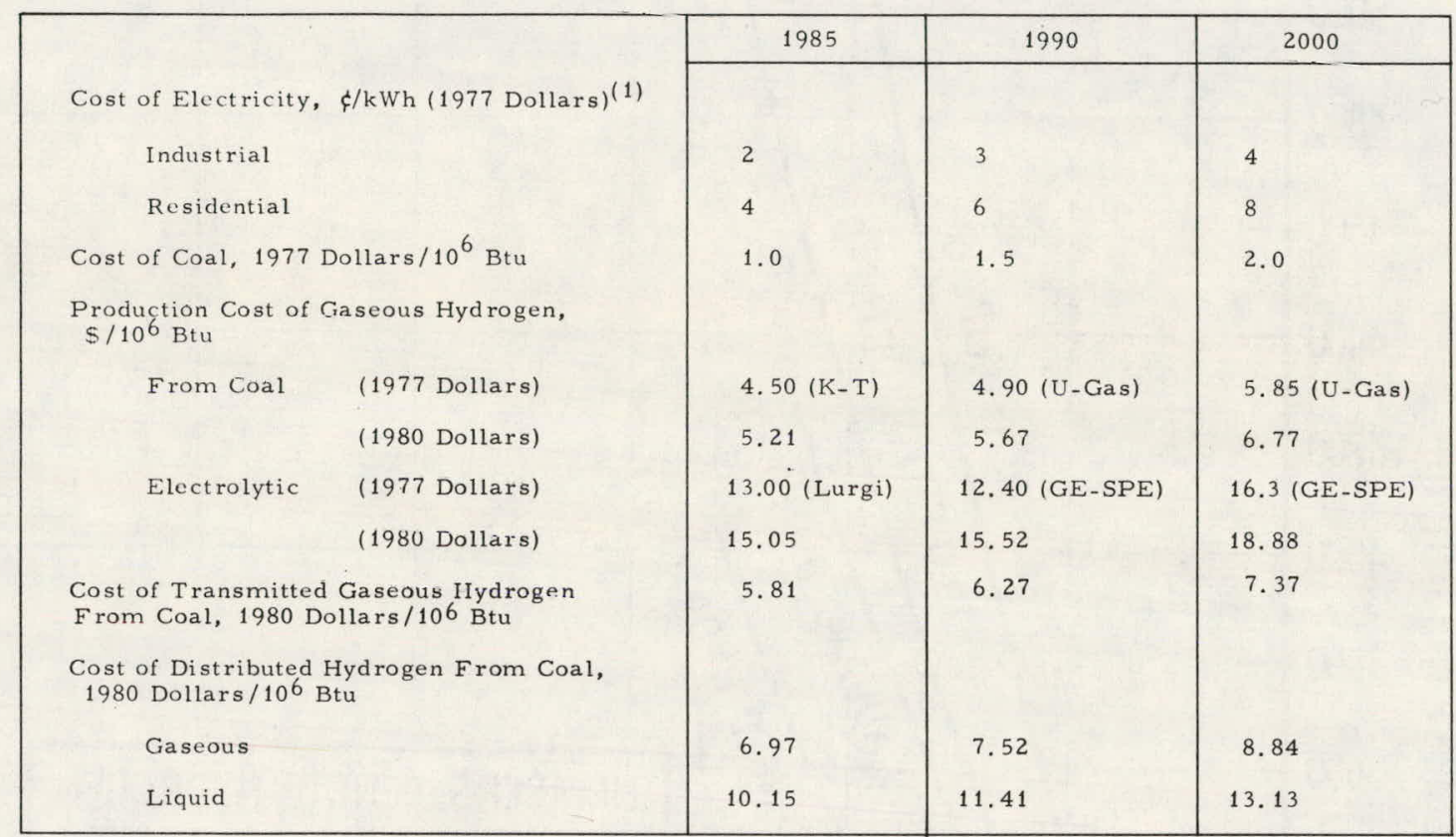

(1) $\xi / \mathrm{kWh} \times 2.929=\$ / 10^{6} \mathrm{Btu}$

\subsection{ELECTRIC VEHICLE ANALYSES}

A calculation method was established, and a series of analyses were made for representative batteries in 1985, 1990, and 2000 model year vehicles. Figure 16 shows typical data resulting from the performance analysis for 1985 cars powered by lead/acid batteries. In this case, minimum battery size was established by the $60-\mathrm{mph}$ cruise speed requirement. A new battery, so sized $(887 \mathrm{~kg}$ ), can deliver a $64.2-\mathrm{mi}$ design range (at 70 -percent depth of discharge) and a lifetime mileage of about 57,800 mi (assuming a linear battery capacity decay of 20 percent over battery lifetime). Thus a replacement battery is required to achieve $100,000 \mathrm{mi}$. It is evident that designing the EV to a greater range would substantially increase the weight of an already heavy car (5018-1b test weight $=4718-1 \mathrm{~b}$ curb weight) and increase the combined lifetime mileage of the original and replacement batteries wastefully beyond the $100,000 \mathrm{mi}$ selected for all vehicles. If the design range had 
TABLE 9. TOTAL COST PER MILE FOR HYDROGEN-POWERED CARS

\begin{tabular}{|c|c|c|c|c|c|c|c|c|}
\hline \multirow[b]{2}{*}{ Propul sion System } & \multirow[b]{2}{*}{$\begin{array}{l}\text { Hydrogen } \\
\text { Cost, } \$ / 1 \mathrm{~b}\end{array}$} & \multirow[b]{2}{*}{$\begin{array}{l}\text { Design } \\
\text { Range, mi }\end{array}$} & \multirow[b]{2}{*}{$\begin{array}{c}\text { Energy Cost/ } \\
\mathrm{mi}, \dot{\varepsilon} / \mathrm{mi}\end{array}$} & \multirow[b]{2}{*}{$\begin{array}{l}\text { Total Operating } \\
\left.\text { Cost } / \mathrm{mi}^{2}, \& / \mathrm{mi}^{1}\right)\end{array}$} & \multicolumn{2}{|c|}{ Depreciation Cost $/ \mathrm{mi}, \mathrm{g} / \mathrm{mi}$} & \multicolumn{2}{|c|}{ Total Cost $/ \mathrm{mi}}$, \\
\hline & & & & & $\begin{array}{c}\text { With Hydride } \\
\text { Salvage }(2)\end{array}$ & $\begin{array}{c}\text { W/O Hydride } \\
\text { Selvage }\end{array}$ & $\begin{array}{l}\text { With Hydride } \\
\text { Salvage }\end{array}$ & $\begin{array}{c}\text { W/O Hydride } \\
\text { Salvage }\end{array}$ \\
\hline 1985 Liquid Hydrogen & 0.524 & $\begin{array}{r}85 \\
200\end{array}$ & $\begin{array}{l}2.7 \\
2.7\end{array}$ & $\begin{array}{l}8.2 \\
8.2\end{array}$ & $\begin{array}{l}- \\
-\end{array}$ & $\begin{array}{l}4.8 \\
5.4\end{array}$ & $\begin{array}{l}- \\
-\end{array}$ & $\begin{array}{l}13.0 \\
13.6\end{array}$ \\
\hline $\begin{array}{l}1985 \text { Iron-Titanium } \\
\text { Hydride }\end{array}$ & 0.360 & $\begin{array}{r}85 \\
200\end{array}$ & $\begin{array}{l}2.1 \\
\text { 3. } 0\end{array}$ & $\begin{array}{l}7.6 \\
8.5\end{array}$ & $\begin{array}{r}8.1 \\
17.7\end{array}$ & $\begin{array}{r}8.9 \\
20.4\end{array}$ & $\begin{array}{l}15.6 \\
26.2\end{array}$ & $\begin{array}{l}16.4 \\
28.9\end{array}$ \\
\hline 1990 Liquid Hydrogen & 0.589 & $\begin{array}{r}85 \\
200\end{array}$ & $\begin{array}{l}2.0 \\
2.1\end{array}$ & $\begin{array}{l}7.5 \\
7.6\end{array}$ & - & $\begin{array}{l}4 . ? \\
5 .\end{array}$ & - & $\begin{array}{l}12.2 \\
12.7\end{array}$ \\
\hline $\begin{array}{l}1990 \text { Iron-Titanium } \\
\text { Hydride }\end{array}$ & 0.388 & $\begin{array}{r}85 \\
200\end{array}$ & $\begin{array}{l}1.9 \\
2.4\end{array}$ & $\begin{array}{l}7.4 \\
7.9\end{array}$ & $\begin{array}{r}7.3 \\
13.3\end{array}$ & $\begin{array}{r}7 . \stackrel{a}{1} \\
15.1\end{array}$ & $\begin{array}{l}14.7 \\
21.2\end{array}$ & $\begin{array}{l}15.3 \\
23.0\end{array}$ \\
\hline 1990 Advanced Hydride & 0.388 & $\begin{array}{r}85 \\
200\end{array}$ & $\begin{array}{l}2.3 \\
2.9\end{array}$ & $\begin{array}{l}8.3 \\
8.9\end{array}$ & $\begin{array}{r}7.0 \\
12.4\end{array}$ & $\begin{array}{r}7.1 \\
12.5\end{array}$ & $\begin{array}{l}15.3 \\
21.3\end{array}$ & $\begin{array}{l}15.4 \\
21.4\end{array}$ \\
\hline 2000 Liquid Hydrogen & 0.678 & $\begin{array}{r}85 \\
200\end{array}$ & $\begin{array}{l}2.0 \\
2.1\end{array}$ & $\begin{array}{l}7.5 \\
7.6\end{array}$ & - & $\begin{array}{l}4.2 \\
4.6\end{array}$ & - & $\begin{array}{l}11.7 \\
12.2\end{array}$ \\
\hline 2000 Advanced Hydride & 0.456 & $\begin{array}{r}85 \\
200\end{array}$ & $\begin{array}{l}2.3 \\
2.8\end{array}$ & $\begin{array}{l}8.3 \\
8.8\end{array}$ & $\begin{array}{r}6.1 \\
10.5\end{array}$ & $\begin{array}{r}6.1 \\
10.6\end{array}$ & $\begin{array}{l}14.4 \\
19.3\end{array}$ & $\begin{array}{l}14.4 \\
19.4\end{array}$ \\
\hline
\end{tabular}

(1) Total operating cost $/ \mathrm{mi}=$ hydrogen energy cost $/ \mathrm{mi}+$ taxes, registration, and insurance of $4 \xi / \mathrm{mi}+$ repairs, maintenance, tires, accessories, and oil cost of $1.5 \mathrm{\xi} / \mathrm{mi}$ for liquid hydrogen and iron-titanium hydride cars and $2 \xi / \mathrm{mi}$ for advanced hydride cars.

(2) Assumed salvage values of metal hydrides: iron-titanium hydride $\$ 2.00 / 1 \mathrm{~b}$, advanced hydride $\$ 0.50 / 1 \mathrm{~b}$. 


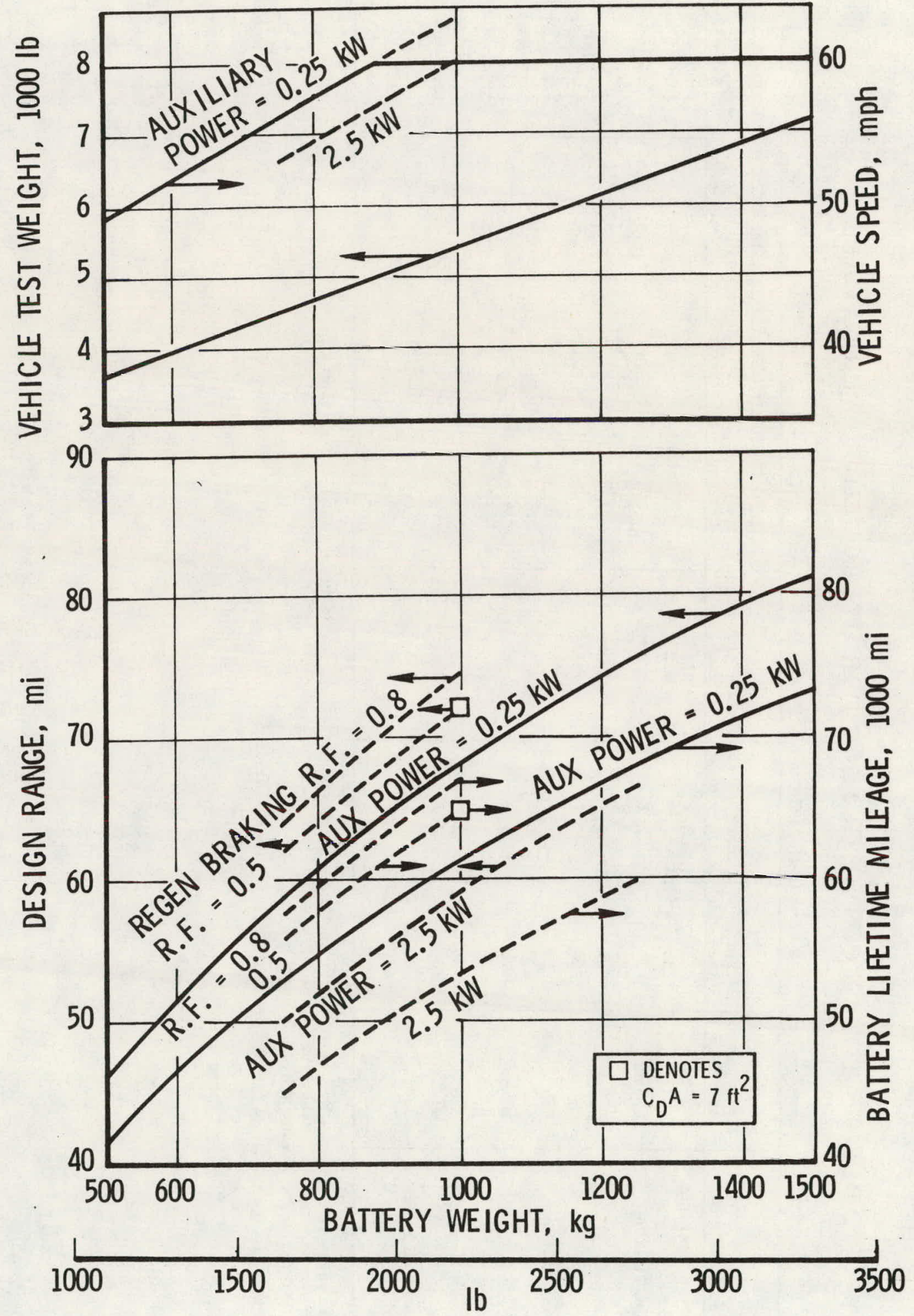

FIGURE 16. 1985 MODEL. YEAR ELECTRIC VEHICLE CHARACTERISTICS - LEAD/ACID BATTERY 
to be higher than $64 \mathrm{mi}$, it would be prudent to try to reduce battery specific weight and cost per unit capacity by reducing cycle life requirements.

In Figure 16, the effects of increasing auxiliary power load from $0.25 \mathrm{~kW}$ to $2.50 \mathrm{~kW}$ (as might be necessary when heating or air conditioning is included) are shown for vehicle speed, design range, and lifetime mileage. The effects on design range and lifetime mileage are also shown for two values of energy recovery factor (RF) for regenerative braking and a reduction in the product of aerodynamic drag coefficient and frontal area $\left(C_{d} A\right)$ from $8 \mathrm{ft}^{2}$ to $7 \mathrm{ft}^{2}$.

Table 10 presents data for all EV's designed to their minimum ranges. The different ranges result from battery sizing that satisfies all of the following performance requirements: 60 -mph cruise speed, peak power required by the driving cycle acceleration, and a lifetime mileage of 100,000 mi on one or two batteries (assuming a linear 20-percent decay of battery storage capacity over the stated battery cycle life). The vehicle weights were obtained by appropriate modifications to a published procedure for gasolinefueled cars (Ref. 26). In addition to replacement of the ICE and its exhaust system with an electric motor, its controller, and cabling, the weight analysis includes provision for the major change in energy storage-dependent weight. For the EV, this includes the battery, its charger, thermal control provisions (if needed to isolate the battery from vehicle structure), and a vehicle weight increment dependent upon the volume occupied by the battery.

The batteries of the 1985 cars are seen to have peak power capabilities substantially above the driving cycle requirement of $0.014 \mathrm{hp} / \mathrm{lb}$ of vehicle test weight. If equipped with larger motors and controllers, the horsepower-to-weight ratio of approximately 0.025 for these vehicles would enable acceleration comparable to many conventional cars. The 1990 and 2000 model year cars, however, might also require increases in battery weight with resultant increases in vehicle weight, cost, size, and design range. The increases need not be large to exceed the performances of the current Mercedes $240 \mathrm{D}$ and Volkswagen Rabbit diesel engine cars with values of 0.0177 $\mathrm{hp} / \mathrm{lb}$ and $0.0213 \mathrm{hp} / \mathrm{lb}$, respectively. 
TABLE 10. SUMMARY OF ELECTRIC VEHICLE DESIGN AND PERFORMANCE CHARACTERISTICS

\begin{tabular}{|c|c|c|c|c|}
\hline Model Year & 1985 & 1985 & 1990 & 2000 \\
\hline Battery & Lead/Acid & Nickel/Zinc & $\begin{array}{l}\text { Zind } \\
\text { Chlorine } \\
\text { Hydrate }\end{array}$ & $\begin{array}{l}\text { Lithium- } \\
\text { Aluminium/ } \\
\text { Iron Sulfide }\end{array}$ \\
\hline No. Batteries Required for $100,000 \mathrm{mi}$ & 2 & 2 & 1 & 1 \\
\hline Battery Weight, $\mathrm{kg} / \mathrm{lb}$ & $887 / 1956$ & $500 / 1102$ & $358 / 789$ & $175 / 386$ \\
\hline $\begin{array}{l}\text { Vehicle Resistance Characteristics, } \\
C_{R} / C_{D^{A}},(1 b / 1 b) / \mathrm{ft}^{2}\end{array}$ & $0.012 / 8$ & $0.012 / 8$ & $0.010 / 7$ & $0.008 / 6$ \\
\hline Vehicle Test Weight, WT, lb & 5018 & 3799 & 3553 & 2449 \\
\hline Vehicle Miles/Battery, mi & 57,790 & 50,900 & 100,000 & 100,510 \\
\hline Battery Capacity, kWh & 44.3 & 45 & 53.7 & 30.6 \\
\hline $\begin{array}{l}\text { Design Range for } 0.25 \mathrm{~kW} \text { Accessory } \\
\text { Power Load, mili) }\end{array}$ & 64.2 & 80.8 & 111.1 & 93.1 \\
\hline Usefulness Factor, \% of Days of Year & 91.3 & 94.6 & 96.5 & 96.0 \\
\hline Range Penalty for $2.5 \mathrm{~kW}$ Power Load, $\mathrm{mi} / \tau_{0}$ & $7.0 / 14.1$ & $13.7 / 17.0$ & $22.1 / 19.9$ & $23.72 / 25.5$ \\
\hline $\begin{array}{l}\text { Range Increase with Regenerative Braking, } \mathrm{mi} / \% \\
\text { Recovery Factor }=0.5 \\
\text { Recovery Factor }=0.8\end{array}$ & $\begin{array}{l}3.5 / 5.5 \\
5.8 / 9.0\end{array}$ & $\begin{array}{l}3.9 / 4.3 \\
6.5 / 8.0\end{array}$ & $\begin{array}{l}5.9 / 5.3^{(2)} \\
9.7 / 8.7\end{array}$ & $\begin{array}{l}7.2 / 7.7 \\
12.1 / 13.0\end{array}$ \\
\hline Drive Motor Rated Horsepower @ $60 \mathrm{mph}, \mathrm{h}_{\mathrm{R}}$ & 25.31 & 22.55 & 18.86 & 14.06 \\
\hline Driving Cycle Peak Motor Horsepower, $\mathrm{hp}_{\mathrm{P}}$ & 68.76 & 53.43 & 48.5 & 33.57 \\
\hline $\mathrm{hp}_{\mathrm{P}} / \mathrm{WT}$ & 0.0137 & 0.0141 & 0.0137 & 0.0137 \\
\hline Battery-Limited $h \mathrm{p}_{\mathrm{p}} / \mathrm{WT}$ & 0.0257 & 0.0255 & 0.10148 & 0.0172 \\
\hline Vehicle Length Increase Over Gasoline Powered Car, in. & 26.1 & 18.4 & 23.1 & 8.6 \\
\hline
\end{tabular}

(1) Society of Autcmotive Engineers J227a, Schedule D Driving Cycle.

(2) Not currently feasible without on-board chiller for hydrate ice.

${ }^{(3)}$ Gasoline engine powered four-passenger car (Ref. 26):

$1980-1990:$ 1) hp $/ \mathrm{WT}=0.015$, WT $=2239 \mathrm{lb}, 2) \mathrm{hp} / \mathrm{WT}=0.030, \mathrm{WT}=2293 \mathrm{lb}$

$2000:$ 1) hp: $W T=0.015, W T=2048 \mathrm{lb}, 2) \mathrm{hp} / \mathrm{Wt}=0.030, \mathrm{WT}=2097 \mathrm{lb}$

Length $=159.5$ in., Wheelbase $=97.0$ in., Height $=53.0$ in., Width $=60.8$ in. 
Costs of EV's were estimated, in 1980 dollars, typically using a range of original equipment manufacturer (OEM) battery costs from $\$ 40$ to $\$ 60 / \mathrm{kWh}$. Vehicle prices to the customer were estimated considering replacement batteries for 1985 model year cars. Investment costs minus salvage values were simply prorated over $100,000 \mathrm{mi}$ for all vehicles to obtain depreciation cost per mile. Battery charging requirements were estimated including energy cost for two levels of power snst: $4 \notin$ and $8 \notin / \mathrm{kWh}$. A fixed allowance of $5.5 \notin / \mathrm{mi}$ was made to cover repairs, maintenance, tires, accessories, lubricants, taxes, registration, and insurance (Ref, 27). Table 11 summarizes these cost estimates leading to the resultant total costs of ownership. It is seen that, even if current power costs double from about $4 \notin / \mathrm{kWh}$, the EV of the year 2000 should cost less to recharge than a $1985 \mathrm{EV}$. The total ownership cost advantage of the year 2000 car is even greater due primarily to reduced vehicle weight and avoidance of battery replacement. It should be noted that some forecasts limit battery life to about 5 years because of corrosion and other forms of deterioration. If this is true, the 1990 and 2000 model year EV's would have to be operated at about twice the average annual mileage of current automobiles to obtain the advantages over near-term EV's determined in this study. Alternatively, battery cycle life, specific weight, and specific cost could be reduced to offset the cost of a replacement battery, resulting in an ownership cost increase of $0.5 \notin$ to $1.5 \notin / \mathrm{mi}$.

5.4

COMPARISON OF VEHICLES

Figure 17 is representative of comparisons of $\mathrm{HV}$ and $\mathrm{EV}$ weights and lengths, made for each of three model years. Typically high weight and length sensitivities of EV's to design range are illustrated. The vehicle length increment is a theoretical allowance for the volume of the energy storage system assuming that it occupies the entire vehicle cross section above the floor panel and below the window level.

A meaningful comparison of vehicles requires that they have approximately equivalent performance and mission usefulness. The measure of usefulness is the percentage of the number of days of the year that all 
TABLE 11. TOTAL COST PER MILE FOR BATTERY-POWERED CARS

\begin{tabular}{|c|c|c|c|c|}
\hline \multirow[b]{2}{*}{ Characteristics and Costs } & \multicolumn{4}{|c|}{ BATTERY } \\
\hline & $\begin{array}{c}1985 \\
\text { Lead/Acid }\end{array}$ & $\begin{array}{c}1985 \\
\text { Nickel/Zinc }\end{array}$ & $\begin{array}{l}1990 \mathrm{Zinc} / \\
\text { Chlorine Hydrate }\end{array}$ & $\begin{array}{l}2000 \text { Lithium- } \\
\text { Aluminum/Iron } \\
\text { Sulfide. }\end{array}$ \\
\hline Capacity, kWh & 44.3 & 45 & 53.7 & 30.6 \\
\hline Design Range, mi & 64.2 & 80.8 & 111.1 & 93.1 \\
\hline $\begin{array}{l}\text { Efficiencies of Battery and } \\
\text { Charger, } \%\end{array}$ & $7 c_{i} / 90$ & $70 / 90$ & $65 / 90$ & $90 / 90$ \\
\hline $\begin{array}{l}\text { Charge Energy @ } 70 \% \text { Depth } \\
\text { of Discinarge, kWh }\end{array}$ & 49.2 & 50.0 & 64.3 & 26.4 \\
\hline Charges/100,000 $\mathrm{mi}^{(1)}$ & 1730 & 1375 & 1000 & 1193 \\
\hline $\begin{array}{l}\text { Charge Ene rgy Cost at } 4 \xi / \\
\mathrm{kWh} \text { and } 8 \xi / \mathrm{kWh}, \xi / \mathrm{mi}(1)\end{array}$ & $3.4 / 6.8$ & $2.8 / 5.5$ & $2.6 / 5.1$. & $1.3 / 2.5$ \\
\hline Total Operating Cost $\xi / \mathrm{mi}^{(2)}$ & $8.9 / 12.3$ & $8.2 / 11.0$ & $8.1 / 10.6$ & $6.8 / 8.0$ \\
\hline $\begin{array}{l}\text { Battery Cost, } \$ / \mathrm{kWh} \\
\text { (1.980 Dollars) }\end{array}$ & 40 & $50-60$ & $50-60$ & $40-60$ \\
\hline $\begin{array}{l}\text { Vehicle Depreciation Including } \\
\text { Salvage, } \phi / \mathrm{mi}\end{array}$ & 9.2 & $9.6-10.6$ & $7.9-8.6$ & $4.9-5.6$ \\
\hline Cost of Ownership, $\xi / \mathrm{mi}$ & & & & \\
\hline $\begin{array}{l}\text { Power Cost }=4 \xi / \mathrm{kWh} \\
\text { Power Cost }=8 \xi / \mathrm{kWh}\end{array}$ & $\begin{array}{l}18.1 \\
21.5\end{array}$ & $\begin{array}{l}17.8-18.8 \\
20.6-21.6\end{array}$ & $\begin{array}{l}16.0-16.7 \\
18.5-19.2\end{array}$ & $\begin{array}{l}11.6-12.4 \\
12.9-13.6\end{array}$ \\
\hline
\end{tabular}

(1) Assumes vehicle has 100,000-mi lifetime with battery output declining linearly by 20 percent over the battery cycle life.

(2)

Includes costs of charging energy plus $5.5 \xi / \mathrm{mi}$ for repairs, maintenance, tires, accessories, oil, taxes, registration, and insurance (Ref. 27). 


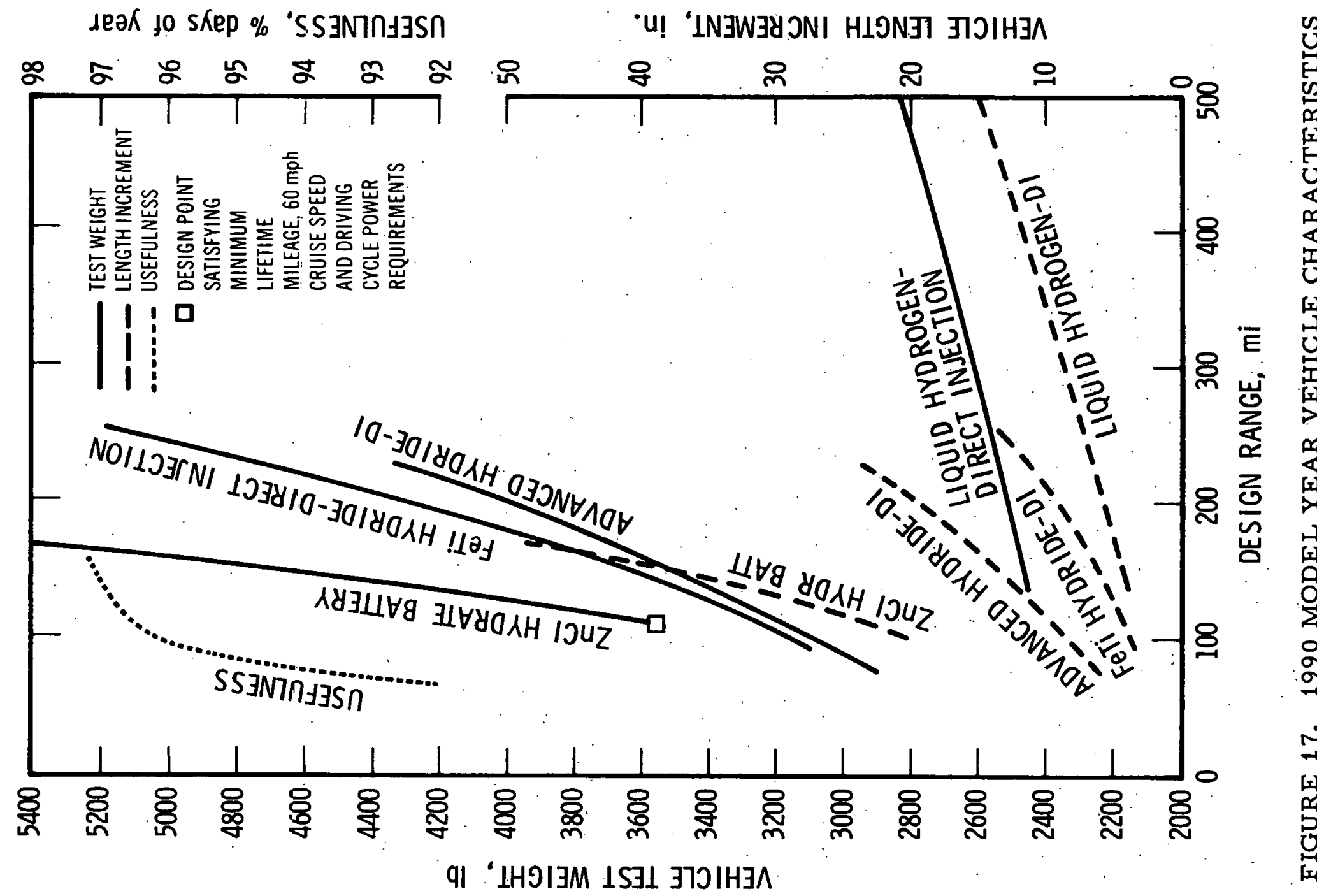


driving requirements (total travel distance) can be satisfied by the range capability of the vehicle on a single energy charge. A value of about 95 percent is believed necessary to give a vehicle sufficient utility to warrant its purchase by a typical driver. The corresponding daily mileage is $83 \mathrm{mi}$ (Ref. 28). Clearly, some people could settle for less, especially in a second car, and others would insist on more. Tabulated data for HV's in this study always include an 85-mi design case. The design constraints for the EV's studied cause them to have minimum design ranges from 64 to $111 \mathrm{mi}$, with usefulness values of 91 to 96.5 percent. These values are sufficiently close to the values chosen for the $\mathrm{HV}^{\prime} \mathrm{s}$ that they can be meaningfully compared, without burdening the EV's with batteries suitable for more than the prescribed. 100,000-mi lifetime mileage. Tabulated data, as in Table 9, sometimes include a $200-\mathrm{mi}$ design range case (with usefulness values of more than 97 percent). This is intended to show the sensitivities of vehicle design and cost to choice of a range near the practical limit for many of the vehicle types under consideration. Table 12 presents weight and cost estimates for minimum design range HV's and $E V^{\prime}$ 's as discussed above. Vehicle purchase price in 1980 dollars clearly favors LSHV's for the time periods studied. The initial cost disadvantage of near-term EV's is further aggravated by the need to purchase a replacement battery to attain a 100,000-mi operating lifetime.

6.

SOURCE ENERGY CONVERSION AND

TRANSFER EFFICIENCIES

The major fossil and nonfossil energy sources for electricity and hydrogen prior to the year 2000 are identified, and estimates are made for the efficiencies of all the major steps in their logistic chains in Tables 13 , 14, and 15. The first step, presented in Table 13, includes conversion processes to electricity or hydrogen and possible subsequent electrolysis or liquefaction processes (Refs. 29, 30). The next step is the transfer of the converted energy by suitable transmission, storage, and distribution modes. A storage phase is anticipated involving the entire quantity of liquid hydrogen transmitted. For electricity and gaseous hydrogen, only a small fraction of 
TABLE 12. WEIGHTS AND COSTS OF MINIMUM RANGE FOUR-PASSENGER CARS

\begin{tabular}{|c|c|c|c|c|c|c|c|c|c|c|c|}
\hline Energy Storage System Tyae & & uid Hydro & & Iron-Titanit & Hydride & Advanc & Hydride. & Lead $/ f$.cid & Nickel/Zinc & $\begin{array}{l}\text { Zinc/Chlo:ine } \\
\text { Hydrati: }\end{array}$ & $\begin{array}{l}\text { Lithium- } \\
\text { Aluminum } \\
\text { Aron Sulfide }\end{array}$ \\
\hline Model Year & 1985 & 1990 & 2000 & 1985 & $1990^{\circ}$ & 1990 & 2000 & 1985 & 1985 & 1990 & 2000 \\
\hline Veh:cle Design Range, mi & 85 & 85 & 85 & 85 & 85 & 85 & 85 & 64.2 & 80.8 & 111.1 & 93.1 \\
\hline $\begin{array}{l}\text { Weight of Enc rgy Storage Systen, ib } \\
\text { if Liquidid Hydrogen + Tank 2) Hydride } \\
\text { + Tank 3) Battery }\end{array}$ & 50 & 43 & 41 & 590 & 445 & 275 & 231 & 1956 & 1102 & 789 & 386 \\
\hline 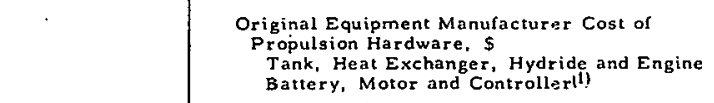 & 1120 & 1170 & 1080 & 4090 & 3420 & 2690 & 2310 & 2210 & $2660-3110$ & $3040-3280$ & 1520.2130 \\
\hline $\begin{array}{l}\text { Vehicle Purchase Price, withost } \\
\text { Transportation and Taxes, } \$ \text { \$ }\end{array}$ & $\cdot 4990$ & 4890 & 4390 & 9110 & 8190. & 7330 & 6330 & 7960 & $7800-8380$ & $8460-9 \infty 0$ & $5160-5950$ \\
\hline $\begin{array}{l}\text { Replacement Battery Purchase Price } \\
\text { Allowing Salvage, \$ } \$ \text {. }\end{array}$ & - & - & - & - & - & - & - & $17^{-0}$ & $2250-2700$ & 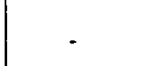 & - \\
\hline Total Investment, $\$$ & 4980 & 4900 & 4390 & 9110 & 8190 & 7330 & 6330 & $96 \div 0$ & $0,050-11,080$ & $8460-910.0$ & $5150-5950$ \\
\hline Vehicle Salvage Value $(\pi 100,0.00 \mathrm{mi}, \mathrm{s}$ & 220 & 210 & 190 & $250-1050$ & $240-840$ & $260-310$ & $230-270$ & 450 & $460-510$ & $520-570^{\circ}$ & $300-360$ \\
\hline
\end{tabular}
(1) Battery costs/kWh: Lead/acił $-\$ 40$, nickel/zinc $-\$ 50-\$ 60$, zinc/chlorine hydrate $-\$ 50-\$ 60$, Lithium.
alaminum/iron sulfide $-\$ 40-\$ 60$. 
TABLE 13. CONVERSION PROCESS EFFICIENCIES

\begin{tabular}{|c|c|c|c|}
\hline Energy Sources & Generation of Electricity & Generation of Hydrogen & $\begin{array}{l}\text { Liquefaction of } \\
\text { Hydrogen }\end{array}$ \\
\hline \multicolumn{4}{|l|}{ Fossil } \\
\hline F'etroleum & 0.39 (Steam Turbine Plant) & $\begin{array}{l}<0.74 \text { (Partial Oxidation and } \\
\text { Steam Reformation) }\end{array}$ & $\begin{array}{ll}\text { 1985: } & 0.754 \\
1990: & 0.76 \\
2000: & 0.773\end{array}$ \\
\hline Natural Gas & 0.39 (Steam Turbine Plant) & 0.74 (Steam Reformation) & \\
\hline Coal & 0.37 (Steam Turbine Plant) & $\begin{array}{l}\text { 1980-1985: 0.57 (Koppers-Totzek) } \\
\text { 1990:0.63 (Steam-Iron) } \\
\text { 2000:0.66 (U-Gas) }\end{array}$ & . \\
\hline Shale Oil & 0.39 (Steam Turbine Plant) & $\begin{array}{l}<0.74 \text { (Partial Oxidation and } \\
\text { Steam Reformation) }\end{array}$ & \\
\hline \multicolumn{4}{|l|}{ Nonfossil } \\
\hline Nuclear & $\begin{array}{l}\text { 1980-1985:0.31 (LWR); 1990: 0.33 } \\
\text { 2000: 0.40 (Gas Turbine Cycle), } \\
0.50 \text { (Bottoming Cycle) }\end{array}$ & $\begin{array}{cc}\text { 1980-1985: } & 0.79 \text { (Electrolysis) } \\
1990-2000: & 0.865 \text { (Electrolysis) }\end{array}$ & \\
\hline Hydro & 0.85 (Turbine Plant) & & \\
\hline Solar & $\begin{array}{l}0.17 \text { (Paraboloidal Dish, Steam } \\
\text { Turbine); } 0.19 \text { (Central Receiver, } \\
\text { Steam Turbine) }[30]^{(1)}\end{array}$ & ${ }^{-}$ & \\
\hline Wind & 0.40 & 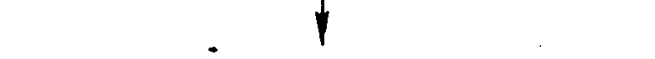 & . \\
\hline Geothermal & $\begin{array}{l}0.84 \text { (Organic Fluid-Rankine } \\
\text { Cycle Turbine Plant) }[29](1)\end{array}$ & $\begin{array}{l}<0.74 \text { (Steam Reformation of } \\
\mathrm{CH}_{4} \text { Content). }\end{array}$ & \\
\hline Solid Waste & $\begin{array}{l}0.25 \text { (Combined with Coal-Fired } \\
\text { Steam Turbine Plant)(Propor- } \\
\text { tioned to Reference } 29 \text { Data) }\end{array}$ & $\begin{array}{l}0.79,0.865 \text { (Electrolysis) } \\
<.74 \text { (Partial Oxidation) }\end{array}$ & $\downarrow$ \\
\hline
\end{tabular}

(1) []$=$ reference numbers. 
TABLE 14. ENERGY TRANSPORT AND STORAGE EFFICIENCY ASSUMPTIONS

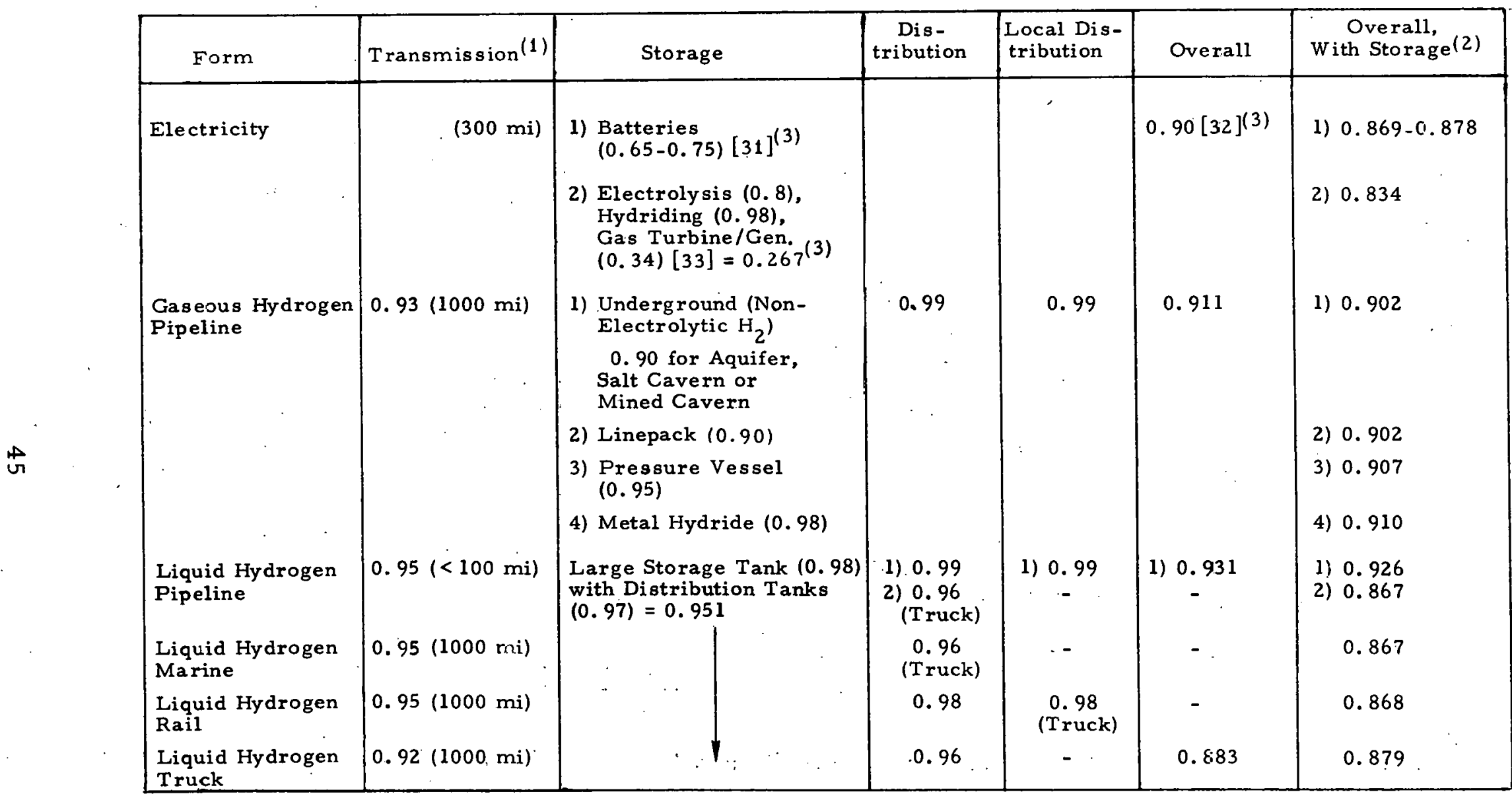

(1) Nominal transmission distances in parentheses.

${ }^{(2)}$ Storage capacity assumed equal to 10 percent of annual consumption; based on relatively consistent automotive demand compared to highly seasonal natural gas usage, which required 25 percent storage capacity.

${ }^{(3)}[]=$ reference numbers. 
TABLE 15. VEHICLE ENERGY CHARGING EFFICIENCY

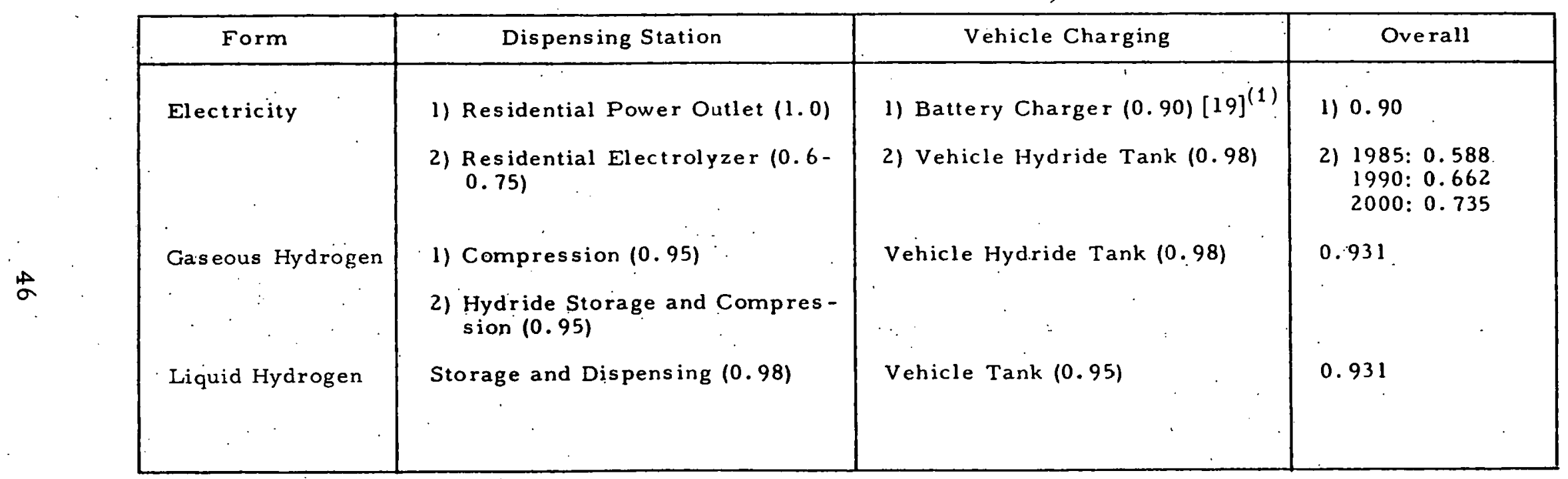

(1) []$=$ reference number. 
the energy required by the automotive sector need be stored, and various means of doing this were considered. Estimated efficiencies for the alternatives are given in Table 14 (Refs. 31, 32, 33). The final step, presented in Table 15, is the storage and dispensing of hydrogen into vehicle tanks at a service station or the application of electricity at the location where the vehicle is kept overnight (Ref. 19). Electricity could be applied to a battery charger or to an electrolyzer used to generate hydrogen for charging directly into a vehicle hydride tank.

Table 16 is the tabulation of the estimated efficiencies of all significant steps in the logistic chain from a coal source (excluding mining and coal transportation) to the vehicle input. Six major standard options are identified based upon the sequence leading to the product that is transmitted and upon whether the product is further converted at the point of use. The most efficient sequence from coal to vehicle input, as expected, includes coal gasification and vehicle hydride tank charging. Similar tables were prepared for the other energy sources. Table 17 is a summary table for the most viable options for obtaining electricity and gaseous and liquid hydrogen in the year 2000. From an energy efficiency standpoint, Table 17 shows that electricity should be generated from hydro, geothermal, and nuclear sources and that hydrogen should be obtained from coal gasification and either direct gasification of shale or partial oxidation of shale oil.

7.

OVERALL SOURCE ENERGY UTILIZATION

The vehicle energy consumption characteristics and the overall efficiencies of source energy. conversion, transport, storage, and dispensing were combined to obtain the source energy consumption per vehicle mile traveled. Table 18 illustrates one of many resultant comparisons made between HV's and EV's, this one being for the 1990 model year assuming coal as the energy source. At the selected minimum design range, it is seen that the EV requires the least input energy. This was observed at each time period studied. However, in 1990, the LSHV consumes the least source energy, followed by iron-titanium and advanced hydride HV's and the 
TABLE 16. EFFICIENCY OF PROCESSES FROM ENERGY SOURCE TO VEHIC LE ENERGY STORAGE INPUT - ENERGY SOURCE: COAL

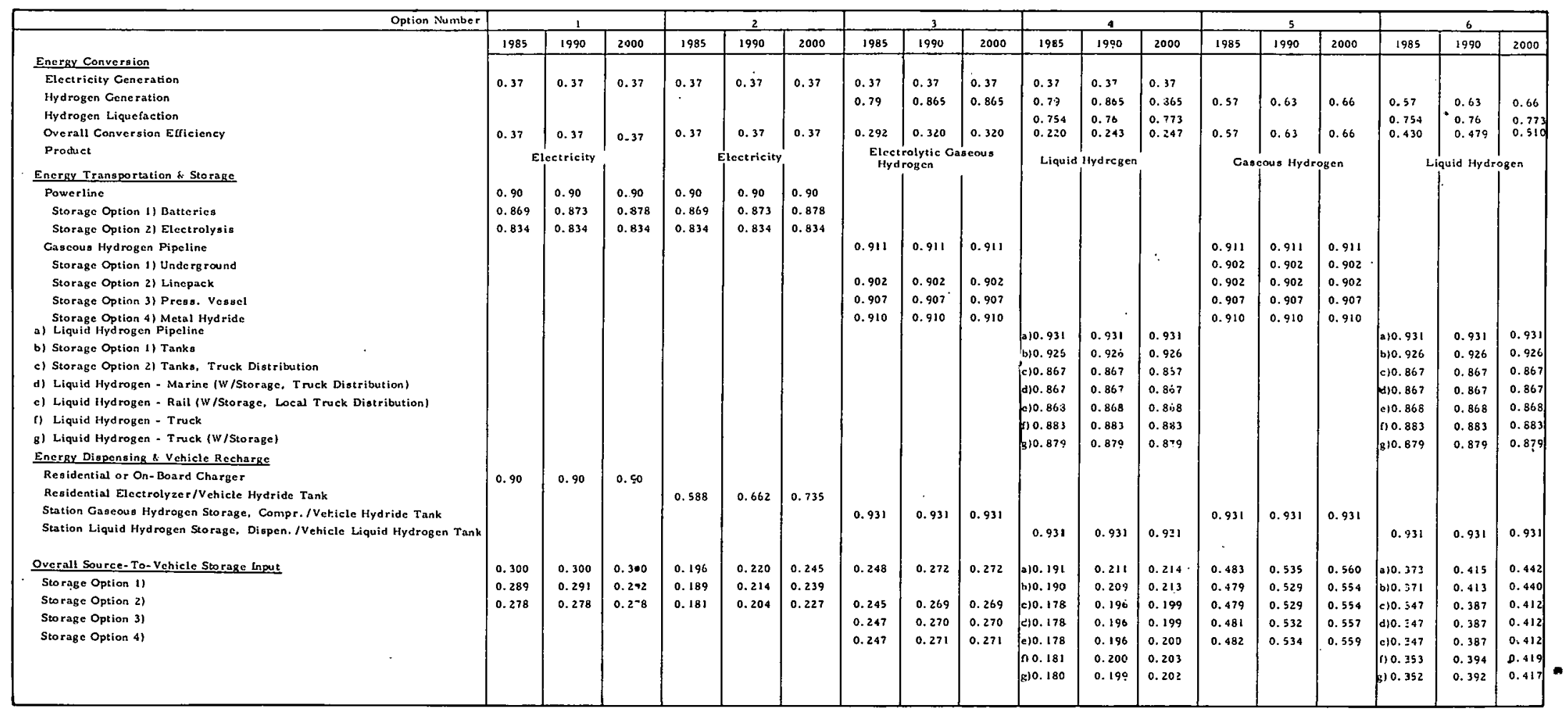


TABLE 17. EFFICIENCY OF PROCESSES FROM ENERGY SOURCE TO VEHICLE ENERGY STORAGE INPUT - YEAR 2000

\begin{tabular}{|c|c|c|c|c|c|c|c|c|c|c|c|c|}
\hline \multirow{2}{*}{$\begin{array}{l}\text { Sources } \\
\text { Options }\end{array}$} & \multicolumn{3}{|c|}{ Coal } & \multicolumn{3}{|c|}{ Nuclear ${ }^{(1)}$} & \multicolumn{3}{|c|}{$\begin{array}{l}\text { Natural Gas } \\
\text { Petroleum, Stale } \\
\text { Oil and Wing }\end{array}$} & \multicolumn{3}{|c|}{$\begin{array}{l}\text { Hydro and } \\
\text { Geotiermal }\end{array}$} \\
\hline & 1 & 5 & 6 & 1 & 3 & 4 & 1 & 5 & 6 & 1 & 3 & 4 \\
\hline Products & Elec. & $\begin{array}{c}\begin{array}{c}\text { Gaseous } \\
\text { Hydrogen }\end{array} \\
\end{array}$ & $\begin{array}{c}\text { Liquid } \\
\text { Hydrogen }\end{array}$ & Elec. & $\begin{array}{l}\begin{array}{c}\text { Gaseous } \\
\text { Hyd rogen }\end{array} \\
\end{array}$ & $\begin{array}{c}\text { Liquid } \\
\text { Hyd rogen }\end{array}$ & Elec. & $\begin{array}{c}\text { Gaseous } \\
\text { Hydrogen }\end{array}$ & \begin{tabular}{|c|} 
Liquid \\
:Hydrogen \\
\end{tabular} & Elec. & $\begin{array}{l}\text { Gaseous } \\
\text { Hydrogen }\end{array}$ & \begin{tabular}{|c|} 
Liquid \\
Hydrogen
\end{tabular} \\
\hline Overall Energy Conversion & 0.37 & 0.66 & 0.51 & 0.40 .5 & $\frac{0.346}{0.433}$ & $\frac{0.267}{0.334}$ & 0.39 & 0.74 & 0.572 & 0.85 & 0.735 & 0.568 \\
\hline Energy Transmission and Distribution & & & & & & & & & & & & \\
\hline Pawerline or Pipeline & 0.90 & 0.911 & 0.931 & 0.90 & 0.911 & 0.931 & 0.90 & 0.911 & 0.931 & 0.90 & .911 & 0.931 \\
\hline With $10 \%$ Energy Storage & 0.878 & 0.910 & 0.926 & 0.878 & 0.910 & 0.926 & 0.878 & 0.910 & 0.926 & 0.878 & 2.910 & 0.926 \\
\hline $\begin{array}{l}\text { Energy Dispensing and Vehicle Recharge } \\
\text { Battery Charger }\end{array}$ & 0.90 & & & 0.90 & & . & 090 & & & 0 & & \\
\hline $\begin{array}{l}\text { Station Storage, Compression, Dispensing, } \\
\text { Vehicle Charging }\end{array}$ & & 0.931 & .0 .931 & & 0.931 & 0.931 & & 0.931 & 0.931 & & 0.931 & 0.931 \\
\hline Overall Source-to-Vehicle Storage Input & 0.300 & 0.560 & 0.442 & $\frac{0.324}{0.405}$ & $\frac{0.293}{0.367}$ & $\frac{0.232}{0.290}$ & 0.316 & 0.628 & 0.456 & 0.689 & 0.624 & 0.493 \\
\hline
\end{tabular}

(1) Nuclear electricity generation efficiencies in 2000 are assumed to be 0.40 (Simple Turbine Cycle) and 0.50 (Bottoming Turbine Cycle). 
TABLE 18. 1990 MODEL YEAR VEHICLE ENERGY COMPARISONS ENERGY SOURCE: COAL

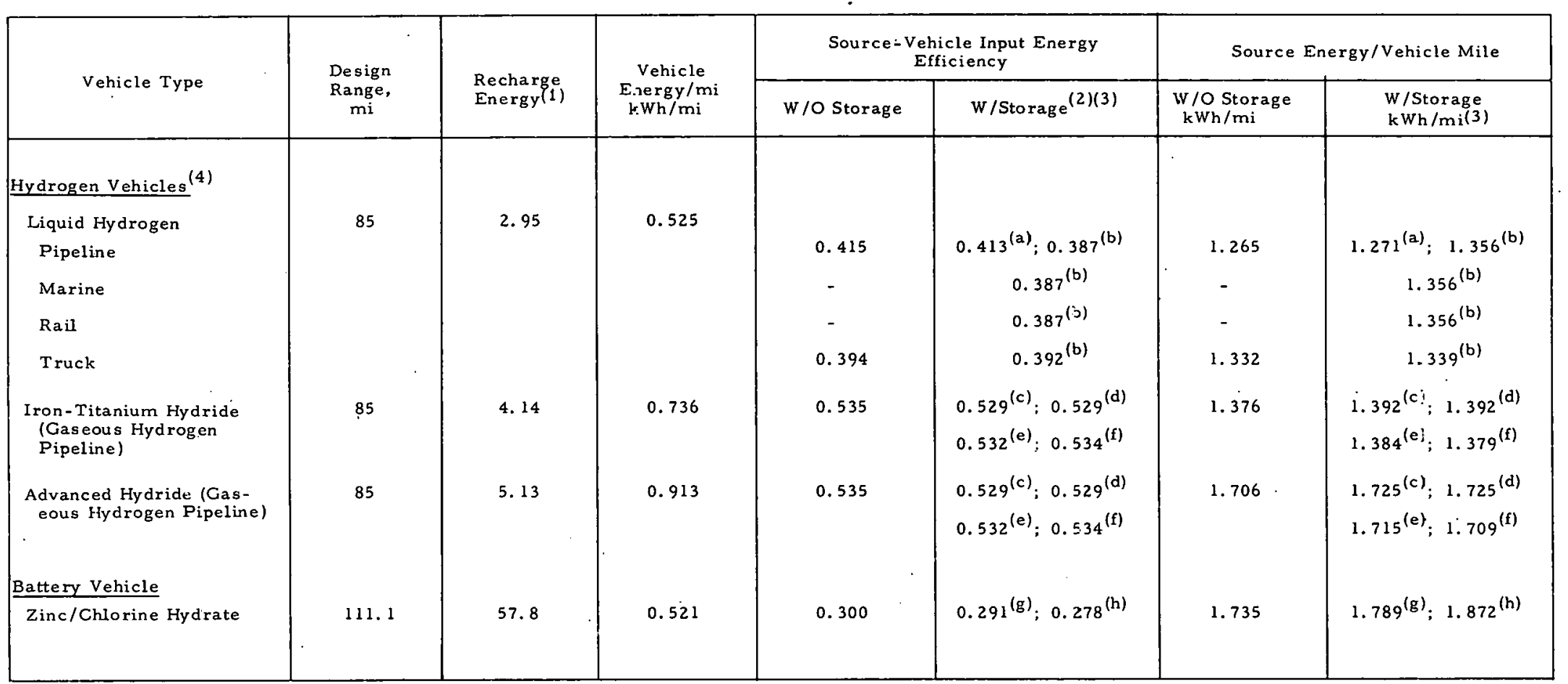

(1) Recharge Energy:

Hydrogen refill weight in $1 \mathrm{~b}=\mathrm{Cx}$ Capacity; $\mathrm{C}=0.90$ and 0.95 for liquid hydrogen in 1985 and later, respectively: $\mathrm{C}=0.80$ for iron-titanium

in $\mathrm{kWh}=$ depth of discharge $x$ capacity/battery efficiency.

(2) Nonessential energy storage $=10 \%$ of directly transmitted energy.

(3) Storage and distribution options:
(a) Liquid hydrogen tank; (b) Liquid hydrogen tank and truck distribution; ${ }^{(c)}$ Underground;

$(\mathrm{g})_{\text {Batteries; }}{ }^{(\mathrm{h})}$ Electrolytic hydrogen stored in hydride until used to fuel turbogenerator.

${ }^{(4)}$ Hydrogen assumed derived from coal gasification because of mach highef efficiency than for industrial or residential electrolysis. 
zinc/chlorine hydrate FV. The spread in source energy utilization is from 1.27 to $1.74 \mathrm{kWh} / \mathrm{mi}$ without transmission storage.

A broader picture of overall source energy consumption can be obtained by not considering the relatively minor effects of energy storage in the logistic chain and the multiplicity of transportation options. Table 19 focuses on the most efficient use of each energy source considered in satis fying the energy needs of each vehicle. However, petroleum and oil shale resources were assumed to be used for generation of electricity, whereas their hydrogen production efficiencies, between those of natural gas and coal, make them better suited to hydrogen generation in 19.85 and 1990. In the year 2000, all enèrgy sources are most efficiently used if applied to electricity. generation for the lithium-aluminum/iron sulfide EV. Table 19 also shows that among the HV's, those fueled with liquid hydrogen have the lowest vehicle energy consumptions at all times and are least sensitive to design range. However, in 1985, the iron-titanium hydride HV requires less source energy primarily because of the avoidance of the liquefaction process.

At later times, the LSHV consumes less energy from any source than do the GSHV's. Nuclear reactors require 1.5 to 2.3 times as much fuel energy as do coal conversion plants.

8 . VEHICLE COMPARISON SUMMARY

Table 20 is the final summary comparison of all vehicles investigated. Key characteristics of all minimum design range vehicles are presented along with the implications of increasing the range to $200 \mathrm{mi}$. Principal features projected for each vehicle type considered in this study are presented in the following subsections.

8.1 LIQUID HYDROGEN-FUELED ICE CARS

These vehicles are always the lightest, have the lowest total cost of ownership, are the most suitable for design ranges above the minimum, and have the lowest source energy consumption for the 1990 model year. Because of their small engine size, they are best suited for higher engine 
TABLE 19. COMPARISON OF OVERALL SOURCE ENERGY. CONSUMPTION VERSUS VEHICLE TYPE - MINIMUM DESIGN RANGE

\begin{tabular}{|c|c|c|c|c|c|c|c|c|c|}
\hline \multirow[b]{2}{*}{ Propulsion System } & \multirow{2}{*}{$\begin{array}{c}\text { Vehicle } \\
\text { Input } \\
\text { Energy/ } \\
\mathrm{mi} \\
\mathrm{k} \text { ' } / \mathrm{mi}(1)\end{array}$} & \multicolumn{8}{|c|}{ Overall Source Energy Expenditure/Vehicle Mile, $\mathrm{kWh} / \mathrm{mi}^{(2),(3)}$} \\
\hline & & $\begin{array}{c}\text { Coal } \\
\left(\begin{array}{l}\text { Hydrogen, } \\
\text { Electricity) }\end{array}\right.\end{array}$ & $\begin{array}{c}\text { Nuclear } \\
\text { (Electricity) }\end{array}$ & $\begin{array}{c}\text { Natural } \\
\text { Gas } \\
\text { Hydrogen, } \\
\text { Electricity }\end{array}$ & $\begin{array}{c}\text { Petroleum } \\
\& \\
\text { Shale Oil } \\
\text { (Electricity) }\end{array}$ & $\begin{array}{c}\text { Hydro } \\
\& \\
\text { Geothermal } \\
\text { (Electricity) }\end{array}$ & $\begin{array}{c}\text { Wind } \\
\text { (Electricity) }\end{array}$ & $\begin{array}{c}\text { Solid } \\
\text { Waste } \\
\text { (Electricity) }\end{array}$ & $\begin{array}{c}\text { Solar } \\
\text { Electricity } \\
(5)\end{array}$ \\
\hline 1985 Model Year & & & & & & & & & \\
\hline Liquid Hydrogen ICE & 0.768 & 2.059 & 4.800 & 1.587 & 3.821 & 1.749 & 3. 718 & 5.948 & 7.826 \\
\hline Iron-Titanium Hydride ICE & 0.868 & 1.797 & 4.173 & 1. 382 & 3.326 & 1.523 & 3.236 & 5.178 & 6.813 \\
\hline Lead / Acid Battery & 0.690 & 2. 300 & 2. $7<9$ & 2. 184 & 2.184 & 1.001 & 2.694 & 3.405 & 4.480 \\
\hline $\begin{array}{l}\text { Nickel/Zine Battery } \\
1990 \text { Model Year }\end{array}$ & 0.557 & 1.856 & 2.219 & 1.763 & 1.763 & 0.308 & 1.718 & 2. 749 . & 3.617 \\
\hline Liquid Hydrogen ICE & 0.525 & 1.265 & 2.793 & 1.078 & 2.365 & 1.085 & 2. 305 & 3.688 & 4.853 \\
\hline Iron-Titanium Hydride ICE & 0.736 & 1.376 & 3.041 & 1.172 & 2.573 & 1.179 & 2. 506 & 4.010 & 5.277 \\
\hline Advanced Hydride ICE & 0.913 & 1.706 & .3 .773 & 1.454 & 3. 192 & 1.463 & 3. 109 & 4.975 & 6.546 \\
\hline $\begin{array}{l}\text { Zinc/Chlorine Hydrate } \\
\text { Battery } \\
2000 \text { Model Year }\end{array}$ & 0.521 & 1.735 & 1.951 & 1.649 & $1.649^{\circ}$ & 0.756 & 1.607 & 2.571 & 3. 383 \\
\hline Liquid Hydrogen ICE & 0.439 & 0.994 & $\begin{array}{r}1.892 \\
1.514\end{array}$ & 0.885 & 1.942 & 0.890 & 1.892 & 3.028 & 3.984 \\
\hline Advanced Hydride ICE & 0.768 & 1.372 & 2.6212 .093 & 1.223 & 2.685 & 1.231 & 2.615 & 4.185 & 5.506 \\
\hline $\begin{array}{l}\text { Lithium-Aluminum/Iron } \\
\text { Sulfide Battery }\end{array}$ & 0.256 & 0.852 & 0.790 & 0.810 & 0.810 & 0.372 & 0.790 & 1.263 & 1.662 \\
\hline
\end{tabular}

(1) Minimum Range $=85 \mathrm{mi}$ for hydrogen-powered vehicles. For battery-powered vehicles, minimum range of 64.2 to $111.1 \mathrm{mi}$ is established by power requirements, cycle life, and number of batteries needed to achieve vehicle lifetime mileage of $100,000 \mathrm{mi}$.

(2) Neglects storage capability in energy transportation.

${ }^{(3)}$ Terms in parentheses indicate initial energy conversion product. Where two energy products are indicated, the most efficient is chosen for each vehicle type.

(4) Nuclear electricity generation efficiencies in 2000 are assumed to be 0.40 (Simple Turbine. Cycle) and 0.50 (Bottoming Turbine Cycle).

(5) Solar energy conversion by a central receiver of reflected energy, with a steam turbine is assumed to have an efficiency of 0.19 . 
TABLE 20. COMPARISON OF KEY CHARACTERISTICS OF HYDROGEN-AND BATTERY - POWERED CARS

\begin{tabular}{|c|c|c|c|c|c|c|c|c|c|c|c|}
\hline \multirow{3}{*}{ Propuision System } & \multirow{3}{*}{$\begin{array}{l}\text { Design } \\
\text { Range } \\
\text { mi }\end{array}$} & \multirow{3}{*}{$\begin{array}{l}\text { Usefulness } \\
\text { \% of Days }\end{array}$} & \multirow{3}{*}{$\begin{array}{c}\text { Curb } \\
\text { Weight } \\
\text { lb }\end{array}$} & \multirow{3}{*}{$\begin{array}{l}\text { Total Cost } \\
\text { of } \\
\text { Ownership } \\
\mathrm{c} / \mathrm{mi}\end{array}$} & \multirow{3}{*}{$\begin{array}{l}\text { Vehicle } \\
\text { Input } \\
\text { Energy } \\
\text { kWl:/ni }\end{array}$} & \multirow{2}{*}{\multicolumn{2}{|c|}{$\begin{array}{c}\text { Source Energy/ } \\
\text { Vehicle Mile } \\
\mathrm{kWh} / \mathrm{mi}\end{array}$}} & \multirow{3}{*}{$\begin{array}{l}\text { Wheelbase } \\
\text { Increase } \\
\text { Over } \\
\text { Gasoline } \\
\text { ICE Car, } \\
\text { in. }\end{array}$} & \multicolumn{3}{|c|}{$\begin{array}{l}\text { Effects of Range } \\
\text { Increase to } 200 \mathrm{mi} \text {. }\end{array}$} \\
\hline & & & & & & & & & \multirow{2}{*}{$\begin{array}{l}\text { Curb Wt } \\
\text { Inczease } \\
\text { Ib }\end{array}$} & \multirow{2}{*}{$\begin{array}{l}\text { Ownership } \\
\text { Cost Increase } \\
\quad \xi / \mathrm{mi}\end{array}$} & \multirow{2}{*}{$\begin{array}{c}\text { Wheclbase } \\
\text { Increase } \\
\text { in. }\end{array}$} \\
\hline & & & & & & Coal & Nuclear & & & & \\
\hline 1985 Model Year & & & & & & & & & & & \\
\hline Liquid Hydrogen ICE & 85 & 95.1 & 2220 & 13.0 & 0.768 & 2.059 & 4.800 & 3.5 & 180 & 0.6 & 5.0 \\
\hline Iron-Titanium Hydride ICE & 85 & 95.1 & 2940 & 16.4 & 0.868 & 1.797 & $4.173^{\circ}$ & 4.8 & 2060 & 12.5 & 11.2 \\
\hline Lead/Acid Battery & 64.2 & 91.3 & 4718 & $18.1-21.5$ & 0.690 & 2.300 & 2.749 & 26.1 & \multicolumn{3}{|c|}{ Practizally Impossible } \\
\hline Nickel/Zinc Battery & 80.8 & 94.6 & 3499 & $17.8-21.6$ & 0.557 & 1.856 & 2.219 & 18. 4 & \multirow{2}{*}{\multicolumn{3}{|c|}{ Practically Impossible }} \\
\hline 1990 Model Year & & & & & & & & & & & \\
\hline Liquid Hydrogen ICE & 85 & 95.1 & 2100 & 12.2 & 0.525 & 1.265 & 2.793 & 2.3 & 1.10 & 0.5 & 3.3 \\
\hline tron-Titanium Hydride ICE & 85 & 95.1 & 2740 & $14.7-15.3$ & 0.736 & $1.370^{\circ}$ & 3.041 & 3.0 & 1245 & $6.4-7.7$ & 6.2 \\
\hline Advanced Hydride ICE & 85 & 95.1 & 2665 & 15. $3-15.4$ & 0.913 & 1.706 & 3.773 & 6.8 & 1615 & 6.0 & 12.5 \\
\hline $\begin{array}{l}\text { Zinc/Chlorine Hydrate } \\
\text { Battery }\end{array}$ & 111.1 & 96.5 & 3253 & $16.0-19.2$ & 0.521 & 1.735 & 1.951 & 23.1 & $3 x: 50$ & & +8 \\
\hline 2000 Model Year & & & & & & & & & & & \\
\hline Liquid Hydrogen ICE & 85 & 9.1 & 1895 & 11.7 & 0.439 & 0.994 & $\begin{array}{l}1.892- \\
1.514\end{array}$ & 2.0 & 95 & 0.5 & 2.7 \\
\hline Advanced Hydride ICE & 85 & 95.1 & 2340 & 14.4 & 0.768 & 1.372 & $\begin{array}{l}2.621- \\
2.093\end{array}$ & 5.5 & 300 & $4.9-5.0$ & 10.0 \\
\hline $\begin{array}{l}\text { Lithium-Aluminum/Iron } \\
\text { Sulfide Battery }\end{array}$ & 93.1 & 96.0 & 2149 & $11.6-13.6$ & 0.256 & 0.852 & $\begin{array}{c}0.790- \\
0.632\end{array}$ & 8.6 & 1570 & & 17 \\
\hline
\end{tabular}


horsepower, if desired. The need for heating of the liquid hydrogen to gasify or heat it provides an opportunity for a simple, lightweight air conditioning system.

8.2

\section{GASEOUS HYDROGEN - FUELED ICE CARS}

On balance, the iron-titanium alloy and advanced-magnesium alloy hydride systems are comparable, except for the better use of coal energy by iron-titanium vehicles. A simple, lightweight air conditioning system is also an inherent capability of the iron-titanium hydride system. Neither hydride system is competitive in the 2000 model year.

\section{3 \\ LEAD/ACID BATTERY-POWERED CAR}

This vehicle has the highest weight, greatest length, highest cost of ownership, lowest usefulness, highest source energy consumption, and is least adaptable to range extension.

8.4 NICKEL/ZINC BATTERY-POWERED CAR

This vehicle has a high weight, high length, high cost of ownership, and limited range extendability. However, it makes the best use of nuclear energy or other electric energy sources in 1985.

8.5 ZINC/CHLORINE HYDRATE BATTERY-POWERED CAR

This vehicle is characterized by high minimum range, weight, length, and cost of ownership. It has poor adaptability to range extension; however, it makes the best use of nuclear energy or electric energy sources in 1990. The vehicle accommodates a simple, lightweight air conditioning system option.

8.6

LITHIUM-A LUMINUM/IRON SULFLDE BATTERYPOWERED CAR

This vehicle is lightweight, moderate in length, low in ownership cost, and moderately adaptable to range extension. Its primary advantages are outstanding values of vehicle energy economy and utilization of all energy resources. 
The authors believe there is a generally uniform degree of optimism in the assumptions underlying the performance projected for each vehicle system considered in this report; however, the energy subsystem that probably appears most favorably treated is the model year 2000 lithiumaluminum/iron sulfide battery. Since no substantiation was offered for the battery's assumed 20-percent improvement of all major parameters relative to its 1990 counterpart, it was felt to be helpful to determine the impacts of more conservative assumptions. Therefore, the minimum range vehicle characteristics were obtained assuming that specific energy and specific power were improved only 10 percent (equivalent to a 10 -percent weight reduction), and that cycle life, energy efficiency, and specific cost remained the same. The following changes, relative to the tabulated model year 2000 lithium-aluminum/iron sulfide battery car, were determined:

1. A 19.3-percent increase in design range due to a 16.7percent reduction in cycle life

2.: A 42.7-percent increase in battery weight due to the increase in design range (item 1 ), to an 8.6-percent reduction in specific energy (watt hours per kilogram), and to a 13.1-percent increase in vehicle test weight (a 15.0-percent increase in curb weight)

3. A 31.2-percent increase in energy expenditure per unit distance due to the increases in design range and battery weight (items 1 and 2, respectively) and a 16.7-percent reduction in battery efficiency

4. A 3.4-percent increase (3.6 in.) in vehicle wheelbase due to the larger battery

5. A 15.3- to 17.4-percent increase in vehicle purchase price assuming the same battery specific costs ( $\$ 40$ and $\$ 60 / \mathrm{kWh})$

6. A 10- to 13-percent increase in cost of ownership (1.2£ to $1.8 \notin / \mathrm{mi}$ ) depending on battery specific cost and power cost.

Consequently, compared to the LSHV's and advanced hydride $\mathrm{GSHV}^{\prime}$ s of the year 2000, the conservative lithium-aluminum/iron sulfide EV is the heaviest, longest, most range sensitive, and possibly the most costly to own. However, it retains a significant advantage in input energy per mile, a pronounced advantage in the effective use of all electric energyi sources, and has an effectiveness between the values for the HV's in the use of coal resources. 
The EV's have an advantage over engine driven vehicles in the ease with which they can accommodate regenerative braking. Such braking is a practical means for increasing the minimum range by up to 8 to 13 percent depending upon the type of battery and the vehicle technology level (a function of the year). However, all EV's suffer substantial range loss (14 to 25 percent at minimum design range depending upon the same factors) at an accessory power level of $2.5 \mathrm{~kW}$, which could easily be required when heating is needed.

9. CONCLUSIONS

The low energy density of the battery and hydrogen energy storage systems considered in this study, compared to that of a gasoline-filled tank, leads to vehicle weights substantially greater than those of gasolinefueled vehicles of the same passenger capacity at all times. A portion of the increase in vehicle weight results from the increase in vehicle length required to accommodate the volume of the energy storage system. As design range is increased, vehicle weight for the options considered in the study increases much faster than is the case for a gasoline-fueled vehicle.

This study of four-passenger HV's and EV's has shown that, in the period from 1985 to 2000 , vehicles using liquid hydrogen energy storage would be the lightest, least range sensitive, and least expensive to own. Oniy the LSHV exhibits acceptable weight, length, and ownership cost increases at ranges over $200 \mathrm{mi}$. However, there is substantial concern for the safety aspects of the fueling, operation, and garaging of such vehicles. A great expansion of the infrastructure for producing, transmitting, and distributing liquid hydrogen would be needed with its associated high capital outlays and long time delays.

Although EV's at minimum design ranges are heavier than HV's, and therefore have higher road loads, their superior propulsion efficiencies result in the lowest vehicle input energy per mile of vehicle travel. For fossil energy sources, however, the overall efficiency of the logistic chains for supplying the cars with hydrogen (via gasification) or electricity strongly favors 
HV's. This study indicates that the combination of these two factors, which constitute the source energy expenditure per vehicle mile, shows decided advantages for HV's in 1985 and 1990 when making best use of fossil fuels. By 2000, however, short range EV's are projected to have such an advantage in input energy per mile that they will make better use of every energy resource than HV's. They will remain bulkier and more sensitive to requirements for increased range, speed, and acceleration.

The greatest drawback to the use of liquid hydrogen in cars is the uncertainty regarding safety hazards--not the commonly cited energy losses or added costs associated with liquefaction, which have been shown to be more than offset by the advantageous physical and performance characteristics of LSHV's. Additional study is warranted regarding the safe fueling, operation, garaging, and maintenance of such passenger cars; their susceptibility to damage in collisions; and the consequences of substantial liquid hydro-: gen spills under various degrees of fuel confinement.

There is not currently a hydrogen distribution infrastructure. Thus, unless a massive, government supported development of the needed facilities and network is undertaken, $\mathrm{HV}^{\prime} \mathrm{s}$ will not readily achieve widespread use. In this case, local or regional evolution of their capabilities, in the most economically favorable areas, is all that can be expected by the turn of the century. Developments in support of evidently ideal applications of liquid hydrogen, such as aircraft and possibly rail propulsion systems, could greatly affect hydrogen availability and cost.

The production of hydrogen by electrolysis, with efficiencies of 79 to 87 percent for industrial equipment or 60 to 75 percent estimated for residential units, is a less efficient (and more costly) use of electricity from any energy source than the efficient charging of EV's. However, other considerations, such as transmission of energy over long distances (more than $1000 \mathrm{mi}$ ) or over water from nuclear energy islands, or superior vehicle operating characteristics, could favor generation of electrolytic hydrogen over electricity. 
Delivery of hydrogen as a blend with natural gas would permit use of much of the extant transmission and distribution network. This system, however, is less homogeneous than the distribution of automobiles. Separation of hydrogen from the blend at the point of delivery can be effected with certain types of hydrides insensitive to contaminating gases (titaniumnickel alloys a re being studied by Daimler-Benz).

Electrically powered vehicles can be supported by an energy distribution system already in existence. Residential overnight charging of vehicle batteries can be done, in most cases, with no addition to power line or equipment capacity. This system offers powerplants an opportunity for improving load factor without addition of energy storage facilities since the automobile batteries can perform this function.

10.

\section{REFERENCES}

1. C. L. Tsaros, J. L. Arora, and K. B. Burnham, A Study of the Conversion of Coal to Hydrogen, Methane and Liquid Fuels for Aircraft, Final Report, Institute of Gas Technology, Chicago (June 1976), NASA Contract NAS1-13620.

2. H. G. Corneil, F. J. Heinzelmann, and E.W.S. Nicholson, Production Economics for Hydrogen, Ammonia and Methanol During the 1980-2000 Period, BNL-50663, Exxon Research and Engineering Co., Florham Park, N. J. (April 1977).

3. R: Wintrell, "The K-T Process: Koppers Commercially Proven Coal and Multi-Fuel Gasifier for Synthetic Gas Production in the Chemical and Fertilizer Industries," Paper Presented First World Hydrogen Energy Conference, Miami Beach, March 1976.

4. A. J. Konopka, et al., An Optimization Study of OTEC Delivery Systems Based on Chemical Energy Carriers, Final Report, AER-75-00033, Institute of Gas Technology, Chicago (May 1976) (ERDA Contract NSF-C1008).

5. W.J.D. Escher, T.D. Donakowski, and R. R. Tison, A Preliminary Systems Engineering Study of an Advanced Nuclear-Electrolytic Hydrogen Production Facility, Final Report, Institute of Gas Technology, Chicago (December 1975) (NASA Contract NAS8-30757).

6. Metals Week (16 May 1977).

7. American Metals Market (26 May 1977). 
8. H. Davitian, "Energy Carriers in Space Conditioning and Automotive Applications: A Comparison of Hydrogen, Methane, Methanol, and Electricity," Paper presented Ninth Intersociety Energy Conversion Engineering Conference, San Francisco, 26-30 August 1974.

9. F. Salzano, et al., Meeting at Brookhaven National Laboratory, Upton, New York, 13 December 1976.

10. D. Rohy, et al. , Meeting at Solar, Division of International Harvester, San Diego, California, 3 December 1976.

11. J. J. Reilly, R. H. Wiswall, and C. H. Waide, Motor Vehicle Storage of Hydrogen Using Metal Hydrides, TEC-75/001, Brookhaven National Laboratory, Upton, New York (October 1974).

12. R. B. 'Cole, "The Performance of Hydrogen-Fueled Reciprocating Engines," Vol. II, Paper presented Fourth International Symposium on Automotive Propulsion Systems, NATO/CCMS, Washington, D. C., April 1977.

13. R. E. Billings, A Hydrogen-Powered Mass Transit System, Billings Energy Research Corp., Provo, Utah (undated).

14. L. Bowen, "Hazards Associated with Hydrogen Fuel," Paper presented Eleven Intersociety Energy Conversion Engineering Conference, State Line, Nevada,. 12-17 September 1976.

15. R. L. Woolley, "Performance of a Hydrogen-Powered Transit Vehicle," Paper presented Eleventh Intersociety Energy Conversion Engineering Conference, State Line, Nevada, 12-17 September 1976.

16. C. J. Amato, "A Zinc-Chloride Battery - The Missing Link to a Practical Electric Car," SAE 730248, Paper presented International Automotive Engineering Congress, Society of Automotive Engineers, Detroit, Michigan, 8-12 January 1973.

17. A. A. Chilenskas, et al., "Design and Testing of Lithium/Iron Sulfide Batteries for Electric Vehicle Propulsion," Paper presented Fourth International Electric Vehicle Symposium, Dusseldorf, Germany, 31 August-2 September 1976.

18. N. P. Yao, A. A. Chilenskas, and P. A. Nelson, Meeting at Argonne National Laboratory, A rgonne, Illinois, 17 November 1976.

19. N. P. Yao, personal communication, Argonne National Laboratory, Argonne, Illinois (7 September 1977). 
20. A Program Plan for the Development of Electric Vehicle Batteries, Energy Research and Development Administration, Washington, D. C. , (October 1975).

21. A. A. Chilenskas, pérsonal communication, Argonne National Laboratory, Argonne, Illinois (7 September 1977).

22. W. Hamilton, Representative Future Batteries for Urban Electric Cars, Preliminary Report, IM-2049, General Research Corp., Santa Barbara, California (19 August 1976).

23. D. D. Davis, R. C. Epps, and R. A. Renner, "Theoretical Performance Upgrading of the E. V. A. Electric Vehicle by Use of a Flywheel/Battery Hybrid Power Train System," Vol. II, Paper presented Fourth International Symposium on Automotive Propulsion Systems, Washington, D. C., 17-22 April 1977.

24. D. D. Davis and R. C. Epps, "The Flywheel-Battery Hybrid Power System: A Concept to Improve Electric Vehicle Performance," Vol. II , Paper presented Fourth International Symposium on Automotive Propulsion Systems, Washington, D. C., 17-22 April 1977.

25. Electric Vehicle Test Procedure, SAE J227a, Society of Automotive Engineers, Inc., Warrendale, Pennsylvania (June 1976).

26. The Report by the Federal Task Force on Motor Vehicle Goals Beyond 1980, Vol. II, Task Force Report, Draft (2 September 1976).

27. Synthetic Liquid Fuels Development: Assessment of Critical Factors, Vo1. IV, ERDA 76-129/4, Energy Research and. Development Adminis tration, Washington, D.C. (May 1977).

28. H. J. Schwartz, "The Computer Simulation of Automobile Use Patterns for Defining Battery Requirements for Electric Cars," NASA TMX 71900, Paper presented Fourth International Electric Vehicle Symposium, Dusseldorf, Germany, 31 August-2 September 1976.

29. R. E. Balzhiser, "Fossil Fuel and Advanced Systems Division," EPRI Journal, $\underline{2}$ (6), 48-55 (August 1977).

30. Solar Thermal Conversion Mission Analysis. - Southwestern United States, Volume I: Summary Report, ATR-74(7417-16)-2, Energy and Resources Division, The Aerospace Corporation, El Segundo, California (January 1975).

31. Characterization and Applications Analys is of Energy Storage Systems, ATR-77(7538)-1, The Aerospace Corporation; El Segundo, California (April 1977) (National Science Foundation Grant No. AER 75-20387). 
32. E. E. Hughes, et al., Long Term Energy Alternative for Automotive Propulsion - Synthetic Fuel Versus Battery/Electric System, Final Report, Stanford Research Institute, Menlo Park, California (August 1976) (National Science Foundation Contract NSF-C915, Task Order No. 1$)$.

33. "New Zealand Study Favors $1400 \mathrm{MW}^{\prime} \mathrm{s}$ Combined Cycle, "Gas Turbine World (July 1977). 